UNIVERSIDADE DE BRASÍLIA

FACULDADE DE TECNOLOGIA

DEPARTAMENTO DE ENGENHARIA CIVIL E AMBIENTAL

\title{
FATORES VIÁRIOS QUE AFETAM A FISCALIZAÇÃO ELETRÔNICA DE AVANÇO DE SINAL VERMELHO EM INTERSEÇÕES URBANAS
}

\section{HUDSON CARRER PEREIRA}

ORIENTADOR: PAULO CESAR MARQUES DA SILVA

DISSERTAÇÃO DE MESTRADO EM TRANSPORTES

PUBLICAÇÃO: T.DM-002/2015

BRASÍLIA/DF: MARÇO - 2015 
UNIVERSIDADE DE BRASÍLIA

FACULDADE DE TECNOLOGIA

DEPARTAMENTO DE ENGENHARIA CIVIL E AMBIENTAL

FATORES VIÁRIOS QUE AFETAM A FISCALIZAÇÃO ELETRÔNICA DE AVANÇO DE SINAL VERMELHO EM INTERSEÇÕES URBANAS

\section{HUDSON CARRER PEREIRA}

DISSERTAÇÃO DE MESTRADO SUBMETIDA AO DEPARTAMENTO DE ENGENHARIA CIVIL E AMBIENTAL DA FACULDADE DE TECNOLOGIA DA UNIVERSIDADE DE BRASÍLIA COMO PARTE DOS REQUISITOS NECESSÁRIOS PARA A OBTENÇÃO DO GRAU DE MESTRE EM TRANSPORTES.

APROVADO POR:

Prof. Paulo Cesar Marques da Silva, PhD (UnB) (Orientador)

Prof ${ }^{a}$ Maria Alice Prudêncio Jacques, PhD (UnB) (Examinador Interno)

Prof. Artur Carlos de Morais, Dr. (Centro Universitário Estácio de Brasília) (Examinador Externo)

BRASÍLIA/DF, 24 DE MARÇO DE 2015 


\section{FICHA CATALOGRÁFICA}

PEREIRA, HUDSON CARRER

Fatores viários que afetam a fiscalização eletrônica de avanço de sinal vermelho em interseções urbanas. [Distrito Federal] 2015.

xiv, 120p., 210 x 297 mm (ENC/FT/UnB, Mestre, Transportes, 2015). Dissertação de Mestrado - Universidade de Brasília. Faculdade de Tecnologia.

Departamento de Engenharia Civil e Ambiental.

1. Fiscalização eletrônica

2. Interseções urbanas

3. Avanço de sinal vermelho

4. Redução de infrações

I. ENC/FT/UnB

II. Título (série)

\section{REFERÊNCIA BIBLIOGRÁFICA}

PEREIRA, H. C. (2015). Fatores viários que afetam a fiscalização eletrônica de avanço de sinal vermelho em interseções urbanas. Dissertação de Mestrado em Transportes, Publicação T.DM-002/2015, Departamento de Engenharia Civil e Ambiental, Universidade de Brasília, Brasília, DF, 120p.

\section{CESSÃO DE DIREITOS}

AUTOR: Hudson Carrer Pereira.

TÍTULO: Fatores viários que afetam a fiscalização eletrônica de avanço de sinal vermelho em interseções urbanas.

GRAU: Mestre

ANO: 2015

É concedida à Universidade de Brasília permissão para reproduzir cópias desta dissertação de mestrado e para emprestar ou vender tais cópias somente para propósitos acadêmicos e científicos. O autor reserva outros direitos de publicação e nenhuma parte dessa dissertação de mestrado pode ser reproduzida sem autorização por escrito do autor.

Hudson Carrer Pereira

hudcp@yahoo.com.br

CCSW 01, Lote 4, Bloco B, Apto 430

70.680-150 Brasília - DF - Brasil. 


\section{DEDICATÓRIA}

Aos meus pais Jorge e Celene, por todos os sacrifícios que passaram para criar e educar a mim e a meus irmãos. 


\section{AGRADECIMENTOS}

Agradeço a todos aqueles que, de alguma maneira, contribuíram para a realização deste trabalho. Em especial:

A Deus, pela oportunidade recebida.

Ao meu orientador, professor Paulo Cesar, por todos os ensinamentos transmitidos, pela dedicação e pela amizade.

A minha esposa Gisele, não só pelo incentivo nos bons e maus momentos, como também pela revisão do texto.

Aos meus pais Jorge e Celene e aos meus irmãos Robson e Karen, pelo carinho.

A todos os professores e funcionários do Departamento de Transportes da Universidade de Brasília, em especial aos professores Pastor e Maria Alice, pela contribuição à dissertação e pelo conhecimento repassado durante todo o curso, e à funcionária Lu, pela gentileza e atenção no atendimento aos alunos.

Aos companheiros do mestrado, pelos agradáveis momentos e experiências compartilhadas ao longo do curso.

Aos colegas do Detran/DF que me auxiliaram na obtenção e formatação dos dados, em especial ao Pedro, que me acompanhou nas visitas a campo.

Aos amigos João Carlos, Wanderlei, Felipe e Janneth pela contribuição ao trabalho e ajuda nos momentos de dificuldade.

Aos meus amigos de longa data, todo o meu apreço e gratidão. 
Expressar-se honestamente é não mentir para si mesmo.

Bruce Lee 


\title{
RESUMO
}

\section{FATORES VIÁRIOS QUE AFETAM A FISCALIZAÇÃO ELETRÔNICA DE AVANÇO DE SINAL VERMELHO EM INTERSEÇÕES URBANAS}

\author{
Autor: Hudson Carrer Pereira \\ Orientador: Paulo Cesar Marques da Silva \\ Programa de Pós-Graduação em Transportes, março de 2015
}

O presente trabalho trata da identificação e análise de fatores viários que afetam a fiscalização eletrônica de avanço de sinal vermelho em interseções urbanas para locais em que os equipamentos já estão instalados, com foco na redução do número de infrações. Como estudo de caso, foram analisadas cinco interseções no Distrito Federal, escolhidas a partir de dados obtidos no Sistema de Informações Georreferenciadas do Departamento de Trânsito do Distrito Federal.

Desse sistema foi extraído o índice de infração (relação entre o número de infrações aplicadas e o total de veículos) de cada equipamento, e a ferramenta estatística box plot foi utilizada para seleção das interseções críticas. Com base na legislação vigente e nas referências pesquisadas, pode-se concluir pela necessidade de estudos que visem à identificação de problemas e adoção das respectivas contramedidas de engenharia de operação do semáforo, de informação ao condutor e de melhorias físicas para avaliação da eficácia desses equipamentos. O cumprimento da legislação vigente na correta caracterização da infração de avanço de sinal e do tempo de retardo, juntamente com a atenção às recomendações técnicas de programação semafórica, constam das principais contribuições extraídas deste estudo de caso. Ademais, recomenda-se a adoção de metas para redução de infrações em cada local fiscalizado.

Palavras-chave: Fiscalização eletrônica, Interseções urbanas, Avanço de sinal vermelho, Redução de infrações. 


\title{
ABSTRACT \\ ROAD-RELATED FACTORS WHICH AFFECT THE ELECTRONIC ENFORCEMENT OF RED-LIGHT RUNNING IN URBAN INTERSECTIONS
}

\author{
Author: Hudson Carrer Pereira \\ Supervisor: Paulo Cesar Marques da Silva
}

Programa de Pós-Graduação em Transportes, March 2015

This dissertation identifies and analyzes road-related factors which affect the electronic enforcement of red-light running in urban intersections where the equipment is already installed, focusing particularly on reducing the number of traffic violations. The case study included the analysis of five intersections in Brazil's Federal District, selected from data gathered by the Geo-referenced Information System (GIS) of the Federal District's Department of Traffic.

The violation index of each equipment was extracted from GIS (relationship between number of violations applied and total number of vehicles) and statistical tool box plot was used to select critical intersections. Based on the current legislation and on the literature, the findings of this dissertation suggest the need for further studies that seek to identify problems and foster the use of the respective engineering countermeasures of traffic signal operation, driveroriented information, and physical improvements to assess the efficacy of the enforcement equipment. Conformity to the current legislation in the sense of correct characterization of red-light running and delay time, as well as compliance with technical recommendations of traffic signal programming, are among the main contributions of this case study. Furthermore, this work endorses the establishment of goals to reduce violations in each inspected location.

Keywords: Electronic enforcement, Urban intersection, Red-light running, Reduction of traffic violations. 
1 INTRODUÇÃO

1.1 DELIMITAÇÃO DO PROBLEMA ...................................................................... 6

1.2 HIPÓTESE ............................................................................................................................... 6

1.3 OBJETIVO ......................................................................................................... 7

1.4 JUSTIFICATIVA......................................................................................................... 7

1.5 METODOLOGIA _......................................................................................... 10

1.6 ESTRUTURA DA DISSERTAÇÃO ................................................................................ 11

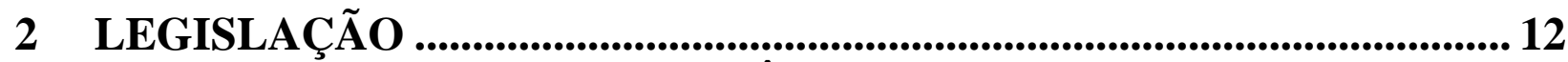

2.1 CONSELHO NACIONAL DE TRÂNSITO (CONTRAN) ……............................... 13

2.1.1 Medidores de velocidade................................................................................................ 17

2.1.2 Sistemas automáticos não metrológicos de fiscalização........................................... 19

2.1.3 Videomonitoramento................................................................................................ 21

2.2 DEPARTAMENTO NACIONAL DE TRÂNSITO (DENATRAN) ......................... 21

3 REFERENCIAL TEÓRICO ............................................................................ 24

3.1 CARACTERIZAÇÃO DO AVANÇO DE SINAL .................................................... 24

3.2 INSTALAÇÃO DE EQUIPAMENTOS DE FISCALIZAÇÃO ELETRÔNICA

DE AVANÇO DE SINAL ................................................................................................................ 27

3.2.1 Efeito colateral da utilização de equipamentos de fiscalização eletrônica para avanço de sinal vermelho ........................................................................................................ 30

3.2.2 Fiscalização eletrônica de avanço de sinal relacionada a acidentes de trânsito 32

3.2.3 Fiscalização eletrônica de avanço de sinal relacionada à redução de infrações 33

3.2.4 Fiscalização eletrônica conjunta de velocidade e avanço de sinal vermelho .... 35

3.2.5 Encerramento de programas de fiscalização eletrônica ........................................... 36

3.2.6 Índice de infrações......................................................................................................... 36

3.3 FATORES QUE INFLUENCIAM A REDUÇÃO DE INFRAÇÕES POR

AVANÇO DE SINAL ........................................................................................................................ 38

3.3.1 Fatores de exposiçãa.......................................................................................................... 39

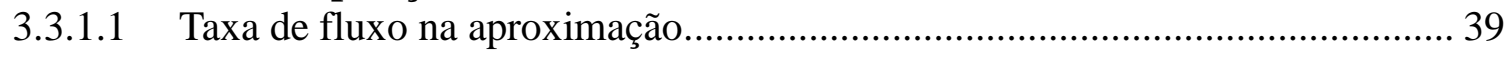

3.3.1.2 Número de ciclos do sinal ............................................................................ 40

3.3.1.3 Término de fase por tempo de verde máximo.................................................. 40

3.3.1.4 Taxa de fluxo na aproximação conflitante ....................................................... 41

3.3.2 Fatores de contribuição....................................................................................................... 41

3.3.2.1 Probabilidade de parar.............................................................................. 41

3.3.2.2 Duração do intervalo de amarelo .................................................................... 46

3.3.2.3 Duração do intervalo de vermelho geral ........................................................ 47

3.3.2.4 Tempo de entrada do condutor em conflito .................................................... 48

3.4 CONTRAMEDIDAS DE ENGENHARIA PARA REDUÇÃO DE INFRAÇÕES POR AVANÇO DE SINAL ............................................................................................................ 48

3.5 CAUSAS DE AVANÇO DE SINAL E CONTRAMEDIDAS.....................................55

3.6 CÁLCULO DO TEMPO DE RETARDO ...............................................................5 57

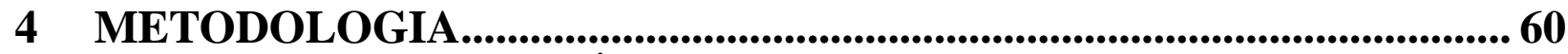

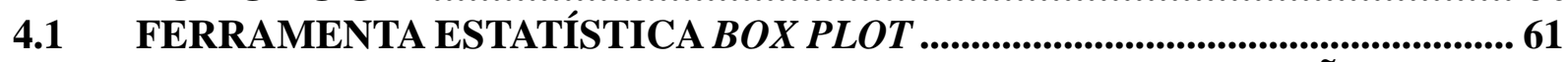

4.2 DADOS COLETADOS DOS EQUIPAMENTOS DE FISCALIZAÇÃO

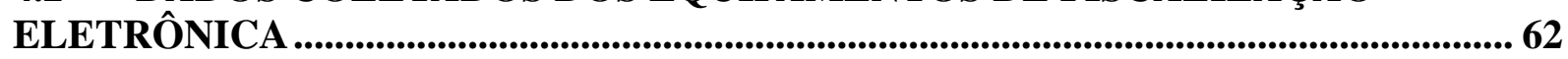

4.2.1 Identificação das interseções com maiores índices de infrações .......................... 62 
4.2.2 Seleção das interseções do estudo com base em relatório estatístico ................... 68

4.2.3 Autos de infração...................................................................................................................... 71

5 RESULTADOS E DISCUSSÃO

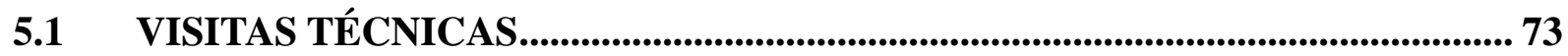

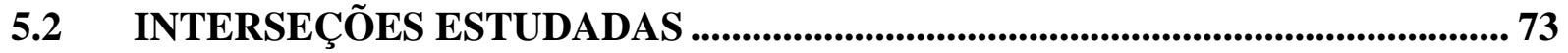

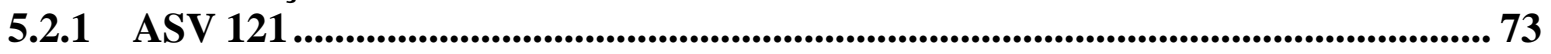

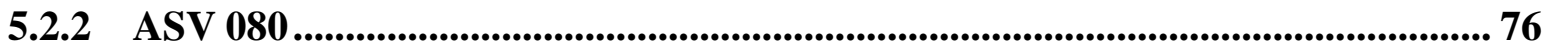

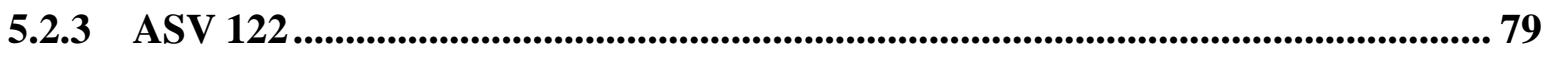

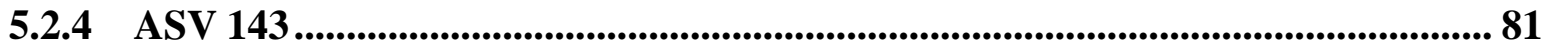

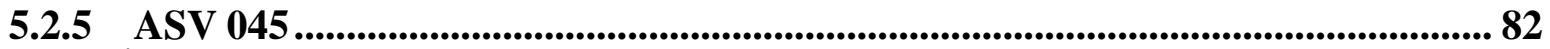

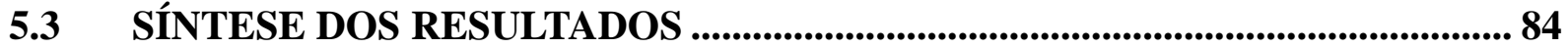

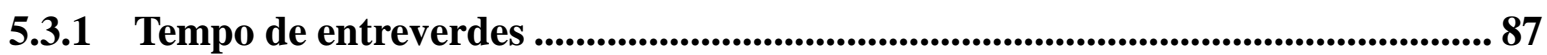

5.3.2 Tempo de retardo .......................................................................................... 89

5.3.3 Síntese dos principais problemas detectados ......................................................... 91

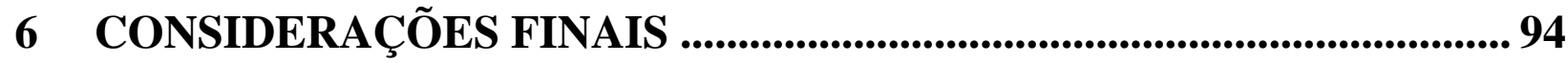

6.1 OBJETIVOS DO TRABALHO ..................................................................................... 94

6.2 USO DA FISCALIZAÇÃO ELETRÔNICA............................................................99

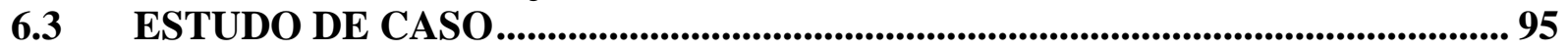

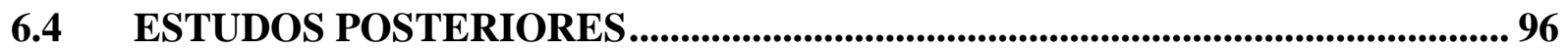

REFERÊNCIAS ................................................................................................... 97

APÊNDICES............................................................................................................. 102 


\section{LISTA DE TABELAS}

Tabela 1.1: Veículos acima da velocidade em equipamentos com e sem foto traseira

Tabela 1.2: Dados de movimentação do equipamento BDT 022 de janeiro/2011 a

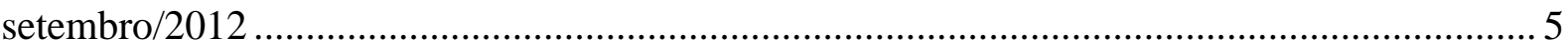

Tabela 1.3: Número de mortos e feridos por ASV nos Estados Unidos, de 2008 a 2012 .......... 8

Tabela 3.1: Taxas de ASV em diferentes cidades ................................................................... 37

Tabela 3.2: Tempo mínimo de amarelo em relação à velocidade regulamentada .................... 47

Tabela 4.1: Exemplo de dados de equipamentos de ASV referentes a novembro/2012 ..........63

Tabela 4.2: Relação mensal de infrações aplicadas pela quantidade de veículos, de

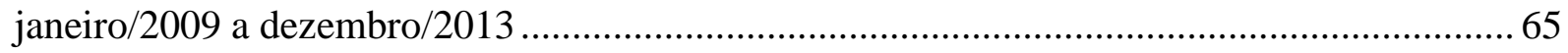

Tabela 4.3: Equipamentos de ASV em ordem decrescente de índice médio mensal de

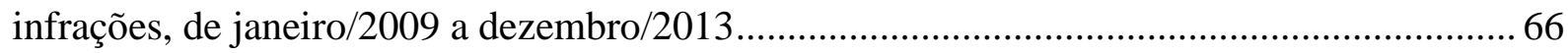

Tabela 4.4: Resumo das medidas estatísticas e valores obtidos com a ferramenta box plot, de janeiro/2009 a dezembro/2013

Tabela 4.5: Equipamentos considerados como pontos extremos e outliers, de janeiro/2009 a

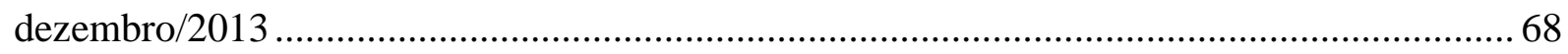

Tabela 4.6: Percentual de infrações por tipo, de abril/2013 a março/2014 ............................. 69

Tabela 4.7: Características das infrações, de abril/2013 a março/2014

Tabela 4.8: Tempo de passagem do veículo após o início do vermelho, fluxo a jusante e movimentos de conversão

Tabela 5.1: Características gerais de geometria, sinalização e elementos de programação semafórica .85

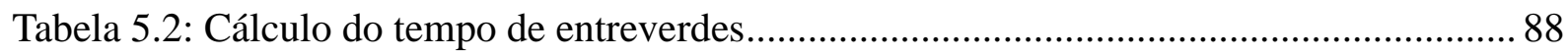

Tabela 5.3: Cálculo do tempo de retardo. 90 


\section{LISTA DE FIGURAS}

Figura 1.1: Número de óbitos em acidentes de trânsito no Brasil de 1996 a 2013 ................... 8

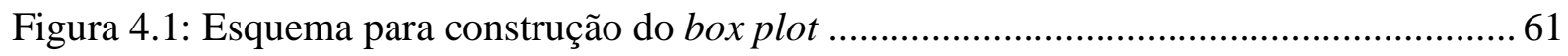

Figura 4.2: Veículo avançando o sinal após $36 \mathrm{~s}$ da indicação vermelha do semáforo ............. 72

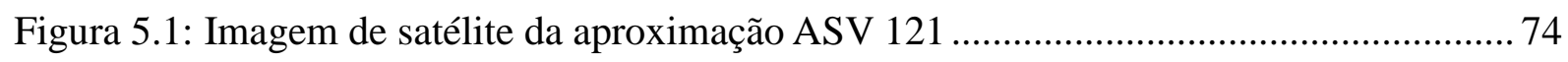

Figura 5.2: Vista da aproximação do equipamento ASV 121 ............................................... 74

Figura 5.3: Veículos estacionados em faixa de trânsito ao longo da via ................................. 75

Figura 5.4: Imagem captada pelo Google Street View, que destaca o posicionamento dos laços

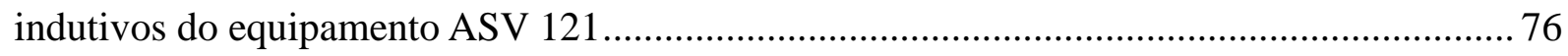

Figura 5.5: Imagem de satélite que retrata a aproximação ASV 080 e diagrama de estágios.. 77

Figura 5.6: Vista para a aproximação fiscalizada pelo equipamento ASV 080 ....................... 78

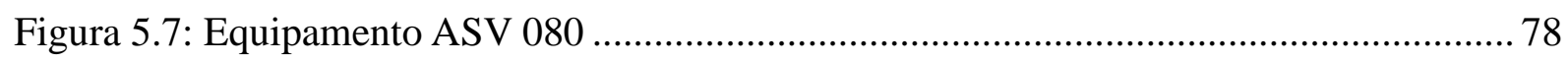

Figura 5.8: Vista da aproximação fiscalizada pelo equipamento ASV 080 ........................... 79

Figura 5.9: Imagem de satélite da aproximação fiscalizada pelo equipamento ASV 122 ....... 79

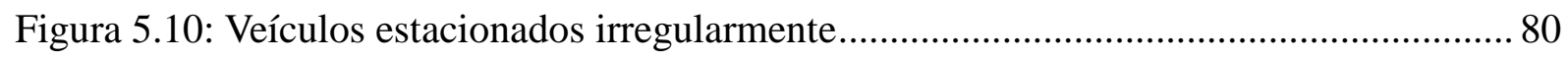

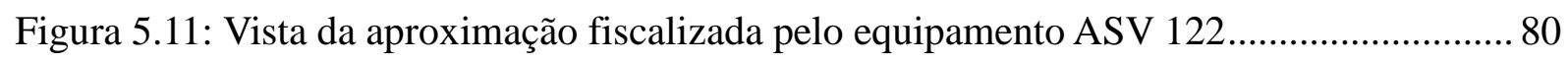

Figura 5.12: Imagem de satélite da aproximação fiscalizada pelo equipamento ASV 143 .....81

Figura 5.13: Vista da aproximação fiscalizada pelo equipamento ASV 143 .......................... 82

Figura 5.14: Imagem de satélite da aproximação fiscalizada pelo equipamento ASV 045 .....83

Figura 5.15: Vista da aproximação fiscalizada pelo equipamento ASV 045 .......................... 83

Figura 5.16: Imagem de satélite com indicação do trajeto de veículos em coordenação semafórica 84 


\section{LISTA DE QUADROS}

Quadro 2.1: Histórico das resoluções Contran relacionadas aos EFEs e aos objetivos do trabalho.

Quadro 2.2: Histórico das portarias do Denatran relacionadas aos EFEs e aos objetivos do trabalho

Quadro 3.1: Fatores de exposição e de contribuição relacionados ao ASV

Quadro 3.2: Fatores a serem considerados no processo de decisão .42

Quadro 3.3: Relação entre categorias de contramedidas e tipo de decisão do condutor 49

Quadro 3.4: Contramedidas de engenharia para redução de ASV 50

Quadro 3.5: Análise de contramedidas específicas de engenharia para redução de infrações por ASV

Quadro 3.6: Tipo de decisão do condutor e contramedidas de engenharia e fiscalização por causa possível de ASV .55

Quadro 5.1: Síntese dos problemas identificados e das respectivas contramedidas de engenharia 92 


\section{LISTA DE ABREVIAÇÕES}

ASV: avanço de sinal vermelho

Contran: Conselho Nacional de Trânsito

CTB: Código de Trânsito Brasileiro

Denatran: Departamento Nacional de Trânsito

Detran/DF: Departamento de Trânsito do Distrito Federal

DNIT: Departamento Nacional de Infraestrutura de Transportes

EFE: equipamento de fiscalização eletrônica

FHWA: Federal Highway Administration

LED: Light Emitting Diode

Inmetro: Instituto Nacional de Metrologia, Qualidade e Tecnologia

Ipea: Instituto de Pesquisa Econômica Aplicada

MUTCD: Manual on Uniform Traffic Control Devices

PSF: parada sobre a faixa de pedestre

SIG: Sistema de Informações Georreferenciadas

UPS: unidade padrão de severidade

VAL: velocidade acima do limite 


\section{INTRODUÇÃO}

A instalação de um equipamento de fiscalização eletrônica (EFE) objetiva o cumprimento, pelo condutor, do que indica a sinalização viária. Uma vez adequadas as condições da via e do veículo, o respeito à sinalização implicará trafegar em condições de segurança, tendo como consequência a redução da severidade e da quantidade de acidentes.

Por influenciar o comportamento do condutor para o cumprimento da legislação vigente e para a adoção de hábitos de respeito a outros usuários no trânsito, os EFEs fornecem grande potencial para a redução de acidentes, não só pela fiscalização em si, como também pela coleta de dados do fluxo de tráfego (média e variância da velocidade, quantidade e tipo de infrações, fluxo e infrações por tipo de veículo, hora-pico de veículos e de infrações etc.). Tais dados podem ser transformados em informação, norteando as ações da engenharia, da educação e da fiscalização de trânsito, seja para segurança, seja para fluidez.

O Código de Trânsito Brasileiro (CTB), instituído pela Lei Federal n ${ }^{\circ}$ 9.503, de 23 de setembro de 1997, dispõe, em seu Art. 280, § 2º, que a infração de trânsito deverá ser “comprovada por declaração da autoridade ou do agente da autoridade de trânsito, por aparelho eletrônico ou por equipamento audiovisual, reações químicas ou qualquer outro meio tecnologicamente disponível, previamente regulamentado pelo CONTRAN" [Conselho Nacional de Trânsito] (BRASIL, 1997, grifo nosso). De acordo com a legislação vigente, dentre os meios tecnologicamente disponíveis e as respectivas infrações fiscalizadas, tem-se:

- Videomonitoramento (equipamento audiovisual): restrito a estradas e rodovias, seu uso é regulamentado pela Resolução Contran nº 471/2013 (CONTRAN, 2013b); o equipamento fiscaliza o descumprimento de normas gerais de circulação e conduta detectadas on-line.

- Equipamentos metrológicos (aparelho eletrônico): medem a velocidade dos veículos e são utilizados para fiscalizar a infração prevista no Art. 218 do CTB - transitar em velocidade superior à máxima permitida para o local. É regulamentado pela Resolução Contran $n^{\circ}$ 396/2011 (CONTRAN, 2011).

- Sistemas automáticos não metrológicos de fiscalização (aparelho eletrônico): conforme a Portaria Denatran no 16/2004 (DENATRAN, 2004), Art. 2º é o conjunto constituído pelo instrumento ou equipamento de controle não metrológico, o módulo detector veicular e o 
dispositivo registrador de imagem, por processo químico ou digital, que não necessita da interferência do operador em qualquer das fases do seu funcionamento. Regulamentados pelas Resoluções Contran no 165/2004 (CONTRAN, 2004a), n 174/2005 (CONTRAN, 2005) e $n^{\circ} 458 / 2013$ (CONTRAN, 2013a), fiscalizam diversos tipos de infrações capituladas no CTB (BRASIL, 1997), quais sejam:

\section{Portaria Denatran $n^{\circ}$ 16/2004 (DENATRAN, 2004)}

- Avançar o sinal vermelho do semáforo (Art. 208);

- Parar o veículo sobre a faixa de pedestre na mudança de sinal luminoso (Art. 183);

- Transitar com o veículo em faixa ou pista regulamentada como de circulação exclusiva para determinado tipo de veículo (Art. 184, incisos I e II);

- Quando em movimento, não conservar o veículo na faixa a ele destinada pela sinalização de regulamentação (Art. 185, inciso I).

Portaria Denatran $n^{\circ}$ 27/2005 (DENATRAN, 2005)

- Transitar em locais e horários não permitidos pela regulamentação estabelecida pela autoridade competente para todos os tipos de veículos (Art. 187, inciso I).

\section{Portaria Denatran $n^{\circ}$ 263/2007 (DENATRAN, 2007)}

- Executar operação de retorno em locais proibidos pela sinalização (Art. 206, inciso I);

- Executar operação de conversão à direita ou à esquerda em locais proibidos pela sinalização (Art. 207).

Cabe esclarecer que os dispositivos ou equipamentos medidores de velocidade, com ou sem registrador de imagem, conforme a Resolução Contran n 396/2011 (CONTRAN, 2011), e os sistemas automáticos não metrológicos, com registrador de imagem, conforme a Resolução Contran n 458/2013 (CONTRAN, 2013a), são classificados pelos seguintes tipos:

I - Fixo: instalado em local definido e em caráter permanente;

II - Estático: instalado em veículo parado ou em suporte apropriado;

III - Móvel: em veículo em movimento, procedendo à fiscalização ao longo da via;

IV - Portátil: direcionado manualmente para o veículo-alvo. 
Em uso no Distrito Federal, os equipamentos eletrônicos fixos são empregados para a fiscalização de veículos que trafegam acima da velocidade (metrológicos); para avanço de sinal vermelho (ASV), parada sobre a faixa de pedestre (PSF), presença de automóveis em faixas exclusivas de ônibus e trânsito de caminhões em vias proibidas (não metrológicos); para videomonitoramento em estradas e rodovias.

O Departamento de Trânsito do Distrito Federal (Detran/DF), órgão executivo de trânsito com circunscrição em vias urbanas do Distrito Federal, iniciou a instalação dos EFEs em novembro de 1996. Atualmente conta com 143 controladores eletrônicos de velocidade, conhecidos como "pardais", e 104 redutores eletrônicos de velocidade (barreira ou lombada eletrônica).

Além desses equipamentos ao longo das vias, nas interseções urbanas, foco do estudo do presente trabalho, tem-se 123 equipamentos não metrológicos fixos que fiscalizam ASV e PSF, instalados juntamente com medidores de velocidade (equipamento metrológico), que fiscalizam a velocidade acima do limite (VAL).

Os dados registrados pelos EFEs em vias urbanas vêm sendo objeto de pesquisa da engenharia de trânsito do Detran/DF, e cabe citar aqui algumas pesquisas referentes ao tema. Pereira e Silva (2012) estudaram a influência do radar no comportamento de condutores em interseções semaforizadas. Ao comparar duas interseções com características geométricas e de tráfego semelhantes, diferenciadas apenas pela presença de EFE em uma delas, os autores observaram que a interseção com radar apresentou menor número de veículos avançando o sinal vermelho e menor tempo de passagem do último veículo pela linha de retenção após o tempo de amarelo do semáforo, porém com maior número de freadas bruscas (risco de colisões traseiras).

Na mesma linha, Pereira et al. (2014) analisaram a utilização de displays de velocidade em controladores eletrônicos de velocidade e concluíram que, nos locais com esses equipamentos, a média de infração por excesso de velocidade foi de quatro infrações para cada dez mil veículos. Nos locais onde não havia displays instalados, a média foi de dezessete infrações para cada dez mil veículos. 
Nos termos da Resolução Contran n 396/2011 (CONTRAN, 2011), esclarece-se que o uso de dispositivo que mostre aos condutores a velocidade medida (display) é obrigatório somente quando se emprega redutor eletrônico de velocidade (barreira eletrônica), não havendo menção a controladores eletrônicos de velocidade.

Pereira e Ayala (2011) estudaram quatro redutores eletrônicos de velocidade na Via LJ02, em Taguatinga-DF. Dois equipamentos (BDT 022 e BDT 023) registravam somente fotos dianteiras e os outros dois (LDT 013 e LDT 014), além de registrarem fotos dianteiras, contavam com câmera instalada em poste ostensivo para o registro de fotos traseiras.

Conforme pode ser visualizado na Tabela 1.1, os equipamentos com foto traseira registravam percentual de veículos com VAL muito menor que os equipamentos sem foto traseira.

Tabela 1.1: Veículos acima da velocidade em equipamentos com e sem foto traseira

\begin{tabular}{c|c|c|c|c}
\hline \multirow{2}{*}{ Média mensal } & \multicolumn{2}{|c|}{ Sem foto traseira } & \multicolumn{2}{c}{ Com foto traseira } \\
\cline { 2 - 5 } & BDT 022 & BDT 023 & LDT 013 & LDT 014 \\
\hline Acima da velocidade & 2.091 & 3.003 & 227 & 163 \\
\hline Total de veículos & 429.703 & 480.939 & 356.778 & 363.946 \\
\hline Percentual & $0,49 \%$ & $0,62 \%$ & $0,06 \%$ & $0,04 \%$ \\
\hline
\end{tabular}

Fonte: Sistema de Informações Georreferenciadas do Detran/DF (Sig-Detran/DF).

As fotos traseiras são importantes para o registro de infrações de motocicletas, pois esses veículos só possuem placa de identificação na parte de trás. Partindo-se da premissa de que os condutores de motocicletas notavam a presença do poste com câmera para registro de fotos traseiras dos veículos, em maio de 2012 foi solicitada a instalação de poste no equipamento BDT 022 para simular a fiscalização traseira (sem de fato estar funcionando, pois não constava do contrato), como tentativa de diminuir o número de veículos trafegando em VAL.

Ainda que a câmera não estivesse registrando as imagens traseiras dos veículos, pode-se perceber na Tabela 1.2 que o número de veículos trafegando acima da velocidade gradativamente diminuiu: a média de 49 veículos com VAL para cada dez mil veículos foi reduzida para oito veículos com VAL para cada dez mil veículos. O contrato de barreiras eletrônicas sem câmeras traseiras deixou de vigorar em outubro de 2012. 
Tabela 1.2: Dados de movimentação do equipamento BDT 022 de janeiro/2011 a setembro/2012

\begin{tabular}{|c|c|c|c|}
\hline Data & $\begin{array}{l}\text { Veículos acima } \\
\text { da velocidade }\end{array}$ & $\begin{array}{l}\text { Quantidade de } \\
\text { veículos }\end{array}$ & Porcentual \\
\hline Jan/11 & 2.381 & 379.130 & $0,63 \%$ \\
\hline Fev/11 & 1.978 & 367.095 & $0,54 \%$ \\
\hline Mar/11 & 1.922 & 411.355 & $0,47 \%$ \\
\hline Abr/11 & 1.926 & 413.104 & $0,47 \%$ \\
\hline Maio/11 & 2.142 & 432.161 & $0,50 \%$ \\
\hline Jun/11 & 2.239 & 432.661 & $0,52 \%$ \\
\hline $\mathrm{Jul} / 11$ & 2.328 & 422.505 & $0,55 \%$ \\
\hline Ago/11 & 2.496 & 454.588 & $0,55 \%$ \\
\hline Set/11 & 2.579 & 450.753 & $0,57 \%$ \\
\hline Out/11 & 2.330 & 454.643 & $0,51 \%$ \\
\hline Nov/11 & 2.127 & 451.783 & $0,47 \%$ \\
\hline Dez/11 & 2.232 & 478.028 & $0,47 \%$ \\
\hline Jan/12 & 1.989 & 428.504 & $0,46 \%$ \\
\hline Fev/12 & 1.576 & 419.770 & $0,38 \%$ \\
\hline Mar/12 & 1.648 & 458.395 & $0,36 \%$ \\
\hline $\mathrm{Abr} / 12$ & 1.566 & 420.769 & $0,37 \%$ \\
\hline Maio/12 & 753 & 464.589 & $0,16 \%$ \\
\hline Jun/12 & 245 & 445.045 & $0,06 \%$ \\
\hline $\mathrm{Jul} / 12$ & 265 & 439.248 & $0,06 \%$ \\
\hline Ago/12 & 246 & 462.989 & $0,05 \%$ \\
\hline Set/12 & 186 & 413.511 & $0,04 \%$ \\
\hline Média Jan/11 a Abr/12 & 2.091 & 433.363 & $0,49 \%$ \\
\hline Média Maio/12 a Set/12 & 339 & 445.076 & $0,08 \%$ \\
\hline
\end{tabular}

Fonte: PEREIRA e AYALA (2011).

Registra-se que, tanto ao longo das faixas de rolamento como nas interseções, os EFEs estão instalados em locais que garantam sua visibilidade pelos condutores, conforme estabelece o Art. 4 ${ }^{\circ}, \S 2^{\circ}$, da Resolução Contran $n^{\text {o }}$ 396/2011 (CONTRAN, 2011). A exigência de visibilidade serve somente para os equipamentos metrológicos medidores de velocidade do tipo fixo.

No caso das interseções urbanas do Distrito Federal, uma vez que os equipamentos metrológicos operam juntamente com os não metrológicos, ambos oferecem visibilidade ao condutor.

Diante da notada influência dos EFEs no comportamento dos condutores observada nos estudos supracitados, cujo foco era a segurança viária, este trabalho desenvolveu-se com base na constatação de que, mesmo diante da ostensividade dos EFEs, algumas interseções 
apresentavam índices de infrações (quantidade total de infrações em relação à quantidade de veículos) bem superiores aos das demais.

De forma a entender essa questão, com base na literatura e em visitas técnicas aos locais críticos, buscou-se identificar e analisar os fatores que influenciam o cometimento de infrações em interseções, limitadas neste estudo ao ASV. O objetivo consistiu em fornecer subsídios ao órgão de trânsito com circunscrição sobre a via para instalação e verificação da eficácia do EFE na redução de infrações.

\subsection{DELIMITAÇÃO DO PROBLEMA}

O presente trabalho busca entender por que algumas interseções localizadas em vias urbanas do Distrito Federal possuem elevados índices de infrações de ASV em comparação com outras interseções, mesmo diante da ostensividade dos EFEs.

Ainda que haja influência do medidor de velocidade no fluxo de tráfego em relação ao equipamento não metrológico de ASV, por estarem instalados juntos nas interseções urbanas do Distrito Federal, as interseções estudadas, bem como as referências levantadas, focam o problema do ASV.

As interseções foram selecionadas com base no índice total de infrações (relação entre a somatória das infrações de ASV, PSF e VAL e o número de veículos) em dados do órgão de trânsito no período de janeiro de 2009 a dezembro de 2013, com aplicação da ferramenta estatística box plot.

Dentre as interseções com índices de infrações acima do limite superior (pontos extremos e discrepantes ou outliers), foram estudadas somente aquelas em que $100 \%$ do total de infrações correspondiam à infração de ASV, conforme dados disponíveis no período de abril de 2013 a março de 2014. Tais dados foram obtidos nas empresas prestadoras dos serviços de fiscalização eletrônica.

\subsection{HIPÓTESE}

Adotando-se como premissa que os condutores de veículos motorizados do Distrito Federal possuem um comportamento padrão perante os EFEs, a hipótese a ser testada é a de que, nas 
interseções selecionadas com base no índice de infrações aplicadas, há fatores específicos a serem estudados que dificultam aos condutores a obediência à fiscalização eletrônica e que são mais "fortes" que os impactos previstos por essa fiscalização. Tais impactos consistem em penalizar monetariamente e colocar em risco a prerrogativa de dirigir, afetando negativamente a eficácia desses equipamentos.

\subsection{OBJETIVO}

Este trabalho tem por objetivo identificar e analisar os fatores viários que afetam o desrespeito à sinalização de trânsito em avançar o sinal vermelho do semáforo em locais onde a fiscalização eletrônica já está instalada, identificando as respectivas contramedidas de engenharia com foco na redução do número de infrações.

\subsection{JUSTIFICATIVA}

Segundo o CTB (BRASIL, 1997), em seu Art. 1º § 2º “o trânsito, em condições seguras, é um direito de todos e dever dos órgãos e entidades componentes do Sistema Nacional de Trânsito, a estes cabendo, no âmbito das respectivas competências, adotar as medidas destinadas a assegurar esse direito". Orientada por essa concepção, a Resolução Contran no 166/2004 ${ }^{1}$ (CONTRAN, 2004b), que aprova as diretrizes da Política Nacional de Trânsito, apresenta dados da segurança no trânsito brasileiro com base no ano de 2003. De acordo com a supracitada resolução, a cada ano mais de 33 mil pessoas são mortas e cerca de 400 mil tornam-se feridas ou inválidas, resultado de cerca de 350 mil acidentes de trânsito.

Em 2 de março de 2010, a Assembleia-Geral da Organização das Nações Unidas (ONU) decretou a Década Mundial de Ação pela Segurança no Trânsito 2011-2020, com o objetivo de conter e reverter a tendência crescente de mortes e incapacidades físicas por acidentes rodoviários.

De acordo com o Plano Nacional de Redução de Acidentes e Segurança Viária para a Década 2011-2020 (DENATRAN, 2010b), com relação às campanhas fiscalizatórias de âmbito nacional, tem-se como meta física a redução de $50 \%$ do índice de fatalidade dos acidentes de trânsito no decorrer da década em questão.

\footnotetext{
${ }^{1}$ Revogada em 6 de janeiro de 2015 pela Resolução Contran no 514, de 18 de dezembro de 2014.
} 
Ainda que a Resolução Contran n 166/2004 (CONTRAN, 2004b), além de outros textos normativos que tratam da segurança no trânsito, possibilite aos órgãos executivos de trânsito de todo o país nortear o planejamento de suas ações, a Figura 1.1 revela que, de 2000 a 2012, houve uma tendência crescente no número de óbitos em acidentes de trânsito no Brasil, com exceção de 2009. Em 2013 houve uma queda de aproximadamente 10\% no número de mortes em relação a 2012 (ano de maior número de mortes da série histórica), porém ainda em patamar bastante elevado.

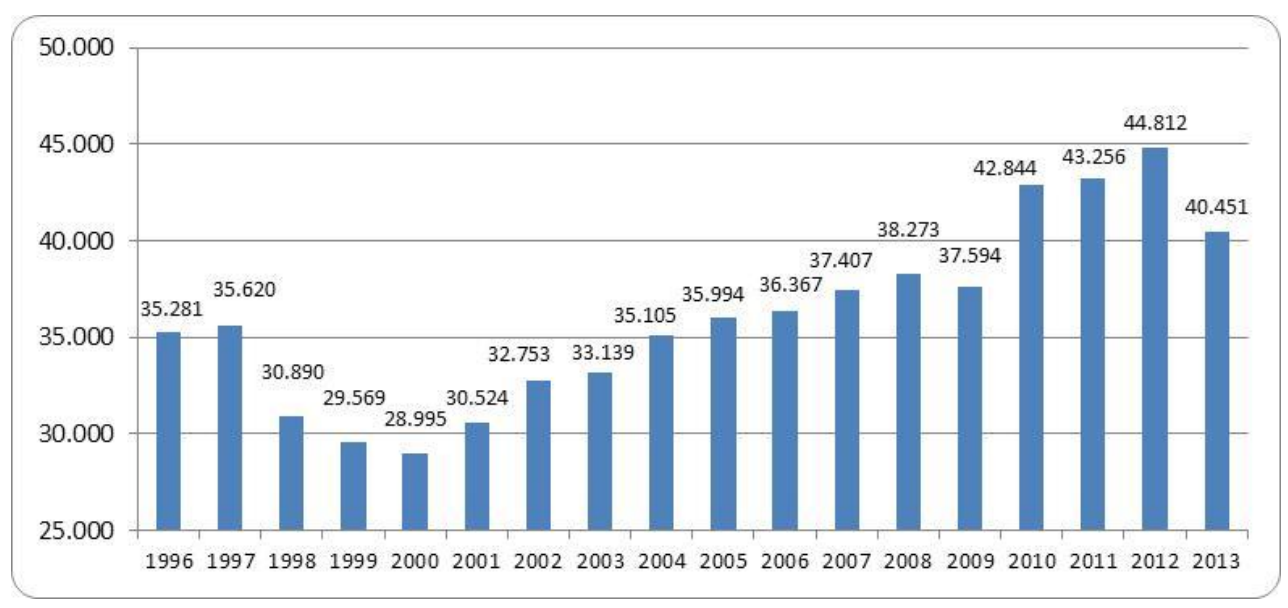

Figura 1.1: Número de óbitos em acidentes de trânsito no Brasil de 1996 a 2013

Fonte: MINISTÉRIO DA SAÚDE (2014).

Nos Estados Unidos, diversos estudos citam os números de mortos e feridos em decorrência especificamente de ASV, que podem ser visualizados na Tabela 1.3.

Tabela 1.3: Número de mortos e feridos por ASV nos Estados Unidos, de 2008 a 2012

\begin{tabular}{c|c|c|c}
\hline Ano & Mortos & Feridos & Estudo \\
\hline 2008 & 760 & 165.000 & USDOT (2012 apud Pulugurtha e Otturu, 2014) \\
\hline 2009 & 676 & 130.000 & FHWA (2011 apud Hallmark, Oneyear e McDonald, 2012) \\
\hline 2011 & 714 & 118.000 & IIHS (2013 apud McCartt e Hu, 2014) \\
\hline 2012 & 683 & 133.000 & Insurance Institute for Highway Safety [2013?] \\
\hline
\end{tabular}

Fonte: Elaborado pelo autor, 2014.

De acordo com o Insurance Institute for Highway Safety (2013 apud McCARTT e HU, 2014), mais da metade das mortes em 2011 eram de pedestres, ciclistas e ocupantes de outros veículos atingidos por condutores que avançaram o sinal vermelho. Retting, Ferguson e Farmer (2007) revelaram que, em 2005, cerca de metade dos mortos eram pedestres e 
ocupantes de outros veículos que foram atingidos por condutores que avançaram o sinal vermelho.

Avançar o sinal vermelho do semáforo é uma infração capitulada no Art. 208 do CTB (BRASIL, 1997) como gravíssima, e os acidentes relacionados a esse tipo de infração são pouco frequentes se comparados a outros tipos, porém têm alto grau de severidade.

Em geral, os estudos relacionados ao uso de EFEs para a fiscalização de ASV identificam, após a instalação do equipamento, uma diminuição no número de colisões em ângulo reto e um aumento no número de colisões traseiras, que são de menor gravidade (BONNESON, ZIMMERMAN e BREWER, 2002; RETTING, FERGUSON e FARMER, 2007; PAUW et al., 2014b; HELAY et al., 2008 apud VANLAAR, ROBERTSON e MARCOUX, 2014; COUNCIL et al., 2005 apud VANLAAR, ROBERTSON e MARCOUX, 2014).

Vanlaar, Robertson e Marcoux (2014) avaliaram fiscalização eletrônica de velocidade e ASV em Winnipeg, no Canadá. Concluíram que, enquanto a maioria dos estudos revelam uma redução global no excesso de velocidade, no ASV e nos acidentes associados, alguns não encontraram nenhuma melhoria significativa (ANDREASSEN, 1995; BURKEY e OBENG, 2004 apud VANLAAR, ROBERTSON e MARCOUX, 2014) ou encontraram resultados que sugerem que a fiscalização eletrônica é efetiva somente em alguns locais ou sob certas condições e que mais pesquisas são necessárias para entender melhor o impacto da fiscalização eletrônica e como essa medida pode ser mais bem empregada (ERKE, 2009; GARBER et al., 2007; KENT et al., 1997 apud VANLAAR, ROBERTSON e MARCOUX, 2014).

Além da quantidade de mortos e feridos no trânsito, fatores econômicos também trazem à tona a importância de estudos que possam reduzir a quantidade e a severidade dos acidentes. Utilizando a metodologia do Instituto de Pesquisa Econômica Aplicada (Ipea) com base nos dados de acidentes fatais e de feridos no Distrito Federal registrados pelo Detran/DF, Pereira et al. (2013) calcularam o custo da externalidade acidente de trânsito. Estimaram, para valores de março de 2013, a quantia de 370 milhões de reais por ano, considerando o período de 2000 a 2011. 
Outro aspecto ligado ao tema e presente na Resolução Contran n ${ }^{\text {1 }}$ 166/2004 (CONTRAN, 2004b) é que a arrecadação financeira resultante das multas seja desejavelmente decrescente. Assim, estudos que busquem reduzir as infrações de trânsito e, consequentemente, os acidentes podem contribuir para a maior aceitação desses equipamentos pela sociedade.

Bonneson, Zimmerman e Brewer (2002) analisaram a relação entre a taxa de acidentes e a taxa de ASV em vinte aproximações de interseções nos Estados Unidos. O estudo revelou que uma diminuição de 50\% na frequência de ASV produz uma redução de $25 \%$ nos acidentes.

Com relação à frequência das infrações de $\mathrm{ASV}$, estudos relatam que se trata de um evento comum (RETTING et al., 1999 apud McCARTT e HU, 2014; HILL e LINDLY, 2003 apud McCARTT e HU, 2014). Conforme a AAA Foundation for Traffic Safety (2012 apud McCARTT e HU, 2014), em uma pesquisa telefônica realizada em todo o território dos Estados Unidos em 2011, 94\% dos condutores consideram inaceitável avançar o sinal vermelho se é possível parar com segurança, mas $37 \%$ afirmaram tê-lo feito nos últimos trinta dias.

Do ponto de vista do condutor que recebe a notificação de infração, o processamento de infrações gera repercussões importantes na vida do indivíduo, como estabelece o Art. 256 do CTB (BRASIL, 1997): advertência por escrito, multa, suspensão do direito de dirigir, apreensão do veículo, cassação da Carteira Nacional de Habilitação, cassação da Permissão para Dirigir e frequência obrigatória em curso de reciclagem.

\subsection{METODOLOGIA}

De modo a identificar os fatores a serem considerados na instalação e na avaliação da eficácia de EFEs em interseções para infração de ASV, a revisão da literatura observou os requisitos legais com base no CTB (BRASIL, 1997) e suas alterações, nas resoluções do Conselho Nacional de Trânsito (Contran) e nas portarias do Departamento Nacional de Trânsito (Denatran) e a literatura técnica incluiu manuais e artigos para redução do número de infrações de ASV e, subsidiariamente, artigos relacionados à redução de acidentes por ASV. 
Os fatores identificados na literatura permitiram o desenvolvimento de um procedimento para o estudo das interseções fiscalizadas com base no índice de infrações de ASV. Os dados utilizados foram coletados junto ao órgão de trânsito e à empresa prestadora do serviço.

Durante as visitas técnicas foram realizadas filmagens, fotografias, medições do tempo do semáforo e medições físicas da interseção para o cálculo do tempo de retardo e de entreverdes, de modo a possibilitar a avaliação dos fatores que afetam o ASV e indicar as respectivas contramedidas de engenharia envolvendo a operação do semáforo, a informação ao condutor e melhorias físicas.

\subsection{ESTRUTURA DA DISSERTAÇÃO}

O presente capítulo é composto por introdução, delimitação do problema, hipótese, objetivos, justificativa, metodologia e estrutura da dissertação.

O Capítulo 2 dedica-se a explanar e analisar a legislação vigente sobre os EFEs de forma ampla, focando em seguida nos equipamentos não metrológicos para fiscalização da infração de ASV.

O Capítulo 3 apresenta as referências sobre o tema, debatendo estudos sobre a instalação e avaliação da eficácia dos EFEs para captar ASV, a identificação dos fatores que afetam acidentes e a quantidade de infrações relacionadas ao tipo ASV, com as respectivas contramedidas de engenharia e o cálculo do tempo de retardo.

O Capítulo 4 descreve o procedimento adotado para atingir os objetivos do trabalho.

O Capítulo 5 traz os resultados obtidos para as interseções estudadas, discorrendo sobre os fatores que explicam o alto índice de infrações nesses locais e que devem ser considerados na instalação e avaliação da eficácia dos equipamentos.

O Capítulo 6 traz as considerações finais e propostas para estudos posteriores. 


\section{LEGISLAÇÃo}

Conforme o Art. 12 da Lei ${ }^{\circ}$ 9.503, de 23 de setembro de 1997, que instituiu o CTB, compete ao Contran:

I - estabelecer as normas regulamentares referidas neste Código e as diretrizes da Política Nacional de Trânsito;

$[\ldots]$

VII - zelar pela uniformidade e cumprimento das normas contidas neste Código e nas resoluções complementares [...]. (BRASIL, 1997)

Com relação aos EFEs, a referida lei, em seu Art. 280, § $2^{\circ}$, dispõe:

Art. 280. Ocorrendo infração prevista na legislação de trânsito, lavrar-se-á auto de infração, do qual constará:

[...]

$\S 2^{\circ} \mathrm{A}$ infração deverá ser comprovada por declaração da autoridade ou do agente da autoridade de trânsito, por aparelho eletrônico ou por equipamento audiovisual, reações químicas ou qualquer outro meio tecnologicamente disponível, previamente regulamentado pelo CONTRAN. (BRASIL, 1997, grifo nosso)

O inciso II do Art. $2^{\circ}$ da Resolução Contran $n^{\circ} 165$, de 10 de setembro de 2004, estabelece:

Art. $2^{\circ}$. O sistema automático não metrológico de fiscalização deve:

$[\ldots]$

II - atender aos requisitos específicos mínimos para cada infração a ser detectada, estabelecidos pelo órgão máximo executivo de trânsito da União.

(CONTRAN, 2004a)

O Art. 19 do CTB dispõe que compete ao órgão máximo executivo de trânsito da União:

I - cumprir e fazer cumprir a legislação de trânsito e a execução das normas e diretrizes estabelecidas pelo CONTRAN, no âmbito de suas atribuições;

$[\ldots]$

XVIII - elaborar, juntamente com os demais órgãos e entidades do Sistema Nacional de Trânsito, e submeter à aprovação do CONTRAN, a complementação ou alteração da sinalização e dos dispositivos e equipamentos de trânsito;

XIX - organizar, elaborar, complementar e alterar os manuais e normas de projetos de implementação da sinalização, dos dispositivos e equipamentos de trânsito aprovados pelo CONTRAN; [...]. (BRASIL, 1997) 


\subsection{CONSELHO NACIONAL DE TRÂNSITO (CONTRAN)}

Com base nos artigos supracitados do CTB (BRASIL, 1997), o Contran vem legislando, por meio de resoluções e deliberações, sobre a utilização de meio eletrônico para fiscalização do trânsito. O histórico de resoluções pode ser visualizado no Quadro 2.1.

Quadro 2.1: Histórico das resoluções Contran relacionadas aos EFEs e aos objetivos do trabalho

\begin{tabular}{|c|c|}
\hline $\begin{array}{l}\text { Resolução } \\
\text { Contran }\end{array}$ & Assunto e Situação \\
\hline 23/1998 & $\begin{array}{l}\text { Define e estabelece os requisitos mínimos necessários para autorização e } \\
\text { instalação de instrumentos eletrônicos de medição de velocidade de } \\
\text { operação autônoma. Revogada pela Resolução Contran } n^{\circ} 141 / 2002 \text {. }\end{array}$ \\
\hline $79 / 1998$ & $\begin{array}{l}\text { Estabelece a sinalização indicativa de fiscalização. Revogada pela Resolução } \\
\text { Contran } n^{\circ} 141 / 2002 \text {. }\end{array}$ \\
\hline $86 / 1999$ & $\begin{array}{l}\text { Trata da utilização do radar portátil avaliador de velocidade pela fiscalização } \\
\text { de trânsito. Revogada pela Resolução Contran no } 141 / 2002 \text {. }\end{array}$ \\
\hline $111 / 2000$ & $\begin{array}{l}\text { Prorroga o prazo estabelecido no Art. } 3^{\circ} \text { da Resolução Contran n }{ }^{\circ} 79 / 1998 . \\
\text { Extinta. }\end{array}$ \\
\hline $118 / 2000$ & $\begin{array}{l}\text { Prorroga o prazo estabelecido no Art. } 3^{\circ} \text { da Resolução Contran } n^{\circ} 79 / 1998 . \\
\text { Revogada. }\end{array}$ \\
\hline $125 / 2001$ & $\begin{array}{l}\text { Prorroga o prazo estabelecido no Art. } 3^{\circ} \text { da Resolução Contran } n^{\circ} 79 / 1998 . \\
\text { Revogada. }\end{array}$ \\
\hline $131 / 2002$ & $\begin{array}{l}\text { Revogada pela Deliberação Contran } n^{\circ} 34 \text {. Declarada nula pela Resolução } \\
\text { Contran } n^{\circ} 140 / 2003 \text {. }\end{array}$ \\
\hline $136 / 2002$ & Dispõe sobre os valores das multas de infração de trânsito. Em vigor. \\
\hline $140 / 2002$ & $\begin{array}{l}\text { Declara a nulidade da Resolução Contran } n^{\circ} 131 / 2002 \text { e da Deliberação } n^{\circ} \\
\text { 34/2002. Em vigor. }\end{array}$ \\
\hline $141 / 2002$ & $\begin{array}{l}\text { Dispõe sobre o uso, a localização, a instalação e a operação de aparelho, de } \\
\text { equipamento ou de qualquer outro meio tecnológico para auxiliar na gestão } \\
\text { do trânsito e dá outras providências. Revogada pela Resolução Contran } \text { n }^{\circ} \\
146 / 2003 \text {. }\end{array}$ \\
\hline $146 / 2003$ & $\begin{array}{l}\text { Dispõe sobre requisitos técnicos mínimos para a fiscalização da velocidade } \\
\text { de veículos automotores, reboques e semirreboques, conforme o CTB. } \\
\text { Revoga a Resolução Contran } n^{\circ} 141 / 2002 \text {. Alterada pelas Resoluções } \\
\text { Contran } n^{\text {o }} 165 / 2004,214 / 2006 \text { e } 340 / 2010 \text {. Revogada pela Resolução } \\
\text { Contran } n^{\circ} 396 / 2011 \text {. }\end{array}$ \\
\hline $149 / 2003$ & $\begin{array}{l}\text { Dispõe sobre uniformização do procedimento administrativo da lavratura do } \\
\text { auto de infração, da expedição da notificação da autuação e da notificação da } \\
\text { penalidade de multa e de advertência por infrações de responsabilidade do } \\
\text { proprietário e do condutor do veículo e da identificação do condutor infrator. } \\
\text { Alterada pela Resolução Contran } \mathrm{n}^{\circ} 156 / 2004 \text {. Em vigor até o dia } 1^{\circ} \text { de julho } \\
\text { de } 2013 \text {, data em que entrará em vigor a Resolução Contran } \mathrm{n}^{\circ} 404 / 2012 \text {. }\end{array}$ \\
\hline $156 / 2004$ & $\begin{array}{l}\text { Dispõe sobre a alteração do prazo estabelecido no Art. } 14 \text { da Resolução } \\
\text { Contran } n^{\circ} 149 / 2003 \text {. Extinta pelo cumprimento de seu prazo. }\end{array}$ \\
\hline $162 / 2004$ & $\begin{array}{l}\text { Dispõe sobre a alteração do prazo estabelecido no Art. } 8^{\circ} \text { da Resolução } \\
\text { Contran } n^{\circ} 151 / 2003 \text {. Extinta pelo cumprimento de seu prazo. }\end{array}$ \\
\hline
\end{tabular}


Quadro 2.1: Continuação

\begin{tabular}{|c|c|}
\hline $\begin{array}{c}\text { Resoluçãa } \\
\text { Contran }\end{array}$ & Assunto e Situação \\
\hline $165 / 2004$ & $\begin{array}{l}\text { Regulamenta a utilização de sistemas automáticos não metrológicos de } \\
\text { fiscalização, nos termos do } \S 2^{\circ} \text { do artigo } 280 \text { do CTB. Revoga o Art. } 6^{\circ} \text { da } \\
\text { Resolução Contran } n^{\circ} 146 / 2003 \text {. Alterada pela Resolução Contran } n^{\circ} \\
174 / 2005 \text { e pela Resolução Contran } n^{\circ} 458 / 2013 \text {. Em vigor. }\end{array}$ \\
\hline $171 / 2005$ & $\begin{array}{l}\text { Dispõe sobre a utilização de sistemas automáticos não metrológicos de } \\
\text { fiscalização, nos termos do } \S 2^{\circ} \text { do Art. } 280 \text { do CTB. Revogada pela } \\
\text { Resolução Contran } n^{\circ} 174 / 2005 \text {. }\end{array}$ \\
\hline $174 / 2005$ & $\begin{array}{l}\text { Altera e esclarece dispositivos da Resolução Contran } n^{\circ} 165 / 2004 \text {, que trata } \\
\text { da regulamentação da utilização de sistemas automáticos não metrológicos } \\
\text { de fiscalização, nos termos do } \$ 2^{\circ} \text { do Art. } 280 \text { do CTB. Revoga a Resolução } \\
\text { Contran } n^{\circ} 171 / 2005 \text {. Altera a Resolução Contran } n^{\circ} 165 / 2004 \text {. Em vigor. }\end{array}$ \\
\hline $202 / 2006$ & $\begin{array}{l}\text { Regulamenta a Lei } n^{\circ} 11.334 \text {, de } 25 \text { de julho de 2006, que alterou o Art. } 218 \\
\text { da Lei } n^{\circ} \text { 9.503/97, que instituiu o CTB. Revogada em parte pela Resolução } \\
\text { Contran } n^{\circ} 396 / 2011 \text {. Referenda a Deliberação Contran } n^{\circ} \text { 51/2006. }\end{array}$ \\
\hline $214 / 2006$ & $\begin{array}{l}\text { Altera o Art. } 3^{\circ} \text { e o Anexo I, acrescenta o Art. } 5^{\circ} \text { A e o Anexo IV da } \\
\text { Resolução Contran } n^{\circ} 146 / 2003 \text { e dá outras providências. Em vigor a partir } \\
\text { de } 22 \text { de novembro de } 2006 \text {. Acresce o Anexo IV, altera o Anexo I e revoga } \\
\text { o } \S 4^{\circ} \text { do Art. } 5^{\circ} \text { da Resolução Contran } n^{\circ} 146 / 2003 \text {. Revogada pela } \\
\text { Resolução Contran } n^{\circ} 396 / 2011 \text {. }\end{array}$ \\
\hline $340 / 2010$ & $\begin{array}{l}\text { Referenda a Deliberação Contran } n^{\circ} 86 / 2009 \text {, que altera a Resolução } \\
\text { Contran n } n^{\circ} 146 / 2003 \text {, estabelecendo critérios para informação complementar } \\
\text { à placa R-19. Altera a Resolução Contran } n^{\circ} \text { 146/2003. Revogada pela } \\
\text { Resolução Contran } n^{\circ} 396 / 2011 \text {. }\end{array}$ \\
\hline $396 / 2011$ & $\begin{array}{l}\text { Dispõe sobre requisitos técnicos mínimos para a fiscalização da velocidade } \\
\text { de veículos automotores, reboques e semirreboques, conforme o CTB. } \\
\text { Revoga as Resoluções Contran } n^{\circ} 146 / 2003,214 / 2006,340 / 2010 \text { e o Art. } 3^{\circ} \\
\text { e o Anexo II da Resolução Contran n } n^{\circ} 202 / 2006 \text {. Em vigor. }\end{array}$ \\
\hline $404 / 2012$ & $\begin{array}{l}\text { Dispõe sobre a padronização dos procedimentos administrativos na lavratura } \\
\text { de auto de infração, na expedição de notificação de autuação e de notificação } \\
\text { de penalidade de multa e de advertência, por infração de responsabilidade de } \\
\text { proprietário e de condutor de veículo e da identificação de condutor infrator, } \\
\text { e dá outras providências. Revoga a Resolução Contran n } n^{\circ} 363 / 2010 \text { (não } \\
\text { vigorou). Alterada pela Resolução Contran n } n^{\circ} 424 / 2012 \text {. Em vigor }\end{array}$ \\
\hline $424 / 2012$ & $\begin{array}{l}\text { Altera o prazo previsto no Art. } 27 \text { da Resolução Contran no 404/2012, que } \\
\text { dispõe sobre a padronização dos procedimentos administrativos na lavratura } \\
\text { de auto de infração, na expedição de notificação de autuação e de notificação } \\
\text { de penalidade de multa e de advertência, por infração de responsabilidade de } \\
\text { proprietário e de condutor de veículo e da identificação de condutor infrator, } \\
\text { e dá outras providências. Altera a Resolução Contran n }{ }^{\circ} 404 / 2012 \text {. }\end{array}$ \\
\hline $458 / 2013$ & $\begin{array}{l}\text { Altera a Resolução Contran } \mathrm{n}^{\circ} 165 \text {, de } 10 \text { de setembro de } 2004 \text {, que } \\
\text { regulamenta a utilização de sistemas automáticos não metrológicos de } \\
\text { fiscalização, nos termos do } \S 2^{\circ} \text { do Art. } 280 \text { do CTB. Em vigor. }\end{array}$ \\
\hline $471 / 2013$ & $\begin{array}{l}\text { Regulamenta a fiscalização de trânsito por intermédio de } \\
\text { videomonitoramento em estradas e rodovias, nos termos do } \S 2^{\circ} \text { do Art. } 280 \\
\text { do CTB. Em vigor. }\end{array}$ \\
\hline
\end{tabular}

Fonte: Adaptado de <www.denatran.gov.br/resolucoes.htm>. 
A primeira resolução a tratar da fiscalização eletrônica, em atendimento ao $\S 2^{\circ}$ do Art. 280 do CTB (BRASIL, 1997), foi a Resolução Contran nº 23, de 21 de maio de 1998 (CONTRAN, 1998a), que definiu e estabeleceu os requisitos mínimos necessários para a autorização e instalação de instrumentos eletrônicos de medição de velocidade de operação autônoma. Como requisitos básicos necessários para a instalação dos equipamentos estavam a aprovação, certificação e verificação anual pelo Instituto Nacional de Metrologia, Qualidade e Tecnologia (Inmetro), bem como o registro de informações do equipamento e dos dados da infração. Observa-se que somente os instrumentos eletrônicos de medição de velocidade estavam regulamentados e não havia necessidade de estudos técnicos para a sua instalação.

Em 19 de novembro de 1998, a Resolução Contran $n^{\circ} 79$ (CONTRAN, 1998b), que estabeleceu a sinalização indicativa, dispôs que toda fiscalização eletrônica que tivesse como fato gerador o controle da velocidade deveria ser indicada por sinalização vertical, estabelecendo a velocidade máxima permitida. A sinalização educativa indicando "fiscalização eletrônica" passou a ser facultativa após essa resolução.

Com relação ao ASV, não se aplicava a necessidade de sinalização indicativa e os equipamentos em uso deveriam ser aferidos pelo Inmetro no prazo de 180 dias. Esse prazo foi prorrogado posteriormente pelas Resoluções Contran $n^{\circ}$ 111/2000 (CONTRAN, 2000a), $n^{\circ}$ 118/2000 (CONTRAN, 2000b) e n⿳ 125/2001 (CONTRAN, 2001).

A Resolução Contran no 131, de 2 de abril de 2002 (CONTRAN, 2002a), dispôs sobre requisitos técnicos mínimos para a fiscalização da velocidade de veículos automotores, elétricos, reboques e semirreboques, conforme o CTB (BRASIL, 1997). Contudo, foi revogada pela Deliberação Contran $n^{\circ} 34$, de 9 de maio de 2002, e declarada nula pela Resolução Contran n 140, de 19 de setembro de 2002 (CONTRAN, 2002c).

Em 3 de outubro de 2002 a Resolução Contran nº 141 (CONTRAN, 2002d) dispôs sobre o uso, a localização, a instalação e a operação de aparelho, de equipamento ou de qualquer outro meio tecnológico para auxiliar na gestão do trânsito, revogando, dentre outras, as Resoluções Contran no 23/1998 (CONTRAN, 1998a) e nº 79/1998 (CONTRAN, 1998b).

A Resolução Contran n ${ }^{\circ}$ 141/2002 (CONTRAN, 2002d) trouxe pela primeira vez, em seu Art. $2^{\circ}, \S 1^{\circ}$, a necessidade de se realizar estudos técnicos para a fiscalização eletrônica das 
infrações previstas nos artigos 183 (parar o veículo sobre a faixa de pedestres na mudança de sinal luminoso), 208 (avançar o sinal vermelho do semáforo ou o de parada obrigatória) e 218 (transitar em velocidade superior à máxima permitida para o local) do CTB (BRASIL, 1997). A placa educativa indicando fiscalização eletrônica, antes facultativa, passou a ser obrigatória $\left(\right.$ Art. $\left.7^{\circ}\right)$.

Art. $2^{\circ}$. Compete à autoridade de trânsito com circunscrição sobre a via dispor sobre a localização, a instalação e a operação de aparelho, de equipamento ou de qualquer outro meio tecnológico disponível referido nesta Resolução.

$\S 1^{\circ}$ A definição do local de instalação de aparelho, de equipamento ou de qualquer outro meio tecnológico, para fins do $\S 2^{\circ}$ do Art. 280 do CTB, deverá ser precedida de estudos técnicos que contemplem, dentre outras variáveis, os índices de acidentes, as características da localidade, a velocidade máxima da via, a geometria da via, a densidade veicular, o potencial de risco aos usuários, e que comprovem a necessidade de fiscalização, sempre dando prioridade à educação para o trânsito e à redução e prevenção de acidentes. (CONTRAN, 2002d)

De acordo com Vieira (2003), a Resolução Contran nº 141/2002 (CONTRAN, 2002d) foi uma tentativa de corrigir supostas práticas abusivas do sistema de fiscalização eletrônica, em que a necessidade de estudo vincularia a fiscalização aos objetivos de redução de acidentes, não a objetivos arrecadatórios. Destaca o autor que, na época, as empresas prestadoras dos serviços de fiscalização eletrônica eram remuneradas conforme a quantidade de multas aplicadas.

A respeito desse tema, Yang, Han e Cherry (2013) relacionam as implicações políticas e financeiras dos programas de fiscalização eletrônica, apresentando medidas de engenharia que afetam a segurança e eficiência nos cruzamentos. O artigo discute os desafios éticos e os impactos negativos dessas medidas sobre a segurança do cruzamento, bem como a eficiência, credibilidade e imagem pública dos órgãos relacionados e dos políticos eleitos.

A Resolução Contran no 146, de 27 de agosto de 2003 (CONTRAN, 2003), que dispôs sobre requisitos técnicos mínimos para a fiscalização da velocidade de veículos automotores, reboques e semirreboques, conforme o CTB, revogou a Resolução Contran no 141/2002 (CONTRAN, 2002d) e foi alterada pelas Resoluções Contran n ${ }^{\circ}$ 165/2004 (CONTRAN, 2004a), que revogou o Art. 6 $; n^{\text {o }}$ 202/2006 (CONTRAN, 2006a), que alterou a tabela de valores referenciais do Anexo II; nº 214/2006 (CONTRAN, 2006b). 
Como destaque da Resolução Contran no 146/2003 (CONTRAN, 2003), tem-se que os estudos técnicos deixaram de ser obrigatórios para instrumentos de fiscalização de ASV e PSF, ficando restritos aos medidores de velocidade. Dentre os considerandos que justificam essa mudança, transcreve-se:

Considerando a necessidade de não haver interrupção da fiscalização por instrumento ou equipamento hábil de avanço de sinal vermelho e de parada de veículo sobre a faixa de pedestres na mudança de sinal luminoso de veículos automotores, reboques e semi-reboques, sob pena de um aumento significativo da ocorrência de elevação dos atuais números de mortos e feridos em acidentes de trânsito. (CONTRAN, 2003)

A Resolução Contran no 214, de 13 de novembro de 2006 (CONTRAN, 2006b), alterou o Anexo I da Resolução Contran nº 146/2003 (CONTRAN, 2003), introduzindo os modelos de estudos técnicos para instalação de medidores de velocidade (modelo A) e para monitoramento da eficácia dos instrumentos medidores de velocidade (modelo B).

Com foco específico na regulamentação da instalação de EFEs, têm-se vigentes as seguintes resoluções por tipo de equipamento:

\subsubsection{Medidores de velocidade}

- Resolução Contran n ${ }^{\circ}$ 396, de 13 de dezembro de 2011 (CONTRAN, 2011) - Dispõe sobre requisitos técnicos mínimos para a fiscalização da velocidade de veículos automotores, reboques e semirreboques, conforme o CTB. Revoga as Resoluções Contran nº 146/2003,

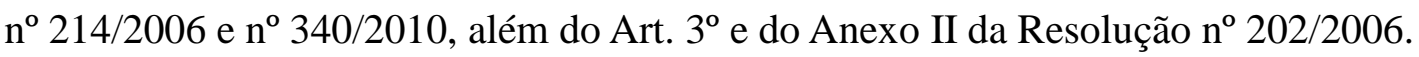

Constam do Anexo I, item A, as variáveis do modelo de estudo para determinar a necessidade da instalação de medidor de velocidade do tipo fixo, que venham a comprovar a necessidade de controle ou redução do limite de velocidade no local, garantindo a visibilidade do equipamento.

Constam do Anexo I, item B, as variáveis do modelo de estudo para medir a eficácia dos medidores de velocidade do tipo fixo, com periodicidade máxima de doze meses.

A Resolução no 396/2011 estabelece as seguintes definições em seu Art. $1^{\text {o }}$, § $1^{\text {o }}$ : 
a) medidor de velocidade: instrumento ou equipamento destinado à medição de velocidade de veículos.

b) controlador eletrônico de velocidade: medidor de velocidade destinado a fiscalizar o limite máximo regulamentado para a via ou trecho por meio de sinalização (placa R-19) ou, na sua ausência, pelos limites definidos no art. 61 do CTB;

c) redutor eletrônico de velocidade (barreira ou lombada eletrônica): medidor de velocidade, do tipo fixo, com dispositivo registrador de imagem, destinado a fiscalizar a redução pontual de velocidade em trechos considerados críticos, cujo limite é diferenciado do limite máximo regulamentado para a via ou trecho em um ponto específico indicado por meio de sinalização (placa R-19). (CONTRAN, 2011, grifo nosso)

Com relação aos estudos técnicos, a Resolução Contran n 396/2011 assim estabelece em seu Art. $4^{\circ}, \S 2^{\circ}$ e $\S 3^{\circ}$ :

Art. $4^{\circ}$ Cabe à autoridade de trânsito com circunscrição sobre a via determinar a localização, a sinalização, a instalação e a operação dos medidores de velocidade do tipo fixo.

$[\ldots]$

$\S 2^{\circ}$ Para determinar a necessidade da instalação de medidor de velocidade do tipo fixo, deve ser realizado estudo técnico que contemple, no mínimo, as variáveis do modelo constante no item A do Anexo I, que venham a comprovar a necessidade de controle ou redução do limite de velocidade no local, garantindo a visibilidade do equipamento.

$\S 3^{\circ}$ Para medir a eficácia dos medidores de velocidade do tipo fixo ou sempre que ocorrerem alterações nas variáveis constantes no estudo técnico, deve ser realizado novo estudo técnico que contemple, no mínimo, o modelo constante no item B do Anexo I, com periodicidade máxima de 12 (doze) meses. (CONTRAN, 2011, grifo nosso)

Por oportuno, em comparação ao considerando da Resolução Contran $n^{\circ}$ 146/2003 (CONTRAN, 2003), que justificou a ausência de estudo para o equipamento automático não metrológico que fiscaliza o ASV, em razão de não haver interrupção na fiscalização sob pena de um aumento significativo dos atuais números de mortos e feridos em acidentes de trânsito, a Resolução Contran n 396/2011 (CONTRAN, 2011), que estabelece a obrigatoriedade de estudo para medidores de velocidade, traz como considerando "a importância da fiscalização de velocidade como instrumento para redução de acidentes e de sua gravidade".

Embora ambos os equipamentos tenham como objetivo o cumprimento da sinalização por parte do condutor, visando à redução da quantidade e da gravidade dos acidentes, entende-se contraditória a obrigatoriedade de estudo somente para medidores de velocidade. 
O sentido de se realizar estudo técnico para medidores de velocidade não pode ser distorcido de modo a colocar em dúvida a fiscalização de condutas inadequadas. Além disso, o comprometimento dos órgãos de trânsito em adotar um conjunto de ações de segurança viária não deve se limitar à instalação de EFEs.

Ainda que se interprete na legislação vigente que a fiscalização eletrônica de ASV sempre se justifica em razão de que as ocorrências dessa infração têm impacto muito grande na segurança viária da interseção, assume-se neste trabalho que o balizamento para a aplicação dos recursos disponíveis em locais de maior necessidade (críticos), a avaliação das condições da via (geométricas, de infraestrutura e de sinalização) e a verificação da eficácia de equipamentos, de fiscalização ou não, deveriam fazer parte das ações dos órgãos de trânsito em qualquer situação, assim como o Art. $1^{\circ}$, $\S 3^{\circ}$, da Lei no 9.503/1998 (BRASIL, 1997) deveria ter sua frequência mais bem aplicada.

$\S 3^{\circ}$ Os órgãos e entidades componentes do Sistema Nacional de Trânsito respondem, no âmbito das respectivas competências, objetivamente, por danos causados aos cidadãos em virtude de ação, omissão ou erro na execução e manutenção de programas, projetos e serviços que garantam o exercício do direito do trânsito seguro. (BRASIL, 1997)

\subsubsection{Sistemas automáticos não metrológicos de fiscalização}

- Resolução Contran no 165, de 10 de setembro de 2004 (CONTRAN, 2004a). Regulamenta a utilização de sistemas automáticos não metrológicos de fiscalização, nos termos do $\S 2^{\circ}$ do Art. 280 do CTB.

Essa resolução não vincula a necessidade de estudo com a utilização de sistemas automáticos não metrológicos, como constava da Resolução Contran n 141/2002 (CONTRAN, 2002d), revogada pela Resolução Contran nº 146/2003 (CONTRAN, 2003). Também dispõe que não é obrigatória a utilização de sinalização vertical de indicação educativa prevista no Anexo II do CTB (Art. $5^{\circ}$, inciso I).

- Resolução Contran no 174, de 23 de junho de 2005 (CONTRAN, 2005). Altera e esclarece dispositivos da Resolução Contran n ${ }^{\circ}$ 165/2004, que trata da regulamentação da utilização 
de sistemas automáticos não metrológicos de fiscalização, nos termos do $\S 2^{\circ}$ do Art. 280 do CTB.

Essa resolução dispõe sobre alterações relativas à conformidade do equipamento a ser realizada pelo Inmetro.

- Resolução Contran n 458, de 29 de outubro de 2013 (CONTRAN, 2013a). Altera a Resolução Contran n 165/2004, que regulamenta a utilização de sistemas automáticos não metrológicos de fiscalização, nos termos do $\S 2^{\circ}$ do Art. 280 do CTB.

Ainda que a Resolução Contran $n^{\circ}$ 146/2003 (CONTRAN, 2003) tenha retirado a obrigatoriedade de estudo técnico para ASV e PSF na mudança de sinal luminoso, como se verá adiante, a Portaria Denatran n ${ }^{\circ}$ 16/2004 (DENATRAN, 2004), estabeleceu requisitos específicos mínimos dos sistemas automáticos não metrológicos para a físcalização das infrações previstas no CTB.

A Resolução Contran nº 458/2013 dispôs em seu Art. $3^{\circ}$ :

Art. $3^{\circ}$ Acrescentar o art. $9^{\circ}$-A à Resolução CONTRAN no 165 , de 10 de setembro de 2004, com a seguinte redação:

"Art.9"-A. O órgão máximo executivo de trânsito da União disporá sobre os requisitos técnicos para instalação e fiscalização por meio do sistema automático não metrológico de fiscalização." (CONTRAN, 2013a, grifo nosso)

Dessa forma, conforme dispõe a Resolução Contran nº 458/2013, ainda não há legislação que regulamente os requisitos técnicos para instalação e fiscalização por meio de sistema automático não metrológico de fiscalização.

Cabe observar que em nenhuma legislação citada (de equipamentos metrológicos e não metrológicos) há menção explícita à redução de infrações como fator de avaliação da eficácia dos EFEs. 


\subsubsection{Videomonitoramento}

- Resolução Contran n 471, de 18 de dezembro de 2013 (CONTRAN, 2013b). Regulamenta a fiscalização de trânsito por intermédio de videomonitoramento em estradas e rodovias, nos termos do $\S 2^{\circ}$ do Art. 280 do CTB.

\subsection{DEPARTAMENTO NACIONAL DE TRÂNSITO (DENATRAN)}

O órgão máximo executivo de trânsito da União tem legislado por meio de portarias. $\mathrm{O}$ histórico de portarias sobre a utilização de meio eletrônico para fiscalização do trânsito pode ser visualizado no Quadro 2.2.

Quadro 2.2: Histórico das portarias do Denatran relacionadas aos EFEs e aos objetivos do trabalho

\begin{tabular}{|c|c|}
\hline $\begin{array}{l}\text { Portaria } \\
\text { Denatran }\end{array}$ & Assunto e Situação \\
\hline $02 / 2002$ & $\begin{array}{l}\text { Estabelece a tabela de valores referenciais de velocidade, Anexo I, para } \\
\text { fins de autuação/penalidade por infração ao Art. } 218 \text { do CTB. }\end{array}$ \\
\hline $16 / 2004$ & $\begin{array}{l}\text { Estabelece os requisitos específicos mínimos dos sistemas automáticos não } \\
\text { metrológicos para a fiscalização das infrações previstas no CTB. }\end{array}$ \\
\hline $27 / 2005$ & $\begin{array}{l}\text { Amplia as infrações que podem ser fiscalizadas com a utilização de } \\
\text { sistemas automáticos não metrológicos e estabelece os requisitos } \\
\text { específicos mínimos. }\end{array}$ \\
\hline $263 / 2007$ & $\begin{array}{l}\text { Estabelece os requisitos específicos mínimos do sistema automático não } \\
\text { metrológico para a fiscalização das seguintes infrações de trânsito previstas } \\
\text { no CTB: I - Executar operação de retorno em locais proibidos pela } \\
\text { sinalização (Art. 206, inciso I); II - Executar operação de conversão à } \\
\text { direita ou à esquerda em locais proibidos pela sinalização (Art. 207). }\end{array}$ \\
\hline $870 / 2010$ & $\begin{array}{l}\text { Estabelece os requisitos específicos mínimos do sistema automático não } \\
\text { metrológico para a fiscalização das infrações previstas no Art. } 209 \text { do CTB } \\
\text { para as seguintes condutas: I - deixar de adentrar as áreas destinadas à } \\
\text { pesagem de veículos; II - transpor, sem autorização, bloqueio viário } \\
\text { localizado na saída das áreas destinadas à pesagem de veículos. }\end{array}$ \\
\hline $407 / 2011$ & $\begin{array}{l}\text { Aprova a Cartilha de Aplicação de Recursos Arrecadados com a Cobrança } \\
\text { de Multas de Trânsito nos termos do Anexo. }\end{array}$ \\
\hline $494 / 2011$ & $\begin{array}{l}\text { Altera o caput do Art. } 10 \text { da Cartilha de Aplicação de Recursos } \\
\text { Arrecadados com a Cobrança de Multas de Trânsito. }\end{array}$ \\
\hline $1.113 / 2011$ & $\begin{array}{l}\text { Altera as portarias Denatran } \mathrm{n}^{\circ} 16 / 2004, \mathrm{n}^{\circ} 263 / 2007 \text { e } \mathrm{n}^{\circ} 870 / 2010 \text {, que } \\
\text { estabelecem requisitos mínimos para a fiscalização de diferentes infrações } \\
\text { por meio de sistema automático não metrológico de fiscalização de } \\
\text { trânsito. }\end{array}$ \\
\hline $85 / 2014$ & $\begin{array}{l}\text { Altera a Portaria Denatran } \mathrm{n}^{\circ} 16 / 2004 \text {, para dispensar a elaboração de } \\
\text { projeto-tipo para cada local fiscalizado com sistema automático não } \\
\text { metrológico móvel. }\end{array}$ \\
\hline
\end{tabular}

Fonte: Adaptado de <www.denatran.gov.br/portarias.htm> 
A Portaria Denatran no 16/2004 (DENATRAN, 2004), que estabelece requisitos específicos mínimos dos sistemas automáticos não metrológicos para a fiscalização das infrações previstas no CTB, foi alterada pelas portarias $n^{\circ} 1.113 / 2011$ (DENATRAN, 2011) e $n^{\circ}$ 85/2014 (DENATRAN, 2014). Foram acrescidos também os tipos de infrações fiscalizadas por sistema não metrológico pelas portarias $n^{\circ}$ 27/2005 (DENATRAN, 2005), $n^{\circ}$ 263/2007 (DENATRAN, 2007) e no 870/2010 (DENATRAN, 2010a).

Conforme a Portaria Denatran $n^{\circ}$ 16/2004, para sistemas não metrológicos de fiscalização devem ser observados os seguintes aspectos:

Art. $3^{\circ}$ A autoridade de trânsito com circunscrição sobre a via, antes de utilizar o sistema automático não metrológico de fiscalização, deve elaborar projeto tipo para cada local fiscalizado.

$[\ldots]$

Art. $4^{\circ}$ Para as infrações previstas nos incisos I e II do art. $1^{\circ}$ desta portaria, a autoridade de trânsito com circunscrição sobre a via, antes de utilizar o sistema automático não metrológico de fiscalização, deve elaborar para cada local fiscalizado, justificativa do valor determinado para o tempo de:

I - retardo, quando registrar infração por Avançar o Sinal Vermelho do Semáforo;

II - permanência, quando registrar infração por Parar o Veículo sobre a Faixa de Pedestre na mudança de sinal luminoso.

$[\ldots]$

Art. $6^{\circ}$. O sistema automático não metrológico de fiscalização de avanço de sinal vermelho deve:

I - registrar a imagem após o veículo transpor a área de influência do(s) sensor(es) destinado(s) a caracterizar o avanço do sinal vermelho do semáforo fiscalizado, estando o foco vermelho ativado e respeitado o tempo de retardo determinado para o local pela autoridade de trânsito com circunscrição sobre a via;

II - permanecer inibido, não registrando imagem enquanto estiver ativo o foco verde ou o foco amarelo do semáforo fiscalizado;

III - possibilitar a configuração de tempo de retardo de, no mínimo, 0 (zero) e, no máximo, 5 (cinco) segundos; em passos de um segundo;

IV - na imagem detectada registrar, além do estabelecido no art. $4^{\circ}$ da Resolução CONTRAN no 165 , no mínimo:

a) o foco vermelho do semáforo fiscalizado;

b) a faixa de travessia de pedestres, mesmo que parcial, ou na sua inexistência, a linha de retenção da aproximação fiscalizada. (DENATRAN, 2004)

$[\ldots]$

Projeto tipo: é a caracterização da aproximação, da faixa ou da pista a ser fiscalizada, através de desenho esquemático contendo as dimensões e distâncias entre, no mínimo, os seguintes elementos:

I. para infrações de Avanço de Sinal Vermelho do Semáforo e Parada sobre a Faixa de Travessia de Pedestres na Mudança de Sinal Luminoso:

a) linha de retenção;

b) faixa de travessia de pedestres (quando existir); 
c) sensor(es) destinados a detectar o veículo infrator;

d) semáforo fiscalizado. (DENATRAN, 2004)

[...]

Tempo de Retardo: é o período de tempo, após o início do sinal vermelho fiscalizado, em que o sistema automático não metrológico de fiscalização de avanço de sinal vermelho do semáforo permanece inibido ao registro da imagem do veículo. Este período, determinado pela autoridade de trânsito com circunscrição sobre a via, deve considerar as situações específicas de cada local fiscalizado, de forma que seja assegurado o registro da imagem, somente, dos veículos que tenham recebido a indicação luminosa vermelha antes da faixa de retenção da aproximação fiscalizada.

Destaca-se como análise o intervalo mínimo de configuração do tempo de retardo de $0 \mathrm{~s}$, em razão do que estabelece o Art. $6^{\circ}$ da Portaria Denatran $n^{\circ} 16 / 2004$, em que o registro da infração de ASV deve ser feito após o veículo transpor a área de influência dos sensores destinados a caracterizar a infração, estando o foco vermelho ativado e respeitado o tempo de retardo determinado para o local frente à definição de tempo de retardo disposta no Anexo I da supracitada portaria, onde deve ser assegurado o registro da imagem somente dos veículos que tenham recebido a indicação luminosa vermelha antes da faixa de retenção. Para que o tempo de retardo seja de $0 \mathrm{~s}$ os laços indutivos deveriam estar posicionados antes da linha retenção em distância superior ao comprimento do veículo. Isto implicaria que todos os veículos que chegassem à aproximação durante a indicação vermelha do semáforo e parassem no limite da linha de retenção passariam pelos laços indutivos e seriam registrados pelos equipamentos. A simples auditoria em momento posterior para cancelar essas infrações incorretas não daria cumprimento ao que estabelece a portaria.

Os estudos estabelecidos pela Portaria Denatran $n^{\circ}$ 16/2004 foram observados nas visitas in loco e fazem parte dos resultados apresentados. 


\section{REFERENCIAL TEÓRICO}

O presente capítulo aborda a caracterização da infração ASV, a instalação de EFEs, os fatores que influenciam a redução de infrações, as contramedidas de engenharia associadas e o cálculo do tempo de retardo.

\subsection{CARACTERIZAÇÃO DO AVANÇO DE SINAL}

O ASV, descrito no Art. 208 do CTB (BRASIL, 1997), é infração gravíssima com penalidade de multa. Quando da utilização de sistema automático não metrológico de fiscalização, nos termos do Anexo I da Portaria Denatran $n^{\circ}$ 16/2004 (DENATRAN, 2004), deve ser assegurado o registro da imagem somente dos veículos que tenham recebido a indicação luminosa vermelha antes da faixa de retenção da aproximação fiscalizada.

Assim, caracteriza a infração de ASV a passagem do veículo pela linha de retenção durante a indicação de luz vermelha, referida como regra do "amarelo permissivo", em comparação com leis mais restritivas que exigem que os condutores tenham saído do cruzamento antes do final do intervalo de amarelo.

De acordo com Bonneson, Zimmerman e Brewer (2002), pela regra do "amarelo permissivo", um condutor que recebe a indicação verde do semáforo deve esperar até que todos os outros veículos que entraram legalmente na interseção tenham deixado o cruzamento, antes de prosseguir. Quem adentra na interseção ainda no amarelo não comete infração.

Parsonson et al. (1993 apud BONNESON, ZIMMERMAN e BREWER, 2002) indicam que pelo menos metade dos estados norte-americanos seguem a regra permissiva. A vantagem é que ela permite que a maioria dos condutores esteja dentro da lei em suas respostas à indicação de amarelo. A desvantagem é que ela cria uma situação em que o condutor que recebe a indicação verde, antes de entrar no cruzamento, deve ceder a preferência para quem já está no cruzamento. O uso do vermelho geral, calculado com duração igual ao tempo de travessia mais o tempo da passagem do veículo, elimina esse problema.

Vanlaar, Robertson e Marcoux (2014) afirmam que a cidade de Winnipeg também se utiliza da regra do amarelo permissivo. Parsonson et al. (1993 apud BONNESON, ZIMMERMAN e 
BREWER, 2002) indicam que $60 \%$ dos condutores não sabem que eles têm de ceder o direito de passagem quando da indicação do sinal verde.

Segundo Pauw et al. (2014a), em Flandres, na Bélgica, as câmeras de ASV detectam veículos por meio de dois laços indutivos espaçados, embutidos no pavimento. O sistema compara a informação sobre a velocidade do veículo na linha de retenção com a fase do semáforo, a fim de analisar ASV. Quando um veículo se move na indicação de luz vermelha, duas fotografias são tiradas: uma quando o veículo atravessa a linha de retenção e a outra para determinar se o veículo continua ou não através do cruzamento. Além disso, câmeras de ASV medem a velocidade de condução através do cálculo do tempo que o veículo precisa para passar os dois laços indutivos.

Conforme o volume V do Manual Brasileiro de Sinalização de Trânsito, intitulado Sinalização semafórica (CONTRAN, 2014), anexo da Resolução Contran $\mathrm{n}^{\circ}$ 483/2014, detectores de tráfego são dispositivos que têm a função de captar a demanda de tráfego - veículos motorizados, não motorizados e pedestres - em determinado local. Dentre as diferentes tecnologias utilizadas para esse tipo de dispositivo, que são escolhidas de acordo com a necessidade funcional e com as características de cada local, o Distrito Federal adota laços detectores indutivos. Esses dispositivos são constituídos por cabos metálicos inseridos no pavimento, conectados a circuitos eletrônicos dos controladores.

Nesses cabos circula corrente elétrica que forma um campo magnético, o qual sofre alterações quando da passagem ou presença de massa metálica. Tais alterações indicam aos controladores a passagem ou presença dos veículos.

Em Winnipeg, de acordo com Vanlaar, Robertson e Marcoux (2014), quando um veículo é detectado passando sobre os sensores ativados, são tiradas duas fotografias. A primeira é do veículo fora da interseção (na linha de retenção) e mostra que o sinal está vermelho. A segunda exibe o mesmo veículo no cruzamento com a indicação de luz ainda vermelha. Qualquer veículo que esteja esperando para fazer a conversão à esquerda ou esteja parado no cruzamento em razão do acúmulo de tráfego não é fotografado. As imagens são revistas manualmente pela equipe de fiscalização em processo de validação para evitar a emissão de infrações de falsos-positivos. 
Vanlaar, Robertson e Marcoux (2014) explicam que, para detectar excesso de velocidade nos cruzamentos, esses mesmos sensores detectam a presença de veículos e calculam velocidade usando tempo e distância. Se a velocidade do veículo ultrapassar o limite de velocidade predeterminado, a câmera será acionada para fotografar o veículo que atravessa o cruzamento.

Nos Estados Unidos, veículos podem realizar a conversão à direita mesmo com a indicação vermelha do semáforo, desde que façam uma parada total e deem a preferência a pedestres e veículos em conflito. McCartt e Hu (2014) apontam que a tecnologia de fiscalização por câmera é incapaz de determinar se os veículos fizeram uma parada total antes de fazer a conversão à direita no vermelho, como exigido pela lei. Nesses casos, as infrações são emitidas para condutores que realizam a conversão à direita na indicação vermelha do semáforo ao trafegar a mais de dez quilômetros por hora, sujeita a revisão por policiais.

De acordo com McCartt e Hu (2014), deve haver um período mínimo de carência de 0,5 s após o sinal ficar vermelho. Condutores não podem ser fotografados, imagens de veículos devem ser tomadas antes e depois do veículo entrar no cruzamento e um policial deve validar todas as infrações com base em inspeção de fotografias ou vídeo.

No Detran/DF, $10 \%$ do total de infrações encaminhadas pela empresa prestadora desse serviço são auditadas. Os veículos são autuados por ASV na entrada e na saída da zona de detecção, com tempo de retardo de $1 \mathrm{~s}$ após a indicação do sinal vermelho, adotado indistintamente para todas as interseções. Destaca-se que, em congestionamentos, caso o condutor esteja parado sobre o laço indutivo, assim bloqueando o cruzamento ou a faixa de travessia de pedestres, tem-se o tempo de $10 \mathrm{~s}$ para retroceder o veículo e posicioná-lo antes da linha de retenção. Caso continue parado, o condutor será autuado por bloquear o cruzamento; caso prossiga, mesmo já tendo cruzado a linha de retenção na indicação verde do semáforo, será autuado por ASV. Não há legislação determinando o percentual mínimo de infrações a serem auditadas pelo órgão de trânsito antes do envio da notificação ao proprietário do veículo.

Como citado anteriormente, a Portaria Denatran no 16/2004 (DENATRAN, 2004) estabelece estudo específico para cada local na determinação do tempo de retardo, podendo este variar de $0 \mathrm{~s}$ a $5 \mathrm{~s}$. 


\subsection{INSTALAÇÃO DE EQUIPAMENTOS DE FISCALIZAÇÃO ELETRÔNICA DE AVANÇO DE SINAL}

Para McCartt e Hu (2014), condutores são mais propensos a cumprir as leis de trânsito se perceberem uma alta probabilidade de serem multados. Equipamentos de fiscalização eletrônica de ASV podem complementar os métodos tradicionais de fiscalização nos cruzamentos, especialmente em momentos do dia e em vias onde a fiscalização tradicional pode ser difícil ou perigosa. Retting, Ferguson e Farmer (2007) entendem que câmeras de ASV aumentam a percepção do risco dos condutores que avançam sinal vermelho de serem pegos praticando a infração.

De acordo com a Teoria da Dissuasão de Gibbs (1979 apud CARNIS e BLAIS, 2013), programas de fiscalização eletrônica devem estar assentados em três princípios básicos: certeza de punição: alta probabilidade de ser detectado e condenado; rapidez na punição: em até oito dias; severidade da punição: valor da multa e pontos de demérito proporcionais à gravidade da infração.

Analisando cada um desses princípios, no Distrito Federal os EFEs fixos transmitem a sensação de certeza de punição, porém em locais restritos. A fiscalização pelo uso de equipamentos estáticos, móveis e portáteis é rara e condutores dificilmente são punidos por ASV fora dos locais fiscalizados por equipamentos fixos.

No Brasil, nos termos do caput do Art. $3^{\text {o }}$ da Resolução Contran n ${ }^{\circ}$ 404/2012 (CONTRAN, 2012), a autoridade de trânsito deve expedir a notificação da autuação dirigida ao proprietário do veículo, no prazo máximo de trinta dias contados da data do cometimento da infração. Superior, portanto, ao prazo de até oito dias recomendado por Gibbs (1979 apud CARNIS e BLAIS, 2013). Esse longo período significa, muitas vezes, que os condutores não se recordam da conduta inadequada que tiveram e do cometimento da infração.

Com relação à severidade da punição, o Art. 258 do CTB (BRASIL, 1997) estabelecia multa considerando como indexador de atualização dos valores a Unidade Fiscal de Referência (Ufir). Extinta a Ufir em outubro de 2000 pela Medida Provisória $n^{\circ} 1.973-67$, os valores passaram a ser estabelecidos pela Resolução Contran n 136, de 2002 (CONTRAN, 2002b), sem indexador, permanecendo fixos desde então e representando a cada ano valor real menor. 
Quanto à eficácia, um EFE de ASV é eficaz em determinado local quando reduz o índice de infrações e reduz a Unidade Padrão de Severidade (UPS) dos acidentes, ainda que haja aumento do índice de infrações.

No caso do Distrito Federal, não há dados disponíveis sobre o número de infrações antes da instalação dos EFEs para ASV ou da quantidade de acidentes por ASV categorizados por UPS (acidente com morte, acidente com ferido envolvendo pedestre, acidente com ferido e acidente sem ferido). Assim, os estudos para redução das infrações de ASV, inseridos no objetivo deste trabalho, baseiam-se em contramedidas de engenharia a serem consideradas nos locais onde estão localizados os EFEs, que fornecem o quantitativo de infrações por ASV.

Bonneson, Zimmerman e Brewer (2002) comparam fiscalização tradicional, que requer a presença da polícia, e fiscalização automatizada. Segundo os autores, a presença da polícia tem um efeito significativo a curto prazo, porém é caro para sustentar e quaisquer perseguições policiais que se seguirem podem representar um perigo para os espectadores. Por outro lado, uma desvantagem de sistemas automatizados é que eles não podem ser utilizados para identificar o condutor infrator, apenas o veículo. Os resultados da pesquisa relatada por Retting et al. (1998 apud BONNESON, ZIMMERMAN e BREWER, 2002) indicam que quase um terço dos condutores dos Estados Unidos são fortemente contra o uso de sistemas automatizados.

De acordo com Carnis e Blais (2013), dispositivos fixos de fiscalização eletrônica são geralmente instalados próximos a locais com alto índice de acidentes, ao passo que a localização de radares móveis utilizados em vários contextos depende do conhecimento e da estratégia de policiais.

Tay e Barros (2011 apud PULUGURTHA e OTTURU, 2014) citam que o programa de fiscalização eletrônica de ASV deve ser implementado em cruzamentos mais propensos a acidentes. A eficácia global e os benefícios dependem do fluxo de veículos totais e da história dos acidentes antes da implementação do programa de fiscalização eletrônica. A consideração do valor econômico dos acidentes e da análise de desempenho ajuda a quantificar melhor os benefícios monetários e a justificar a implementação do programa de fiscalização. 
McCartt e Hu (2014) recomendam que a seleção de cruzamentos com fiscalização eletrônica por câmeras deve considerar:

- As taxas de acidentes, o número de infrações, o tráfego de pedestres, bem como a dificuldade de realizar a fiscalização tradicional.

- A necessidade de realizar estudo de engenharia e de implementar melhorias de segurança viária específicas no local.

- A duração da fase de sinal amarelo, a ser baseada na metodologia recomendada pelo Institute of Traffic Engineers (ITE).

- Os sinais de alerta, que devem ser visivelmente colocados a uma distância de quinhentos pés do cruzamento (aproximadamente 152,4 m).

De acordo com Hallmark, Oneyear e McDonald (2012), a fiscalização eletrônica para ASV provoca um debate significativo e muitas vezes é interpretada como violação de privacidade. Em vista disso, os autores trazem as seguintes recomendações:

- Outras contramedidas menos invasivas devem ser consideradas em primeiro lugar. Recomenda-se que um estudo de engenharia seja realizado para selecioná-las. As agências devem documentar outras estratégias experimentadas antes da adoção das câmeras e compartilhar essa informação com o público.

- Tempo do semáforo, incluindo o intervalo de vermelho geral, deve ser verificado primeiro para garantir que está adequado.

- Embora exista uma correlação entre as infrações e os acidentes por ASV, nem todos os cruzamentos com um elevado número de violações também são locais de grandes acidentes. As câmeras são mais adequadas e mais facilmente defendidas quando usadas apenas em locais com uma história documentada de acidentes por ASV. Além disso, recomenda-se que uma agência selecione os locais mais apropriados para fiscalização com câmeras de ASV de acordo com um estudo de engenharia, em vez de trabalhar com um fornecedor de câmera para selecionar locais.

- Os gestores municipais devem ser transparentes e informar ao público a finalidade das câmeras antes de instalá-las. Ou seja, uma campanha de divulgação cuidadosamente planejada é recomendada antes de se adotar um programa de fiscalização automática. Meios de comunicação e mídias sociais podem educar o público nesse sentido. Recomenda-se período de aviso de um mês antes do início da implementação, emitindo-se 
advertências antes das infrações para que os condutores tenham tempo para se acostumar com as câmeras.

- Processo de revisão das infrações por policial antes de determinar se se deve ou não emitir uma infração.

- Sistemas de fiscalização com câmera de ASV geralmente oferecem a opção de gravar as violações, seja através de várias imagens estáticas ou de uma pequena captura de vídeo. $\mathrm{O}$ uso do vídeo permite "ver o contexto" de uma infração, facilitando a determinação de situações em que pode ser dado o benefício da dúvida ao condutor. Além disso, a opção de vídeo pode ser mais efetiva para o condutor, que pode se ver claramente avançando a luz vermelha.

- As agências devem ter uma política clara sobre a forma como vão determinar a emissão de uma infração. Em Iowa, nos Estados Unidos, na maioria das cidades as equipes têm trabalhado com a diretriz de que, se o agente de trânsito não multou um condutor no campo por uma violação de ASV, elas não irão emitir uma infração usando o sistema de câmera. Cenários onde a agência de trânsito não iria emitir uma infração devem ser claramente definidos. Essas situações muitas vezes estão associadas a cortejos fúnebres, condições climáticas adversas ou restrições de visão causadas pelo veículo à frente. Ter uma política que possa ser explicada aos infratores irá melhorar a percepção de justiça.

- Após a instalação, a localização das câmeras deve ser monitorada para garantir que estas sejam eficazes na redução de acidentes.

\subsubsection{Efeito colateral da utilização de equipamentos de fiscalização eletrônica para avanço de sinal vermelho}

Diversos estudos analisam os dados de acidentes e infrações relacionados à instalação de EFEs por meio de comparações de interseções fiscalizadas e não fiscalizadas. Avaliam assim o efeito colateral (spillover) que os EFEs podem causar, mesmo em cruzamentos não fiscalizados.

Segundo Vanlaar, Robertson e Marcoux (2014), embora alguns estudos tenham constatado que a fiscalização eletrônica trabalha para reduzir infrações de trânsito somente nos locais com câmera, outros sugerem que há uma influência nos cruzamentos sem câmera (CHEN et al., 2000; HESS, 2004; RETTING e KYRYCHENKO, 2002; RETTING et al., 1999; 
WASHINGTON, 2007 apud VANLAAR, ROBERTSON e MARCOUX, 2014). Tal influência sugere uma mudança mais generalizada no comportamento dos condutores.

Vanlaar, Robertson e Marcoux (2014) analisaram o impacto do programa de físcalização eletrônica na cidade de Winnipeg e constataram aumento de $25 \%$ em colisões traseiras nas interseções sem fiscalização. Os autores interpretaram que o aumento resulta do fato de que condutores assumem incorretamente que as câmeras estão presentes nesses cruzamentos e, como consequência, freiam bruscamente ao se aproximar de uma interseção com medo de serem multados.

McCartt e Hu (2014) verificaram o efeito da instalação de câmeras de ASV no número de infrações em oito cruzamentos semaforizados da Virgínia, Estados Unidos, sendo quatro cruzamentos com câmeras e quatro sem câmeras. O tráfego foi filmado em todas as interseções. As infrações de ASV nos cruzamentos fiscalizados diminuíram significativamente, e foram observados benefícios colaterais nas interseções sem fiscalização apenas para cruzamentos próximos aos corredores de viagem com câmeras.

Retting, Ferguson e Farmer (2007) analisaram o efeito do aumento do tempo de amarelo e da instalação de fiscalização eletrônica em seis interseções em New Jersey, Estados Unidos. Também foram monitoradas duas interseções sem fiscalização para comparação. O intervalo de amarelo nos locais experimentais foi aumentado em $1 \mathrm{~s}$ e nos locais de comparação permaneceu constante. Após alteração do intervalo de amarelo, índices de infração dos locais experimentais diminuíram, com reduções variando entre $21 \%$ e $63 \%$. Nos locais de comparação, no entanto, as mudanças não foram consistentes. Índices de infrações aumentaram $60 \%$ em um local de comparação, mas recuaram $27 \%$ em outro. Após o início da fiscalização por câmera, os índices de infrações nos locais experimentais diminuíram de 87\% a 100\% além daqueles observados após mudança do tempo de amarelo, enquanto as alterações nos locais de comparação foram novamente inconsistentes, aumentando $17 \%$ em um local mas diminuindo $4 \%$ em outro.

Lum e Wong (2003) estudaram o efeito antes e depois da instalação de três equipamentos de fiscalização por ASV em Singapura. Os autores encontraram maior propensão à parada do veículo, mas a eficácia ficou restrita a aproximações com câmera na interseção; não houve efeito significativo nas aproximações sem câmera nos mesmos cruzamentos. 


\subsubsection{Fiscalização eletrônica de avanço de sinal relacionada a acidentes de trânsito}

Estudos têm relacionado fiscalização eletrônica de ASV à redução do número de acidentes. Fitzsimmons et al. (2007 apud PULUGURTHA e OTTURU, 2014) constataram que o número médio de acidentes em interseções por trimestre diminuiu $20 \%$ em relação ao período anterior à fiscalização eletrônica, enquanto o número total de acidentes aumentou quase $7 \%$ em outros cruzamentos semaforizados.

Hu et al. (2011 apud PULUGURTHA e OTTURU, 2014) verificaram que os programas de fiscalização eletrônica para ASV foram associados a uma redução estatisticamente significativa de $24 \%$ na taxa de acidentes fatais por ASV e de $17 \%$ na taxa de todos os acidentes fatais em cruzamentos semaforizados, quando comparado com as taxas que seriam esperadas sem fiscalização eletrônica.

Garber et al. (2007 apud PULUGURTHA e OTTURU, 2014) concluíram que o número total de colisões traseiras aumentou após a implementação do programa de fiscalização eletrônica de ASV. Eles testaram a hipótese de que esse grande aumento no número de colisões traseiras pode diminuir quando o condutor estiver habituado ao local, mas não encontraram nenhuma mudança nesse sentido.

Hoye (2013 apud PAUW et al., 2014b) encontrou nos Estados Unidos uma diminuição não significativa de $12 \%$ no número de acidentes com feridos. Uma análise de acordo com o tipo de acidente mostrou um aumento de $19 \%$ no número de colisões traseiras e uma redução de $33 \%$ de acidentes em ângulo reto.

Cunningham e Hummer (2004 apud HALLMARK, ONEYEAR e McDONALD, 2012) realizaram um estudo na Carolina do Norte e constataram que câmeras de ASV reduziram acidentes totais, acidentes relacionados a ASV, acidentes em ângulo e colisões traseiras em $17 \%, 22 \%, 42 \%$ e $25 \%$, respectivamente.

Retting e Kyrychenko (2002 apud HALLMARK, ONEYEAR e McDONALD, 2012) descobriram que em Oxnard, Califórnia, o total de acidentes diminuiu 7\%, os acidentes em ângulo reto diminuíram $32 \%$ e houve pequeno aumento, mas não estatisticamente significativo (3\%), em colisões traseiras. 
Um estudo realizado por Malone et al. (2010 apud HALLMARK, ONEYEAR e McDONALD, 2012) analisou as taxas de acidentes em Calgary, no Canadá, durante cinco a sete anos após a instalação de câmeras de ASV. Houve diminuição de acidentes em ângulo reto $(48,2 \%)$ e de colisões traseiras $(8 \%)$.

Council et al. (2005 apud HALLMARK, ONEYEAR e McDONALD, 2012) observaram uma redução de 24,6\% em acidentes em ângulo reto e um aumento de 14,9\% em colisões traseiras em três estados norte-americanos.

Washington e Shin (2005 apud HALLMARK, ONEYEAR e McDONALD, 2012) obtiveram resultados semelhantes em Scottsdale, no estado norte-americano do Arizona, onde o total de acidentes, de acidentes em ângulo e de acidentes em conversão à esquerda diminuíram 11\%, $20 \%$ e $45 \%$, respectivamente, enquanto colisões traseiras aumentaram $41 \%$.

Pulugurtha e Otturu (2014) avaliaram e estimaram a eficácia do programa de fiscalização eletrônica de ASV na redução de acidentes "antes da instalação", "após a instalação" e "após o término do programa", na cidade de Charlotte, na Carolina do Norte. Os dados de 32 cruzamentos semaforizados eram relativos ao período de janeiro de 1997 a dezembro de 2010. Os equipamentos de fiscalização foram instalados entre agosto de 1998 e agosto de 2000, e o programa terminou em 2006. Os resultados obtidos indicaram aumento no número de colisões traseiras, porém uma redução de $50 \%$ no total de acidentes no período "antes da instalação após a instalação" e uma redução de 16\% no total de acidentes no período "antes da instalação - após o término do programa".

\subsubsection{Fiscalização eletrônica de avanço de sinal relacionada à redução de infrações}

A fiscalização eletrônica para ASV provou reduzir substancialmente, em cerca de $40 \%$ (RETTING et al., 1999a apud RETTING, FERGUSON e FARMER, 2007) a 78\% (MARTINEZ e PORTER, 2006 apud RETTING, FERGUSON e FARMER, 2007), as violações de luz vermelha em cidades dos Estados Unidos. Chen et al. (2001 apud RETTING, FERGUSON e FARMER, 2007) encontraram no Canadá uma redução de 69\% das violações de luz vermelha um mês após a introdução de fiscalização por câmeras, e um declínio de 38\% depois de seis meses. Uma revisão de estudos internacionais de ASV concluiu que as câmeras 
geralmente reduzem as violações de luz vermelha em cerca de $40 \%$ a 50\% (RETTING et al., 2003 apud RETTING, FERGUSON e FARMER, 2007).

Um estudo de Elvik et al. (2009 apud PAUW et al., 2014b) revelou uma redução entre $20 \%$ e $80 \%$ no número de infrações por ASV em razão do uso de fiscalização eletrônica. Reduções de infrações entre $18 \%$ e $90 \%$ em virtude de câmeras de ASV foram encontradas em Oxnard, Califórnia (RETTING et al., 1999a apud HALLMARK, ONEYEAR e McDONALD, 2012), Fairfax, Virgínia (RETTING et al., 1999b apud HALLMARK, ONEYEAR e McDONALD, 2012) e Chapel Hill e Raleigh, Carolina do Norte (CUNNINGHAM e HUMMER, 2004 apud HALLMARK, ONEYEAR e McDONALD, 2012).

Retting, Ferguson e Farmer (2007) entendem que a eficácia da fiscalização eletrônica de ASV pode estar relacionada com a forma como os programas são estruturados, embora nenhuma pesquisa até agora tenha questionado a importância de fatores específicos, tais como a publicidade sobre a fiscalização por câmera.

Acidentes por ASV geralmente caracterizam-se pela alta severidade, porém não ocorrem com frequência. McCartt e Hu (2014) destacaram a importância da análise do tempo em que o veículo comete a infração após a indicação da luz vermelha do semáforo. O estudo constatou que a fiscalização eletrônica apresentou maior redução de infrações quanto maior fosse o tempo em que o condutor avança o sinal, momento mais provável para o acidente ocorrer.

Bonneson, Zimmerman e Brewer (2002) destacam quatro situações em que medidas de fiscalização são válidas para reduzir o número de infrações: condutores não respeitam o sinal vermelho do semáforo; condutores julgam o avanço seguro em virtude do baixo volume de conflito; condutores julgam o avanço seguro pelo fato de a via transversal ser estreita; condutores julgam o avanço seguro por estarem a menos de $2 \mathrm{~s}$ atrás do veículo líder.

Para outras situações, esses autores recomendam contramedidas de engenharia envolvendo operação do semáforo, informação ao condutor e melhoria física, que serão tratadas posteriormente. 


\subsubsection{Fiscalização eletrônica conjunta de velocidade e avanço de sinal vermelho}

Alguns programas de fiscalização eletrônica têm sido utilizados para detectar "velocidade em verde", um tipo de fiscalização que captura veículos em velocidade através de cruzamentos com indicações de luzes verde e amarela. O programa da cidade de Winnipeg foi um dos primeiros na América do Norte a usar a tecnologia de velocidade em verde, mas há pouca informação sobre a eficácia desses dispositivos em excesso de velocidade nos cruzamentos (VANLAAR, ROBERTSON e MARCOUX, 2014).

Como citado anteriormente, as interseções urbanas semaforizadas que são fiscalizadas eletronicamente no Distrito Federal contam com equipamentos metrológicos (medição de velocidade) e não metrológicos (ASV e PSF).

Ainda que este estudo não avalie os efeitos dos equipamentos de medição de velocidade no índice de infrações de ASV, diversas pesquisas consideram essa influência. Para Blakey (2003 apud VANLAAR, ROBERTSON e MARCOUX, 2014), a fiscalização eletrônica mostrou provocar mudanças comportamentais significativas nos condutores, resultando em redução do desrespeito para com os sinais de trânsito e os limites de velocidade. De acordo com Evans (2006 apud VANLAAR, ROBERTSON e MARCOUX, 2014), interseções podem ser ainda mais perigosas quando os condutores estão em alta velocidade. Geralmente, o aumento na velocidade aumenta o risco de se envolver em um acidente, bem como a gravidade desse acidente.

Pauw et al. (2014b) avaliaram o efeito prévio e posterior, para a segurança de tráfego, da combinação de equipamentos de fiscalização de velocidade e ASV em 253 cruzamentos semaforizados em Flandres, na Bélgica, instalados entre 2002 e 2007. As análises mostraram um aumento não significativo de $5 \%$ do número de feridos, porém com uma redução significativa de quase $14 \%$ para acidentes graves. O número de colisões traseiras aumentou significativamente em $44 \%$. Os autores concluíram que a combinação de câmeras de velocidade e de ASV tem um efeito favorável sobre a segurança do trânsito, em especial sobre acidentes graves, e recomendam que pesquisas futuras examinem as circunstâncias de colisões traseiras e como esse aumento pode ser gerenciado. Por outro lado, não foi possível analisar se a diminuição das colisões laterais deu-se principalmente pela redução do ASV ou da velocidade de condução. 
Vanlaar, Robertson e Marcoux (2014) avaliaram o impacto da fiscalização eletrônica de velocidade e de ASV em Winnipeg. As análises mostraram que, para acidentes relacionados com o ASV, houve uma diminuição de $46 \%$ nos acidentes em ângulo reto em cruzamentos com câmera, mas também um aumento inicial de $42 \%$ nas colisões traseiras. Os autores afirmam que as câmeras de ASV (que só detectam sinais vermelhos) e as que detectam excesso de velocidade e ASV são medidas diferentes, porém os resultados encontrados foram semelhantes (redução em colisões laterais e aumento de colisões traseiras).

\subsubsection{Encerramento de programas de fiscalização eletrônica}

Porter, Johnson e Bland (2013) avaliaram os efeitos do encerramento do programa de fiscalização eletrônica de ASV na Virgínia em locais anteriormente fiscalizados. Eles descobriram que as baixas taxas de ASV nos locais previamente fiscalizados haviam desaparecido após um ano. Como observam esses autores, além de Pulugurtha e Otturu (2014), o encerramento do programa de fiscalização eletrônica por ASV pode aumentar as taxas desse tipo de infração ao longo do tempo.

\subsection{6 Índice de infrações}

Podendo ser dado pela relação entre a quantidade de infrações e a quantidade de veículos que passam em determinado local, o índice de infrações é uma ferramenta importante para comparar diferentes localidades e avaliar a segurança viária.

Bocanegra (2006) analisou os procedimentos para implantação e avaliação do desempenho de lombadas eletrônicas a partir de parâmetros relacionados às variáveis velocidade e acidentes. Dentre as etapas para avaliação do desempenho das lombadas eletrônicas cita-se a relação entre infrações registradas e volume veicular. A relação encontrada foi de 26 infrações a cada dez mil veículos, e o autor menciona a inexistência de estudos que definam um valor referencial para as infrações cometidas em locais fiscalizados com lombadas eletrônicas em áreas urbanas.

Supriyasilp (2003 apud AL-ATAWI, 2014) apresenta os dados visualizados na Tabela 3.1, com taxas de ASV em diferentes países antes da instalação de EFE, obtidos por filmagem das aproximações estudadas. 
Tabela 3.1: Taxas de ASV em diferentes cidades

\begin{tabular}{c|c|c}
\hline Local & $\begin{array}{c}\text { Número de } \\
\text { interseções }\end{array}$ & $\begin{array}{c}\text { Média de infrações por } \\
\mathbf{1 0 . 0 0 0} \text { veículos }\end{array}$ \\
\hline Oxnard, Estados Unidos & 14 & 13,2 \\
\hline Fairfax, Estados Unidos & 9 & 36,8 \\
\hline Arlington, Estados Unidos & 2 & 30,0 \\
\hline 5 cidades do Texas, Estados Unidos & 5 & 41,0 \\
\hline Melbourne e Victoria, Austrália & 15 & 39,0 \\
\hline Tuscaloosa, Estados Unidos & 3 & 53,0 \\
\hline
\end{tabular}

Fonte: Adaptado de SUPRIYASILP (2003 apud AL-ATAWI, 2014).

Na Arábia Saudita, Al-Atawi (2014) verificou que o índice de veículos que avançam a luz vermelha é de 320 para dez mil veículos, em torno de dez vezes maior que a frequência de violações de luz vermelha observada em outros países.

É interessante citar que, em recente lei aprovada na cidade de Jedá, na Arábia Saudita, quem for flagrado cometendo a infração de avançar o sinal vermelho do semáforo será, além de multado - como já acontece -, preso por 24 horas (BBC BRASIL, 2014).

De acordo com Bonneson, Zimmerman e Brewer (2002), várias medidas são utilizadas para quantificar os eventos de ASV. As medidas mais comuns incluem: "percentual dos ciclos com um ou mais avanços de sinal", "taxa de avanço de sinal por hora" e "percentual dos veículos que avançam o sinal". Essas medidas são todas baseadas na frequência de ASV, na exposição (por hora, por ciclo, por veículo) ou localização (por faixa, por aproximação ou por interseção).

Os autores avaliaram dois tipos de taxas de ASV em relação à capacidade de fornecer informações úteis sobre a extensão dessa infração em determinado local. A primeira é expressa em eventos de ASV por mil veículos. A segunda taxa representa o número de eventos de ASV por dez mil veículos-ciclos. As experiências típicas de tratamento da interseção encontram valores de três a cinco ASVs por mil veículos e cerca de um avanço por dez mil veículos-ciclos. A taxa por mil veículos varia mais entre os cruzamentos do que a taxa de dez mil veículos-ciclos, porque não inclui o efeito do número de ciclos na frequência de ASV. 
Como exemplo do trabalho desenvolvido por Bonneson, Zimmerman e Brewer (2002), dada a quantidade de veículos, ciclos e infrações pelo período de contagem de seis horas, tem-se:

Veículos: 2.526 veículos $/ 6$ horas $=421$ veículos/hora

Ciclos: 285 ciclos $/ 6$ horas $=47,5$ ciclos $/$ hora

Infrações de ASV = 13 infrações/6 horas = 2,17 infrações/hora

Número de eventos horários de ASV por dez mil veículos-ciclos = 2,17 / $(421$ x 47,5) x 10.000 = 1,1 infração por dez mil veículos-ciclos.

Entendendo-se que a quantidade de infrações por dez mil veículos ciclos seja a que melhor permite avaliar a extensão do problema e comparar diferentes interseções, haja vista que o número de ciclos influencia a quantidade de vezes que os condutores ficam expostos na mudança de sinalização do amarelo para o vermelho, ainda assim a literatura existente tem trabalhado com a relação quantidade de infração por mil ou dez mil veículos.

Por não dispor de informações históricas em relação ao número de ciclos, o presente estudo aborda o índice de infrações como a relação entre a quantidade de infrações aplicadas e a quantidade de veículos que passam pelo local.

\subsection{FATORES QUE INFLUENCIAM A REDUÇÃO DE INFRAÇÕES POR AVANÇO DE SINAL}

Al-Atawi (2014) avaliou as características de infrações de ASV em 38 cruzamentos na cidade de Tabuk, na Arábia Saudita, usando câmeras de vídeo. A análise estatística revela que número de aproximações, velocidade, largura da via, velocidade na via transversal e largura do cruzamento afetam significativamente a violação de luz vermelha. A análise de regressão indicou que a largura da via, o tempo de vermelho e a velocidade são os fatores mais importantes que afetam o avanço de luz vermelha.

Bonneson, Zimmerman e Brewer (2002) dividem o ASV de acordo com a decisão do condutor em dois tipos de eventos:

- Evitável: o condutor acredita que é possível parar com segurança, mas decide que é no seu melhor interesse avançar a indicação vermelha. Recomendam-se contramedidas de fiscalização. Por exemplo: condutor que está frustrado pela demora excessiva ou condições 
de fluxo congestionadas ou que pode ser indiferente às leis de trânsito. Além do aumento da capacidade da interseção, que pode representar grandes investimentos, contramedidas de fiscalização são susceptíveis de ser o meio mais eficaz de reduzir a inclinação desse condutor de avançar a indicação vermelha.

- Inevitável: o condutor acredita que não é capaz de parar com segurança (por exemplo, em razão de um julgamento ruim ou por estar relativamente em alta velocidade) e conscientemente decide avançar a indicação vermelha, ou não tem consciência da necessidade de parar (por exemplo, está desatento e não percebe a mudança para amarelo). Recomendam-se contramedidas de engenharia, que podem ser mais eficazes para ajudar os condutores a evitar ASVs.

O Quadro 3.1 apresenta os fatores de exposição e de contribuição à frequência de ASV.

Quadro 3.1: Fatores de exposição e de contribuição relacionados ao ASV

\begin{tabular}{|c|c|}
\hline Fatores de exposição & Fatores de contribuição \\
\hline Taxa de fluxo na aproximação & Probabilidade de parar \\
\hline Número de ciclos do semáforo & Duração do intervalo de amarelo \\
\hline Término de fase por tempo de verde máximo & Duração do intervalo de vermelho geral \\
\hline Taxa de fluxo na aproximação conflitante & Tempo de entrada do condutor em conflito \\
\hline
\end{tabular}

Fonte: Adaptado de BONNESON, ZIMMERMAN e BREWER (2002).

Cada um desses fatores é discutido a seguir com base em Bonneson, Zimmerman e Brewer (2002).

\subsubsection{Fatores de exposição}

Referem-se a eventos que expõem os condutores a condições que podem ocasionar ASV: taxa de fluxo na aproximação; número de ciclos do semáforo; término de fase por tempo de verde máximo; taxa de fluxo na aproximação conflitante.

\subsubsection{Taxa de fluxo na aproximação}

Cada veículo na aproximação da intersecção, no início de amarelo, é exposto ao potencial ASV. O número de condutores que avançam o vermelho a cada ciclo do sinal provavelmente vai aumentar à medida que a taxa de fluxo aumenta. 
Dessa forma, para uma mesma via, quanto maior o fluxo na aproximação na mudança do amarelo para o vermelho, teoricamente maior o número de infrações.

\subsubsection{Número de ciclos do sinal}

A frequência de acidentes e de infrações por ASV é amplamente afetada pela frequência com que a indicação amarela é apresentada.

Analisada isoladamente (e desde que não comprometa o atraso na interseção), uma mudança de comprimento do ciclo de $60 \mathrm{~s}$ para $120 \mathrm{~s}$ reduz o número de vezes que o amarelo é apresentado em 50\%. Em teoria, uma redução semelhante na frequência de ASV também deve ser observada.

\subsubsection{Término de fase por tempo de verde máximo}

De acordo com o manual Sinalização semafórica (CONTRAN, 2014), existem basicamente dois tipos de controle proporcionados pela sinalização semafórica: tempo fixo e atuado. $\mathrm{O}$ controle em tempo fixo utiliza planos semafóricos calculados com base em dados de tráfego disponíveis, obtidos por contagens volumétricas e outros levantamentos de campo. Pode ser efetuado com base em um único plano semafórico ou em planos específicos para atender a demanda de tráfego histórica de períodos distintos do dia e de diferentes dias da semana.

O controle de tipo atuado pode ser dividido em semiatuado e totalmente atuado. O primeiro é, em geral, empregado em cruzamentos de vias de grande volume (vias principais) com vias de baixo volume de tráfego (vias secundárias), onde a indicação verde é dada continuamente para os veículos da via principal, sendo interrompida quando detectores implantados nas aproximações da via secundária indicarem a presença de veículos motorizados. O segundo tipo decorre do monitoramento da demanda de tráfego na interseção, mediante a implantação de detectores de tráfego em todas as suas aproximações, permitindo alterações nos tempos dos estágios. O princípio básico do funcionamento em modo totalmente atuado é o da determinação do tempo de verde associado a cada estágio de sinalização, variando entre um valor mínimo e um valor máximo preestabelecidos. Esse tipo de controle pode permitir o ajuste em tempo real dos valores de alguns dos parâmetros de programação, como, por exemplo, a prioridade a ser dada para uma aproximação congestionada. 
Conforme Bonneson, Zimmerman e Brewer (2002), enquanto em um controle de tempo fixo o plano não varia em função da presença de um veículo na aproximação, expondo os condutores à situação de ASV, os sistemas de detecção de extensão de verde podem reduzir a exposição à mudança do amarelo ao utilizar um ou mais detectores localizados antes da intersecção para manter a fase em verde enquanto a aproximação estiver ocupada, até o limite estabelecido de máxima extensão do verde.

\subsubsection{Taxa de fluxo na aproximação conflitante}

Um conflito requer dois ou mais veículos para interagir, um ou mais dos quais têm de tomar uma ação evasiva para evitar uma colisão. Assim, a frequência de conflito é uma função da taxa de fluxo dos movimentos do tráfego conflitantes. Como evidência desse efeito, Mohamedshah et al. (2000 apud BONNESON, ZIMMERMAN e BREWER, 2002) observaram, em um estudo de frequência de acidente por ASV, que colisões em ângulo reto na via principal aumentam com o crescimento do fluxo na via secundária.

Contudo, Bonneson, Zimmerman e Brewer (2002) afirmam que, nos casos de baixo volume de conflito, condutores sentem-se mais seguros em avançar o sinal vermelho, entendendo-se daí como válidas medidas de fiscalização para reduzir o número de infrações.

\subsubsection{Fatores de contribuição}

Referem-se a eventos que contribuem para a ocorrência de ASV: probabilidade de parar; duração do intervalo de amarelo; duração do intervalo de vermelho geral; tempo de entrada do condutor em conflito.

\subsubsection{Probabilidade de parar}

Segundo Bonneson, Zimmerman e Brewer (2002), a probabilidade de parar representa o complexo processo de tomada de decisão que os condutores exibem no início do amarelo. Tal tomada de decisão é afetada pela avaliação do condutor das condições vigentes de tráfego e da via, bem como pela estimativa do condutor das consequências de parar (ou não).

Van der Horst e Wilmink (1986 apud BONNESON, ZIMMERMAN e BREWER, 2002) estudaram esse processo de decisão e descobriram que a propensão de um condutor para parar 
é baseada em três componentes. Esses componentes e os fatores que os influenciam estão listados no Quadro 3.2.

Quadro 3.2: Fatores a serem considerados no processo de decisão

\begin{tabular}{|l|l|}
\hline Componentes do processo de decisão & \multicolumn{1}{|c|}{ Fatores } \\
\hline & Tempo de viagem \\
& Velocidade \\
& Controle atuado \\
Comportamento do condutor & Headway \\
& Coordenação \\
& Greide da aproximação \\
& Intervalo de amarelo \\
\hline \multirow{2}{*}{ Consequências de não parar } & Ameaça de colisão em ângulo reto \\
& Ameaça de multa \\
\hline \multirow{2}{*}{ Consequências de parar } & Ameaça de colisão traseira \\
& Expectativa de atraso \\
\hline
\end{tabular}

Fonte: Adaptado de BONNESON, ZIMMERMAN e BREWER (2002).

De acordo com Bonneson, Zimmerman e Brewer (2002), condutores são menos propensos a parar quando: têm um curto tempo de viagem até o cruzamento; viajam a velocidades mais elevadas; viajam em pelotões; estão em declives acentuados; são confrontados com indicações amarelas relativamente longas; são seguidos de perto; acreditam que a via que estão atravessando tem um fluxo pequeno; há pouca ameaça de fiscalização; há ameaça de colisão traseira; o atraso esperado é longo.

\section{a) Comportamento do condutor}

Como afirmam Bonneson, Zimmerman e Brewer (2002), no caso de um evento "inevitável" de ASV, a resposta do condutor para a indicação amarela é afetada por sua capacidade percebida de parar e sua consciência da necessidade de parar. Um evento "inevitável" é cometido por um condutor que (1) acredita que não é capaz de parar com segurança e conscientemente decide avançar a indicação vermelha, ou (2) não tem consciência da necessidade de parar. Essa habilidade e consciência são influenciadas pelos sete fatores listados no Quadro 3.2. Cada um desses fatores é discutido nos parágrafos seguintes.

Tempo de viagem. Conforme Bonneson, Zimmerman e Brewer (2002), a decisão de um condutor de parar no início de amarelo é baseada, em parte, por sua estimativa de velocidade e distância para a linha de parada. Por meio dessas previsões, o condutor avalia 
sua capacidade de parar e o grau de conforto associados com a parada. Os autores encontraram um intervalo, entre cerca de 2 s e $5 \mathrm{~s}$ do tempo de viagem a partir da linha de retenção do cruzamento, onde os condutores tornam-se coletivamente indecisos sobre a decisão de parar, e que há diferença no comportamento do condutor nos cruzamentos de controle de tempo fixo e atuado.

Velocidade. A decisão de um condutor de parar pode ser distorcida por sua capacidade limitada para estimar o tempo de viagem até o cruzamento em altas velocidades. Allsop et al. (1991 apud BONNESON, ZIMMERMAN e BREWER, 2002) constataram que os condutores tendem a subestimar o tempo real de viagem em cerca de 30\%. No que tange à essa observação, Bonneson et al. (1994 apud BONNESON, ZIMMERMAN e BREWER, 2002) relataram que os condutores em alta velocidade tendem a ser menos susceptíveis de parar do que os condutores em baixa velocidade quando estão no mesmo tempo de viagem a partir da linha de retenção, no início da indicação de amarelo. Esse comportamento sugere que o grau de subestimação do condutor em relação ao seu tempo de viagem aumenta com a velocidade.

Controle atuado. Van der Horst e Wilmink (1986 apud BONNESON, ZIMMERMAN e BREWER, 2002) encontraram evidências de que os condutores que se aproximam de um cruzamento atuado são menos propensos a parar do que quando se aproximam de cruzamento de tempo fixo. Isto sugere que condutores aprendem quais semáforos são atuados e desenvolvem uma expectativa de serviço de como eles viajam através da zona de detecção.

Coordenação. Van der Horst e Wilmink (1986 apud BONNESON, ZIMMERMAN e BREWER, 2002) investigaram a expectativa do condutor associada ao controle atuado para condutores que viajam dentro de pelotões através de uma série de semáforos controlados em rede aberta (controle em corredor). A expectativa é que cada um dos semáforos de que se aproximam permanecerá verde até após a passagem de todo o pelotão pelo cruzamento. $\mathrm{O}$ desejo do condutor de permanecer dentro do pelotão torna-o menos disposto a parar no início da indicação de amarelo.

Greide da aproximação. Chang et al. (1985 apud BONNESON, ZIMMERMAN e BREWER, 2002) examinaram o efeito do greide da aproximação na probabilidade de parar. Os autores descobriram que os condutores em declive eram menos propensos a parar, em um 
determinado tempo de viagem a partir da linha de retenção, do que os condutores em aproximações em nível ou em aclive.

Intervalo de amarelo. Van der Horst e Wilmink (1986 apud BONNESON, ZIMMERMAN e BREWER, 2002) notaram que um longo intervalo de amarelo pode levar a um comportamento ruim, porque os últimos condutores a parar não são "recompensados" com uma indicação vermelha quando chegam à linha de retenção. Na próxima vez que passarem pelo mesmo cruzamento, esses condutores estarão mais inclinados a não parar. Os autores concluíram que os condutores que estão a $4 \mathrm{~s}$ da linha de retenção têm uma probabilidade de 0,5 de parar quando a duração de amarelo é de $3 \mathrm{~s}$; no entanto, eles têm uma probabilidade de apenas 0,34 de parar se a duração de amarelo for de $5 \mathrm{~s}$ ou mais.

Conforme Bonneson e Zimmerman (2004), uma das críticas de aumentar ou diminuir o tempo de amarelo é que os condutores podem se adaptar à mudança de duração de amarelo depois da aplicação da medida. O efeito, chamado de "habituação", é menor a longo prazo do que o período imediatamente posterior à implementação da medida.

Retting, Ferguson e Farmer (2007) sugerem avaliar os efeitos do aumento do amarelo a longo prazo e que alguns condutores podem se adaptar ao aumento da duração de amarelo e continuar a avançar o sinal vermelho.

Headway. Condutores que trafegam por um cruzamento podem estar mais conscientes de veículos imediatamente à frente ou atrás deles do que em relação à indicação luminosa do semáforo. Desse modo, eles estão susceptíveis de serem "arrastados" através do cruzamento por um condutor líder, apesar da indicação de amarelo (ou vermelho). Allsop et al. (1991 apud BONNESON, ZIMMERMAN e BREWER, 2002) constataram que os condutores que estão "acompanhando de perto" - $2 \mathrm{~s}$ ou menos - o progresso do veículo à frente são mais propensos a avançar a indicação vermelha do que os condutores que trafegam livremente.

\section{b) Consequências de não parar}

Inclui uma estimativa do potencial de um acidente em ângulo reto e o potencial de multa.

Ameaça de colisão em ângulo reto. Um condutor ponderando avançar o sinal vermelho pode avaliar a ameaça de um acidente em ângulo reto, estimando o número de 
veículos no fluxo de tráfego conflitante pela visualização da via transversal, bem como recordar sua experiência prévia no mesmo cruzamento. Nesse sentido, um estudo realizado por Baguley (1988 apud BONNESON, ZIMMERMAN e BREWER, 2002) encontrou uma correlação inversa entre a frequência de ASV e o volume diário da via transversal. Seus dados indicaram que os condutores são seis vezes mais propensos a avançar a indicação vermelha quando a rua transversal tem um volume de tráfego diário de dois mil veículos/dia em comparação com um volume de dezessete mil veículos/dia.

Ameaça de ser multado. Van der Horst e Wilmink (1986 apud BONNESON, ZIMMERMAN e BREWER, 2002) observaram que os condutores consideram o potencial de serem multados no momento de decidir se desejam avançar a indicação vermelha. Os resultados de uma pesquisa com condutores realizada por Retting e Williams (2000 apud BONNESON, ZIMMERMAN e BREWER, 2002) corroboram essa posição. Eles descobriram que $46 \%$ dos condutores (em cidades sem fiscalização eletrônica) acreditam que alguém que avança a indicação vermelha é susceptível de receber uma multa. Esse percentual sobe para $61 \%$ em cidades com fiscalização eletrônica.

\section{c) Consequências de parar}

A preocupação do condutor sobre a ameaça de uma colisão traseira ou um longo atraso também é levada em conta na decisão de parar quando se depara com uma indicação de amarelo.

Ameaça de colisão traseira. Condutores que estão sendo seguidos de perto quando ocorre a troca do sinal verde para amarelo podem ser mais relutantes em parar por causa da maior probabilidade de uma colisão traseira. Allsop et al. (1991 apud BONNESON, ZIMMERMAN e BREWER, 2002) observaram que os condutores seguidos de perto (headway menor que $2 \mathrm{~s}$ ) no início do amarelo foram mais propensos a avançar a indicação vermelha. Os autores constataram que, com tempo de viagem de $3 \mathrm{~s}$ até a linha de retenção, cerca de $50 \%$ dos condutores irão parar se a aproximação estiver fluindo livremente e somente $25 \%$ irão parar se estiverem sendo seguidos de perto. No caso de o condutor estar entre dois veículos (líder e seguidor), somente 8\% dos condutores irão parar.

Expectativa de atraso. Uma pesquisa realizada pela Federal Highway Administration (FHWA) (1998 apud BONNESON, ZIMMERMAN e BREWER, 2002) indicou que 66\% dos 
condutores do Texas acreditam que o ASV é ocasionado por condutores que estão com pressa. Zegeer e Deen (1978 apud BONNESON, ZIMMERMAN e BREWER, 2002) observaram dois cruzamentos antes e depois da instalação de um sistema de extensão verde. Os dados indicam que os condutores que viajam nas horas-pico de trânsito são mais propensos ao ASV que durante as outras horas do dia. Essa tendência foi exibida em ambos os períodos, "antes" e "depois". Como os atrasos tendem a ser maiores durante as horas de pico, as tendências sugerem que os condutores podem estar mais inclinados a avançar na indicação de vermelho com o aumento esperado de atraso.

\subsubsection{Duração do intervalo de amarelo}

De acordo com o manual Sinalização semafórica (CONTRAN, 2014), a indicação amarela do semáforo tem como significado indicar o término do direito de passagem. A ação do condutor na via deve ser de parar o veículo, salvo se não for possível imobilizá-lo em condições de segurança.

Conforme Bonneson, Zimmerman e Brewer (2002), a duração do intervalo de amarelo é geralmente reconhecida como um fator-chave que afeta a frequência de ASV e deve basear-se no tempo de percurso do condutor de 85 (ou 90) percentil, com variação de 4,0 s a 5,5 s (maior tempo para aproximações de velocidade mais alta). Dados relatados por Van der Horst e Wilmink (1986 apud BONNESON, ZIMMERMAN e BREWER, 2002) indicam que os intervalos de amarelo superiores a 3,5 s estão associados com percentual mínimo de ASV.

Bonneson e Zimmerman (2004) sugerem que um intervalo de amarelo de 4,2 s é suficiente para $85 \%$ dos condutores pararem. Apenas $15 \%$ dos condutores optam por avançar a indicação de vermelho no início do amarelo e estão na posição "primeiro para parar".

De acordo com o Manual on Uniform Traffic Control Devices (US DEPARTMENT OF TRANSPORTATION, 2006 apud RETTING, FERGUSON e FARMER, 2007), os intervalos de amarelo devem variar entre $3 \mathrm{~s} \mathrm{e} 6 \mathrm{~s}$, e os intervalos mais longos devem ser reservados para aproximações com velocidades de tráfego mais elevadas.

O manual Sinalização semafórica (CONTRAN, 2014) estabelece parâmetros gerais mínimos para o tempo de amarelo em função da velocidade regulamentada da via, conforme a Tabela 
3.2, fixando um intervalo mínimo de $3 \mathrm{~s}$ a $5 \mathrm{~s}$. O cálculo do intervalo de tempo de amarelo é realizado com base no manual Sinalização semafórica (CONTRAN, 2014) quando do cálculo do entreverdes (Apêndice A).

Tabela 3.2: Tempo mínimo de amarelo em relação à velocidade regulamentada

\begin{tabular}{c|c}
\hline Velocidade regulamentada $(\mathbf{k m} / \mathbf{h})$ & Tempo mínimo de amarelo (s) \\
\hline Igual ou inferior a 40 & 3 \\
\hline 50 ou 60 & 4 \\
\hline 70 & 5 \\
\hline
\end{tabular}

Fonte: Adaptado de CONTRAN (2014).

\subsubsection{Duração do intervalo de vermelho geral}

Intervalo de vermelho geral para semáforos veiculares é o intervalo de tempo entre o final do amarelo de um estágio e o início do verde do próximo estágio, com o objetivo de fornecer tempo adicional aos veículos conflitantes antes que o movimento do tráfego seja liberado.

Para Bonneson, Zimmerman e Brewer (2002), um tempo insuficiente de vermelho geral pode contribuir para o aumento dos acidentes em virtude da confusão ou falta de respeito do condutor para com o semáforo. $\mathrm{O}$ intervalo de vermelho geral fornece um grau de proteção em relação a colisões em ângulo reto quando é igual ou superior ao tempo necessário para limpar a interseção do veículo que atravessa o cruzamento.

De acordo com Hallmark, Oneyear e McDonald (2012), o intervalo de vermelho geral é definido como aquele em que todos os sinais em um cruzamento exibem uma fase vermelha para permitir que os veículos que entraram durante o intervalo de amarelo possam sair do cruzamento com segurança antes que a fase verde para o tráfego conflitante seja exibida. Os autores consideram que se um intervalo de vermelho geral já é usado, estender essa fase pode ser outra contramedida possível.

O cálculo do intervalo de tempo de vermelho geral (Apêndice A.2) é realizado com base no manual Sinalização semafórica (CONTRAN, 2014) quando do cálculo do entreverdes. Entende-se que, caso seja adotado um tempo insuficiente, há risco de colisões em ângulo e, caso seja adotado um tempo excessivo, surgem atrasos que podem induzir condutores a desrespeitar a sinalização semafórica. 


\subsubsection{Tempo de entrada do condutor em conflito}

Conforme Bonneson, Zimmerman e Brewer (2002), o condutor líder em um fluxo de tráfego conflitante poderia estar em um dos quatro estados seguintes depois de receber a indicação verde do semáforo, ordenado em risco crescente de conflito:

1) O condutor está parado na linha de retenção e faz uma pausa para verificar se o cruzamento está limpo antes de prosseguir;

2) O condutor está parado na linha de retenção e tenta antecipar o início de verde movimentando-se para frente durante o intervalo de vermelho geral;

3) O condutor está se aproximando do cruzamento, mas desacelera para parar no intervalo de vermelho;

4) O condutor está se aproximando do cruzamento, mas antecipa o início de verde e mantém uma velocidade nominal.

Hulsher (1984 apud BONNESON, ZIMMERMAN e BREWER, 2002) e Chang et al. (1985 apud BONNESON, ZIMMERMAN e BREWER, 2002) descobriram que, mesmo quando um intervalo de vermelho geral não é fornecido, os condutores que estão em primeiro na fila nos estados 1 e 2 necessitam mais do que $1 \mathrm{~s}$ para atingir a trajetória do veículo que está saindo do cruzamento. No entanto, essa proteção não pode ser aplicada em horas noturnas quando os estados 3 ou 4 são susceptíveis de ocorrer.

A fim de avaliar o tempo de entrada do condutor em conflito, como parte da metodologia, foram solicitadas cem notificações de infração aleatórias para cada uma das interseções críticas. O tempo de passagem após o início da indicação vermelha será avaliado também em relação ao tempo de retardo, para verificação do cumprimento da legislação vigente e da análise das contramedidas de engenharia e de fiscalização, tratadas a seguir.

\subsection{CONTRAMEDIDAS DE ENGENHARIA PARA REDUÇÃO DE INFRAÇÕES POR AVANÇO DE SINAL}

Existe uma vasta gama de contramedidas potenciais para o problema de ASV, as quais são geralmente divididas em duas grandes categorias: contramedidas de fiscalização e contramedidas de engenharia (BONNESON, ZIMMERMAN e BREWER, 2002). 
Contramedidas de fiscalização são direcionadas aos condutores para respeitar as leis de trânsito por meio da ameaça de multa e restrição do direito de dirigir. Em contraste, contramedidas de engenharia têm a intenção de reduzir a frequência com que os condutores se encontram em uma posição de decidir se devem avançar ou não a indicação vermelha. A relação entre a categoria da contramedida e o tipo de decisão tomada pelo condutor ao avançar o sinal vermelho é mostrada no Quadro 3.3.

Quadro 3.3: Relação entre categorias de contramedidas e tipo de decisão do condutor

\begin{tabular}{|c|c|c|c|}
\hline Tipo de decisão do & Cenário possível & \multicolumn{2}{|c|}{ Categoria de contramedida } \\
\cline { 3 - 4 } condutor & Engenharia & Fiscalização \\
\hline Evitável & $\begin{array}{c}\text { Congestionado, } \\
\text { ciclo saturado }\end{array}$ & Menos efetiva & Mais efetiva \\
\hline Inevitável & $\begin{array}{c}\text { Condutor incapaz } \\
\text { de parar/desatento }\end{array}$ & Mais efetiva & Menos efetiva \\
\hline
\end{tabular}

Fonte: Adaptado de BONNESON, ZIMMERMAN e BREWER (2002).

Como já citado, a decisão do condutor em avançar o sinal vermelho é "evitável” quando ele acredita ser possível parar com segurança, mas decide que é no seu melhor interesse avançar a indicação vermelha. A decisão de avançar o sinal "inevitável” é aquela em que o condutor acredita que não é capaz de parar com segurança (por exemplo, em razão de um julgamento ruim ou de alta velocidade) e conscientemente decide avançar a indicação vermelha, ou não tem consciência da necessidade de parar (por exemplo, está desatento e não percebe a mudança para amarelo).

De acordo com Bonneson e Zimmerman (2004), contramedidas de engenharia representam um meio útil para combater o problema de ASV porque são passivamente aplicadas e estão no controle direto dos órgãos responsáveis pela sinalização. Bonneson, Zimmerman e Brewer (2002) e Hallmark, Oneyear e McDonald (2012) dividem em três categorias as contramedidas de engenharia: operação do semáforo (Apêndice A), informação ao condutor (Apêndice B) e melhorias físicas (Apêndice C). O Quadro 3.4 apresenta as contramedidas específicas de engenharia por categoria. 
Quadro 3.4: Contramedidas de engenharia para redução de ASV

\begin{tabular}{|c|c|}
\hline $\begin{array}{c}\text { Categoria da } \\
\text { contramedida }\end{array}$ & Contramedida específica \\
\hline \multirow{5}{*}{$\begin{array}{l}\text { Operação do } \\
\text { semáforo } \\
\text { (modificar fase, } \\
\text { tamanho do } \\
\text { ciclo ou } \\
\text { intervalo de } \\
\text { mudança) }\end{array}$} & Aumentar o intervalo de amarelo \\
\hline & Aumentar o intervalo de vermelho geral \\
\hline & Fornecer extensão do verde (detecção prévia) \\
\hline & Melhorar a coordenação semafórica \\
\hline & Melhorar a operação do semáforo (fase, comprimento do ciclo) \\
\hline \multirow{7}{*}{$\begin{array}{l}\text { Informação ao } \\
\text { condutor } \\
\text { (fornecer } \\
\text { informação } \\
\text { prévia ou } \\
\text { melhorar a } \\
\text { exibição) }\end{array}$} & Adequar configuração do elemento de sustentação do semáforo \\
\hline & Utilizar fonte de luz LED \\
\hline & Aumentar a conspicuidade do sinal (anteparo, pestana, estrobo) \\
\hline & Aumentar o tamanho da lente \\
\hline & Adicionar focos semafóricos \\
\hline & Adicionar placa de advertência de semáforo à frente \\
\hline & Usar alerta antecipado para o fim do verde (ou início de amarelo) \\
\hline \multirow{4}{*}{$\begin{array}{l}\text { Melhoria física } \\
\text { (implementar } \\
\text { melhorias de } \\
\text { segurança ou } \\
\text { operacionais) }\end{array}$} & Remover semáforos desnecessários \\
\hline & Aumentar capacidade com faixa de tráfego adicional \\
\hline & Considerar projeto de rotatória para a interseção \\
\hline & Achatar/suavizar curvas horizontais e verticais \\
\hline
\end{tabular}

Fonte: Adaptado de BONNESON, ZIMMERMAN e BREWER (2002) e HALLMARK, ONEYEAR e McDONALD (2012).

O Quadro 3.5, que sintetiza o trabalho de Hallmark, Oneyear e McDonald (2012), aponta vantagens, desvantagens e eficácia de cada uma das contramedidas citadas pelos autores. Quando disponíveis, os fatores de modificação de acidentes (crash modification factors CMF) da FHWA citados pelos autores foram resumidos para a contramedida correspondente.

O CMF é um fator multiplicativo que pode ser usado para estimar o número esperado de acidentes após a implantação de uma contramedida em um determinado local. Por exemplo, se o CMF para Contramedida A é igual a 0,90 e o número anual de acidentes atual é 15, o número esperado de acidentes após a implantação da Contramedida $\mathrm{A}$ é $0,90 \times 15=13,5$ acidentes (uma redução de 1,5 acidente). 
Quadro 3.5: Análise de contramedidas específicas de engenharia para redução de infrações por ASV

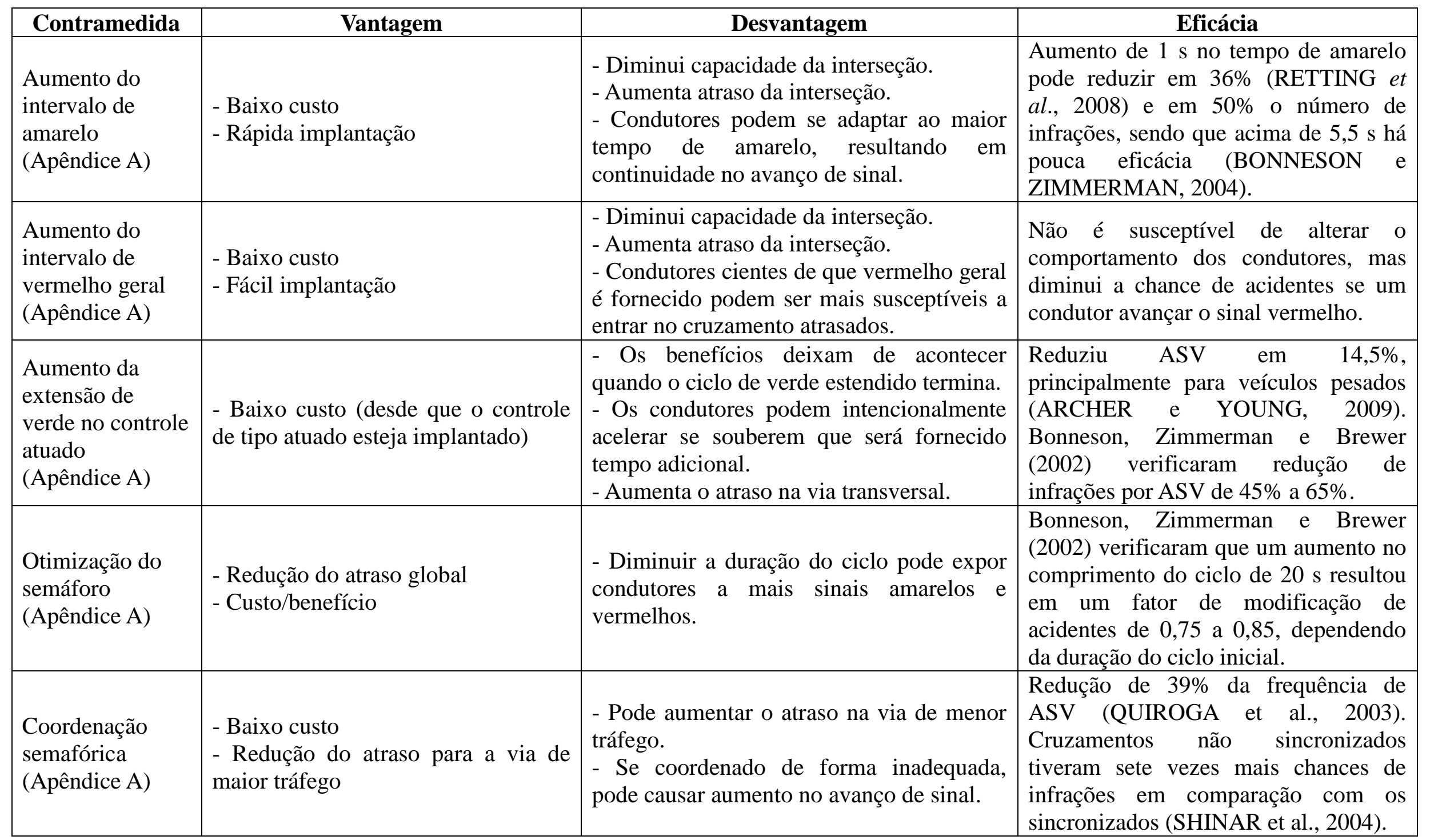


Quadro 3.5: Continuação

\begin{tabular}{|c|c|c|c|}
\hline Contramedida & Vantagem & Desvantagem & Eficácia \\
\hline $\begin{array}{l}\text { Foco semafórico } \\
\text { adicional } \\
\text { (Apêndice B) }\end{array}$ & $\begin{array}{l}\text { - Melhoria da operação do tráfego } \\
\text { - Custo moderado }\end{array}$ & $\begin{array}{l}\text { - Foco adicional para manter. } \\
\text { - Suporte do semáforo pode não ser } \\
\text { adequado para o peso adicional. }\end{array}$ & $\begin{array}{l}\text { Combinação de uma ou mais das } \\
\text { seguintes medidas preventivas: } \\
\text { melhoria no tamanho da lente do sinal, } \\
\text { instalação de novos anteparos, } \\
\text { utilização de fita reflexiva para } \\
\text { anteparos existentes e uso de grupos } \\
\text { focais adicionais. - } 0,93 \text { para todos os } \\
\text { acidentes. - 0,97 para acidentes fatais, } \\
\text { graves e de menor severidade. }\end{array}$ \\
\hline $\begin{array}{l}\text { Configurações de } \\
\text { montagem do } \\
\text { semáforo } \\
\text { (Apêndice B) }\end{array}$ & $\begin{array}{l}\text { - Elementos projetados indicam mais } \\
\text { claramente qual faixa é controlada } \\
\text { por um sinal específico. } \\
\text { - Visibilidade de sinais projetados no } \\
\text { alto é menos frequentemente } \\
\text { prejudicada por veículos de grande } \\
\text { porte. }\end{array}$ & $\begin{array}{l}\text { - Pode ser menos esteticamente agradável } \\
\text { em comparação com colunas. } \\
\text { - Braço projetado e cordoalhas são mais } \\
\text { caros do que colunas simples. }\end{array}$ & $\begin{array}{l}\text { Converter um semáforo de coluna para } \\
\text { um projetado fornece CMF de: } \\
\text { - 0,51 e 0,71 para todos os acidentes } \\
\text { (RODEGERDTS et al., 2004; McGEE } \\
\text { et al., 2002). } \\
\text { - 0,56 para acidentes fatais, graves e } \\
\text { de menor severidade; 0,59 para } \\
\text { colisões traseiras; 0,88 para colisões } \\
\text { em ângulo (RODEGERDTS et al., } \\
\text { 2004). }\end{array}$ \\
\hline $\begin{array}{l}\text { Placa de } \\
\text { advertência de } \\
\text { semáforo à frente } \\
\text { (Apêndice B) }\end{array}$ & $\begin{array}{l}\text { - Baixo custo } \\
\text { - Eficaz em apropriadas aplicações }\end{array}$ & $\begin{array}{l}\text { - Se usada em demasia ou de forma } \\
\text { inadequada, os condutores podem se } \\
\text { dessensibilizar com o sinal e com outros } \\
\text { sinais de alerta. } \\
\text { - Manter sinais adicionais. }\end{array}$ & $\begin{array}{l}\text { Redução de } 44 \% \text { em acidentes em } \\
\text { ângulo reto (POLANIS, 2002). } \\
\text { - CMF de 0,65 para acidentes em } \\
\text { ângulo. }\end{array}$ \\
\hline $\begin{array}{l}\text { Alerta } \\
\text { antecipado para } \\
\text { fim do verde } \\
\text { (Apêndice B) }\end{array}$ & $\begin{array}{l}\text { - Alerta adicional e tempo de reação } \\
\text { - Especialmente eficaz para veículos } \\
\text { de grande porte e comerciais } \\
\text { - Melhoria de relativo baixo custo }\end{array}$ & $\begin{array}{l}\text { - Pode aumentar a zona de dilema. } \\
\text { - Os condutores podem contar com o sinal } \\
\text { em vez de verificar alterações de sinal. }\end{array}$ & $\begin{array}{l}\text { Redução de infrações em cerca de } 40 \% \\
\text { a } 45 \% \text { quando se utiliza um sistema de } \\
\text { alerta antecipado fornecido no final da } \\
\text { fase de verde (MESSER et al., 2004). }\end{array}$ \\
\hline
\end{tabular}


Quadro 3.5: Continuação

\begin{tabular}{|c|c|c|c|}
\hline Contramedida & Vantagem & Desvantagem & Eficácia \\
\hline $\begin{array}{l}\text { Fonte de luz } \\
\text { LED (Apêndice } \\
\text { B) }\end{array}$ & $\begin{array}{l}\text { - Eficiente em termos de energia } \\
\text { (consome } 90 \% \text { menos energia e é } \\
\text { mais brilhante que as lâmpadas } \\
\text { incandescentes tradicionais). } \\
\text { - Mais tempo de vida (6 a } 10 \text { anos } \\
\text { em comparação com } 12 \text { a } 15 \text { meses). } \\
\text { - Redução de falhas de indicação do } \\
\text { semáforo. } \\
\text { - Manutenção menos frequente } \\
\text { reduzindo perturbações no trânsito. } \\
\text { - Maior tempo de operação de } \\
\text { backup da bateria durante quedas de } \\
\text { energia. }\end{array}$ & $\begin{array}{l}\text { - Potencial de brilho pode afetar a visão do } \\
\text { condutor à noite (ITE, 2003). } \\
\text { - Acúmulo de neve (luzes LED não geram } \\
\text { tanto calor como as lâmpadas } \\
\text { incandescentes). }\end{array}$ & $\begin{array}{l}\begin{array}{l}\text { Redução de } 13 \% \text { no número de } \\
\text { infrações } \\
\text { ZIMMERMAN e BREWER, 2002). }\end{array}\end{array}$ \\
\hline $\begin{array}{l}\text { Luzes vermelhas } \\
\text { do semáforo } \\
\text { repetidas } \\
\text { (Apêndice B) }\end{array}$ & $\begin{array}{l}\text { - Chama mais atenção ao sinal } \\
\text { - Melhoria de relativo baixo custo }\end{array}$ & $\begin{array}{l}\text { - Faces vermelhas duplas podem ser } \\
\text { confusas para alguns condutores. }\end{array}$ & $\begin{array}{l}\text { Diminuição de } 33 \% \text { em acidentes de } \\
\text { ângulo reto (POLANIS, 2002). } \\
\text { Srinivasan et al. (2008) observaram } \\
\text { aumento não estatisticamente } \\
\text { significativo (CMF de 1,05). }\end{array}$ \\
\hline $\begin{array}{l}\text { Fase de proteção } \\
\text { de conversão à } \\
\text { esquerda }\end{array}$ & $\begin{array}{l}\text { - Custo baixo para moderado } \\
\text { - Trata outros tipos de acidentes de } \\
\text { conversão à esquerda, além daqueles } \\
\text { referentes aos sinais vermelhos. }\end{array}$ & $\begin{array}{l}\text { - Aumenta o atraso na interseção. } \\
\text { - Impacta somente veículos girando à } \\
\text { esquerda (não é uma solução geral para } \\
\text { ASV). }\end{array}$ & $\begin{array}{l}\text { Redução de } 25 \% \text { e } 70 \% \text { para todos os } \\
\text { acidentes e relacionados à conversão à } \\
\text { esquerda (AGENT et al., 1996). } \\
\text { Fase protegida de conversão à esquerda } \\
\text { forneceu melhor opção para redução de } \\
\text { acidentes (MAZE et al., 1994; } \\
\text { HALLMARK e MUELLER, 2004). } \\
\text { Nenhum dos estudos tratou } \\
\text { especificamente de acidentes por ASV. }\end{array}$ \\
\hline $\begin{array}{l}\text { Distância de } \\
\text { visibilidade } \\
\text { (Apêndice C) }\end{array}$ & - Aborda todos os tipos de acidentes. & $\begin{array}{l}\text { - Muitas vezes envolve altos custos, } \\
\text { especialmente se for necessária } \\
\text { reconstrução. }\end{array}$ & $\begin{array}{l}\text { Redução de todos os acidentes de } 30 \% \text {, } \\
\text { não apenas àqueles relacionados a ASV } \\
\text { (AGENT et al., 1996) }\end{array}$ \\
\hline
\end{tabular}


Quadro 3.5: Continuação

\begin{tabular}{|c|c|c|c|}
\hline Contramedida & Vantagem & Desvantagem & Eficácia \\
\hline $\begin{array}{l}\text { Remover } \\
\text { semáforos } \\
\text { desnecessários } \\
\text { (Apêndice C) }\end{array}$ & $\begin{array}{l}\text { Kay et al. (1980 apud ITE, 2003) } \\
\text { constataram redução do atraso total, } \\
\text { do número de paradas e do consumo } \\
\text { de combustível por veículo. }\end{array}$ & $\begin{array}{l}\text { - Pode não ser aceito pela população. } \\
\text { - Remoção pode ser cara. }\end{array}$ & $\begin{array}{l}\text { Redução de } 24 \% \text { no número total de } \\
\text { acidentes e redução de } 46 \% \text { em } \\
\text { acidentes graves em ângulo reto } \\
\text { (PERSAUD et al., 1997). }\end{array}$ \\
\hline $\begin{array}{l}\text { Rotatória } \\
\text { (Apêndice C) }\end{array}$ & $\begin{array}{l}\text { - Potencial para reduzir a gravidade } \\
\text { dos acidentes (ângulo de entrada e } \\
\text { baixas velocidades). } \\
\text { - Redução do número de pontos de } \\
\text { conflito quando comparado com } \\
\text { cruzamentos semaforizados. }\end{array}$ & $\begin{array}{l}\text { - Pode não acomodar bem pedestres. } \\
\text { - Pode exigir mais direito de passagem que } \\
\text { cruzamentos padrão. } \\
\text { - Capacidade limitada. } \\
\text { - Novos usuários necessitam de educação e } \\
\text { experiência para dirigir de forma eficaz. } \\
\text { - É caro para construir. }\end{array}$ & $\begin{array}{l}\text { Redução de } 35 \% \text { no total de acidentes } \\
\text { e redução de } 74 \% \text { em acidentes com } \\
\text { feridos (PERSAUD et al., 2001). } \\
\text { Redução de } 48 \% \text { em todos os acidentes } \\
\text { e de } 77,7 \% \text { em acidentes com fatais e } \\
\text { feridos (RODEGERDTS } \text { et al., 2007). }\end{array}$ \\
\hline
\end{tabular}

Fonte: Adaptado de HALLMARK, ONEYEAR e McDONALD (2012).

Nota: Todas as fontes citadas foram consultadas por Hallmark, Oneyear e McDonald (2012). 


\subsection{Causas de avanço de sinal e contramedidas}

Bonneson, Zimmerman e Brewer (2002) elaboraram quadros em que possíveis causas de ASV podem ser relacionadas com as categorias de contramedidas de engenharia e fiscalização. Além disso, apresentaram uma classificação de decisões do condutor em evitáveis e inevitáveis, sintetizados neste trabalho em um único quadro (Quadro 3.6).

Quadro 3.6: Tipo de decisão do condutor e contramedidas de engenharia e fiscalização por causa possível de ASV

\begin{tabular}{|c|c|c|c|c|c|c|}
\hline \multirow{2}{*}{$\begin{array}{c}\text { Possível causa de } \\
\text { ASV }\end{array}$} & \multicolumn{3}{|c|}{$\begin{array}{c}\text { Categorias de contramedidas de } \\
\text { engenharia }\end{array}$} & \multirow{2}{*}{ Fiscalização } & \multirow{2}{*}{ Inevitável } & \multirow{2}{*}{ Evitável } \\
\hline & $\begin{array}{l}\text { Operação } \\
\text { semáforo }\end{array}$ & $\begin{array}{l}\text { Informação } \\
\text { ao condutor }\end{array}$ & $\begin{array}{l}\text { Melhoria } \\
\text { física }\end{array}$ & & & \\
\hline $\begin{array}{l}\text { Congestionamento } \\
\text { ou atraso excessivo }\end{array}$ & $X$ & & $X$ & & & $X$ \\
\hline $\begin{array}{l}\text { Desconsideração } \\
\text { para com o sinal } \\
\text { vermelho }\end{array}$ & & & & $X$ & & $X$ \\
\hline $\begin{array}{l}\text { Julgado seguro em } \\
\text { razão do baixo } \\
\text { volume de conflito }\end{array}$ & & & $X$ & $X$ & & $X$ \\
\hline $\begin{array}{l}\text { Julgado seguro } \\
\text { porque a via } \\
\text { transversal é } \\
\text { estreita }\end{array}$ & & & & $X$ & & $X$ \\
\hline $\begin{array}{l}\text { Julgado seguro por } \\
\text { seguir menos de } 2 \\
\text { segundos atrás do } \\
\text { veículo da frente }\end{array}$ & & & & $X$ & & $X$ \\
\hline $\begin{array}{l}\text { Expectativa de } \\
\text { verde quando em } \\
\text { pelotão }\end{array}$ & $X$ & & & & $X$ & $X$ \\
\hline $\begin{array}{l}\text { Inclinação mais } \\
\text { acentuada do que o } \\
\text { esperado }\end{array}$ & $X$ & & & & $X$ & \\
\hline $\begin{array}{l}\text { Velocidade maior } \\
\text { do que o limite } \\
\text { regulamentado }\end{array}$ & $X$ & & & & $X$ & $X$ \\
\hline $\begin{array}{l}\text { Incapaz de parar } \\
\text { (desaceleração } \\
\text { excessiva) }\end{array}$ & $X$ & & & & $X$ & \\
\hline $\begin{array}{l}\text { Pressionado de } \\
\text { perto por veículo } \\
\text { seguidor }\end{array}$ & $\mathrm{X}$ & & & & $X$ & \\
\hline $\begin{array}{l}\text { Veículo alto à } \\
\text { frente bloqueando } \\
\text { a vista }\end{array}$ & & $X$ & & & $X$ & \\
\hline
\end{tabular}


Quadro 3.6: Continuação

\begin{tabular}{|c|c|c|c|c|c|c|}
\hline \multirow{2}{*}{$\begin{array}{c}\text { Possível causa de } \\
\text { ASV }\end{array}$} & \multicolumn{3}{|c|}{$\begin{array}{c}\text { Categorias de contramedidas de } \\
\text { engenharia }\end{array}$} & \multirow{2}{*}{ Fiscalização } & \multirow{2}{*}{ Inevitável } & \multirow{2}{*}{ Evitável } \\
\hline & $\begin{array}{l}\text { Operação } \\
\text { semáforo }\end{array}$ & $\begin{array}{l}\text { Informação } \\
\text { ao condutor }\end{array}$ & $\begin{array}{l}\text { Melhoria } \\
\text { física }\end{array}$ & & & \\
\hline $\begin{array}{l}\text { Inesperado, } \\
\text { primeiro semáforo } \\
\text { encontrado }\end{array}$ & & $X$ & & & $X$ & \\
\hline $\begin{array}{l}\text { Não distraído, só } \\
\text { não viu o sinal }\end{array}$ & & $X$ & & & $X$ & \\
\hline $\begin{array}{l}\text { Distraído e não viu } \\
\text { semáforo de } \\
\text { trânsito }\end{array}$ & & $X$ & & & $X$ & \\
\hline $\begin{array}{l}\text { Visão restrita do } \\
\text { semáforo }\end{array}$ & & $\mathrm{X}$ & $X$ & & $X$ & \\
\hline $\begin{array}{l}\text { Exibição confusa } \\
\text { do sinal }\end{array}$ & & $X$ & & & $X$ & \\
\hline
\end{tabular}

Fonte: Adaptado de BONNESON, ZIMMERMAN e BREWER (2002).

Ao analisar-se o Quadro 3.6, convém observar que, para a causa de infração classificada como evitável "congestionamento ou atraso excessivo", Bonneson, Zimmerman e Brewer (2002) optaram por destacar a viabilidade e suficiência de medidas de engenharia na redução do número de infrações, assim como nas causas classificadas conjuntamente como evitáveis e inevitáveis "expectativa de verde quando em pelotão" e "velocidade maior do que o limite regulamentado".

Contramedidas de fiscalização são mais efetivas quando as decisões do condutor acerca de ASV são evitáveis. Ainda que o presente trabalho adote como estudo de caso interseções que já estão sendo fiscalizadas eletronicamente, entende-se que as contramedidas de engenharia citadas na revisão da literatura visam não só contribuir para a redução do número de infrações (em contraponto a se buscar essa redução via medidas de fiscalização), como também a fiscalização só pode ser realizada em locais com características físicas e de controle semafórico que permitam ao condutor evitar a infração.

Desta forma, é possível concluir que a fiscalização de ASV, incluindo a eletrônica, deve ser precedida da adoção de medidas de engenharia que tornem evitável o ASV. 


\subsection{CÁLCULO DO TEMPO DE RETARDO}

Conforme citado no Capítulo 2, a Portaria Denatran no 16/2004 (DENATRAN, 2004) estabelece que o valor do tempo de retardo deve ser justificado para cada local fiscalizado por sistema automático não metrológico para a infração de ASV. Ainda que não se classifique como uma contramedida para a redução desse tipo de infração, o tempo de retardo afeta a quantidade de infrações registradas pelos equipamentos segundo os ditames da legislação brasileira e deve ser rigorosamente observado.

A Portaria Denatran no 16/2004 estabelece que o tempo de retardo é o período de tempo, após o início do sinal vermelho fiscalizado, em que o sistema automático não metrológico de fiscalização de ASV permanece inibido ao registro da imagem do veículo. O tempo de retardo deve considerar as situações específicas de cada local fiscalizado, de forma que seja assegurado o registro da imagem somente de veículos que tenham recebido a indicação luminosa vermelha antes da faixa de retenção da aproximação fiscalizada.

Em atendimento à essa norma, Filizola, Pelisson e Silva (2014) propuseram um método para o cálculo do tempo de retardo com base na equação de Torricelli para movimento retilíneo uniformemente variado, verificando a influência de curvas próximas na desaceleração dos veículos.

As variáveis estudadas são:

a) Velocidade regulamentada $\left(V_{r}\right)$ para o local fiscalizado em $\mathrm{km} / \mathrm{h}$.

b) Velocidade praticada $\left(V_{p}\right)$ obtida com o estudo do 85 percentil em $\mathrm{km} / \mathrm{h}$.

c) Velocidade de projeto da curva de conversão $\left(\mathrm{V}_{\mathrm{c}}\right)$ em $\mathrm{km} / \mathrm{h}$. Havendo conversão próxima do ponto fiscalizado, ela poderá influenciar a velocidade dos veículos que passam pela linha de retenção (LR). Não sendo possível obter o valor de $\mathrm{V}_{\mathrm{c}}$, o Manual de projeto de interseções do Departamento Nacional de Infraestrutura de Transportes DNIT (2005 apud FILIZOLA, PELISSON e SILVA, 2014) recomenda utilizar $\mathrm{V}_{\mathrm{c}}=15$ $\mathrm{km} / \mathrm{h}$.

d) Distância $\left(D_{r}\right)$ medida, em metros, a partir do final da linha de retenção até o início da curva. 
e) Distância de influência da conversão na velocidade em relação à linha de retenção $\left(D_{i}\right)$. A presença de conversão e sua distância da linha de retenção podem influenciar a velocidade adotada $\left(\mathrm{V}_{\mathrm{a}}\right)$ para o cálculo do tempo de retardo.

É necessário tomar como base a equação de Torricelli para obtenção do valor de $D i$,

$$
V^{2}=V_{0}^{2}+2 \cdot a \cdot \Delta S
$$

Equação 3.1

em que:

$V=V_{c}$

$V_{0}$ será $V_{k}$, e $V_{k}$ será a menor velocidade entre $V_{r}$ e $V_{p}$

$\Delta S=D_{i}$

Cabe observar que Filizola, Pelisson e Silva (2014) adotam, como a máxima taxa de frenagem admissível em função das características dos veículos e da via, $a=-1,47 \mathrm{~m} / \mathrm{s}^{2}$, recomendada pelo manual Sinalização horizontal (CONTRAN, 2007b). Todavia, foi adotado para a equação acima $a=-3,0 \mathrm{~m} / \mathrm{s}^{2}$, o que é recomendado pelo manual Sinalização semafórica (CONTRAN, 2014).

Convertendo-se os dados para $\mathrm{km} / \mathrm{h}, D_{i}$ é calculado como:

$$
D i=\left(\frac{V_{k}^{2}-V_{c}^{2}}{77,8}\right)
$$

Se $D_{r} \geq D_{i}, V_{a}$ será $V_{k}$.

Se $D_{r}<D_{i}, V_{a}$ deve ser calculada pela fórmula:

$$
V_{a}=\sqrt{V_{k}^{2}-77,8 \times D_{r}}
$$

A distância $(D)$ que o veículo de projeto deve percorrer até sair da zona de detecção do sistema automático não metrológico de fiscalização deve ser a soma da distância $(d)$ medida do final da linha de retenção até o final do laço indutivo mais distante, ou até o final da zona de detecção, mais o comprimento do veículo de projeto ou tipo (VT). Assim:

$$
D=d+V T
$$


Filizola, Pelisson e Silva (2014) recomendam adotar o comprimento do veículo de projeto ou tipo conforme o Manual de projeto geométrico de travessias urbanas do DNIT, de 2010, que seria de 5,8 m para veículo de passeio, 9,1 m para veículo comercial e 12,2 m para ônibus, em interseções urbanas.

Assim, a fórmula abaixo fornece o valor do tempo de retardo em segundos, devendo, conforme consta no Art. $6^{\circ}$, inciso III, da Portaria Denatran n 16/2004 (DENATRAN, 2004), ficar entre zero e $5 \mathrm{~s}$ e com casas decimais arredondadas para o próximo valor inteiro.

$$
T_{r}=\frac{3,6 \times D}{V_{a}}
$$

Por fim, cabe observar que quanto menor a velocidade adotada, maior será o tempo de retardo calculado. Isso implica que a adoção da velocidade regulamentada poderia representar autuação para condutores trafegando na velocidade mínima permitida para a via (metade da máxima regulamentada) que cruzassem a linha de retenção ainda no amarelo. Por outro lado, caso seja adotada a velocidade mínima permitida, condutores trafegando na velocidade máxima regulamentada poderiam cruzar a linha de retenção na indicação luminosa vermelha sem serem autuados.

No presente trabalho será adotada a velocidade máxima regulamentada, com a observação de que o órgão de trânsito deve ser capaz de identificar o posicionamento dos veículos no momento da mudança da indicação luminosa amarela para vermelha. 


\section{METODOLOGIA}

Segundo Bonneson, Zimmerman e Brewer (2002), o tratamento adequado do problema de ASV requer diagnóstico cuidadoso para assegurar que um problema realmente existe. Deve-se realizar um levantamento do local para quantificar a frequência de infrações e acidentes associados, identificar as condições que podem contribuir para essas ocorrências e, caso estas sejam consideradas excessivas, avaliar uma série de contramedidas de engenharia quanto à sua aplicabilidade e eficácia. As contramedidas mais promissoras devem, então, ser implementadas e uma avaliação de acompanhamento deve ser conduzida para determinar se o ASV e acidentes relacionados foram reduzidos.

De acordo com o ITE (2003 apud HALLMARK, ONEYEAR e McDONALD, 2012), cinco passos são necessários para identificar problemas de segurança de infrações por ASV: constatar a existência de problema de ASV; conduzir uma análise para investigar as causas do problema; identificar contramedidas potenciais; determinar a contramedida adequada e a relação custo-benefício; implantar a contramedida na interseção. Ainda que não tenha sido citado, entende-se como implícito no quinto passo o monitoramento da interseção para avaliação da eficácia das contramedidas implantadas. Observa-se também que a metodologia do ITE considera que o local crítico pode não dispor de contramedidas de fiscalização, diferentemente do que ocorre com as interseções avaliadas no presente trabalho.

A partir da metodologia proposta pelo ITE, o presente estudo, com base nas informações obtidas por sistemas automáticos não metrológicos de fiscalização no Distrito Federal, no período de janeiro de 2009 a dezembro de 2013, conforma-se com as etapas 1, 2 e 3 a seguir, considerando que a contramedida de fiscalização já tenha sido adotada.

1. Identificação das interseções dotadas de EFEs de ASV que apresentam índice de infração com valores extremos e/ou discrepantes

2. Análise das características físicas e operacionais das interseções selecionadas, identificando fatores relacionados ao elevado índice de infração.

3. Identificação de contramedidas potenciais para a solução dos problemas detectados.

A identificação das interseções com problemas de ASV deu-se com base nos dados do índice de infrações aplicadas (relação entre quantidade de infrações aplicadas e quantidade de 
veículos que passam no local), bem como no uso da ferramenta estatística box plot para identificar pontos discrepantes (outliers) e pontos extremos.

\subsection{FERRAMENTA ESTATÍSTICA BOX PLOT}

Diante da premissa de que o condutor possui um comportamento padrão frente à fiscalização eletrônica, procura-se identificar nos dados obtidos os locais que dificultam a obediência à sinalização, representados pela alta relação entre infrações aplicadas e quantidade de veículos.

A fim de classificar os equipamentos em ordem decrescente pelo índice de infrações aplicadas, para a seleção das interseções críticas, utilizou-se a ferramenta estatística box plot, criada por John Tukey em 1997 (MEDRI, 2011), que possibilita identificar valores discrepantes (ou outliers) e extremos em uma dada distribuição.

Com o objetivo de caracterizar valores extremos, que são aqueles muito afastados do centro da distribuição, tanto para cima quanto para baixo, o box plot apresenta a dispersão dos dados por meio de cinco medidas-resumo: o menor valor $\left(\mathrm{x}_{1}\right)$, os quartis $\left(\mathrm{Q}_{1}, \mathrm{Q}_{2}\right.$ e $\left.\mathrm{Q}_{3}\right)$ e o maior valor $\left(\mathrm{x}_{\mathrm{n}}\right)$, importantes para se observar a posição, dispersão e assimetria da distribuição.

De acordo com Medri (2011), o box plot é a forma de representar graficamente os dados da distribuição de uma variável quantitativa em função de seus parâmetros. Na sua construção são considerados os quartis e os limites da distribuição, permitindo uma visualização do posicionamento da distribuição na escala da variável. A Figura 4.1 apresenta um esquema sintetizado para a construção do box plot.

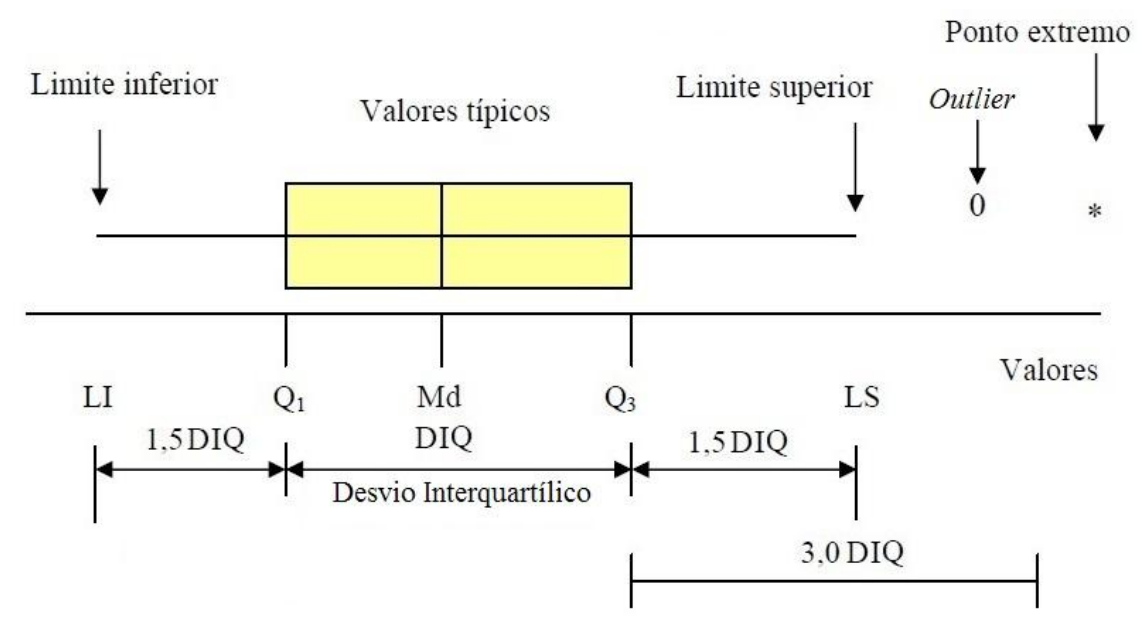

Figura 4.1: Esquema para construção do box plot

Fonte: Adaptado de MEDRI (2011). 
Estas são as propriedades da ferramenta box plot:
a) A caixa contém $50 \%$ da distribuição.
b) A parte superior é Q3 e a inferior é Q1.
c) A mediana, Q2, está dentro da caixa.
d) A diferença interquartílica (DIQ) = Q3 - Q1 (valores típicos da distribuição).
e) $\quad$ Limite superior $=\mathrm{Q} 3+(1,5 \times \mathrm{DIQ})$.
f) $\quad$ Limite inferior $=\mathrm{Q} 1-(1,5 \times \mathrm{DIQ})$.
g) Outlier: entre o limite superior e Q3 + (3,0 $\times$ DIQ $)$ ou entre o limite inferior e Q1 - $(3,0 \times \mathrm{DIQ})$.

h) Ponto extremo: acima de Q3 + (3,0 × DIQ) ou abaixo de Q1 - (3,0 × DIQ).

\subsection{DADOS COLETADOS DOS EQUIPAMENTOS DE FISCALIZAÇÃO ELETRÔNICA}

\subsubsection{Identificação das interseções com maiores índices de infrações}

Os dados coletados pelos sistemas não metrológicos de fiscalização eletrônica (infração e movimentação) referem-se ao período de janeiro de 2009 a dezembro de 2013, disponíveis no Sig-Detran/DF e trabalhados em formato de planilha eletrônica.

Na Tabela 4.1, é possível visualizar a organização dos dados mensais, que englobam infrações aplicadas e não aplicadas, total de infrações, velocidade regulamentada, quantidade de veículos por intervalo de velocidade e total de veículos.

Esclarece-se que as infrações não aplicadas são aquelas em que não é emitida a notificação de autuação. Dentre os motivos dessa não notificação pode-se citar: placa ilegível ou suja, ausência de placa, excesso ou ausência de iluminação, ausência de foco, não enquadramento na foto, encobrimento, veículo oficial, ${ }^{2}$ placa não consta ou não confere com banco de dados, dúvida, duplicidade, cancelamento por auditoria etc.

\footnotetext{
${ }^{2}$ Presume-se que um veículo oficial que avança o sinal vermelho se encontra em situação de atendimento de emergência, como ocorre com corpo de bombeiros e polícia militar.
} 
Tabela 4.1: Exemplo de dados de equipamentos de ASV referentes a novembro/2012

\begin{tabular}{|c|c|c|c|c|c|c|c|c|c|c|c|c|c|c|}
\hline \multirow{2}{*}{ PONTO } & \multicolumn{3}{|c|}{ INFRAÇÕES } & \multirow{2}{*}{$\begin{array}{c}\text { Velocidade } \\
\text { Regulamentada }\end{array}$} & \multicolumn{9}{|c|}{ QUANTIDADE DE VEÍCULOS POR FAIXA DE VELOCIDADE } & \multirow{2}{*}{ Total Veículos } \\
\hline & Aplicadas & Não aplicadas & Total Infrações & & $0-20$ & $20-40$ & $40-50$ & $50-60$ & $60-70$ & $70-80$ & $80-90$ & $90-100$ & $>100$ & \\
\hline ASV001 & 571 & 1 & 572 & 60 & 8.694 & 93.543 & 141.045 & 214.458 & 8.147 & 319 & 55 & 13 & 9 & 466.283 \\
\hline ASV002 & 462 & 1 & 463 & 60 & 7.908 & 91.368 & 117.837 & 160.383 & 5.262 & 160 & 16 & 7 & 2 & 382.943 \\
\hline ASV005 & 150 & 0 & 150 & 50 & 33.088 & 164.389 & 71.444 & 3.456 & 85 & 2 & 1 & & & 272.465 \\
\hline ASV011 & 261 & 0 & 261 & 60 & 16.605 & 234.517 & 367.595 & 164.999 & 3.226 & 129 & 17 & 1 & 2 & 787.091 \\
\hline ASV012 & 109 & 0 & 109 & 60 & 87.238 & 412.599 & 275.936 & 123.126 & 3.970 & 442 & 92 & 54 & 70 & 903.527 \\
\hline ASV013 & 273 & 0 & 273 & 40 & 37.229 & 81.769 & 1.311 & 68 & & & & & & 120.377 \\
\hline ASV014 & 17 & 0 & 17 & 60 & 23.375 & 91.999 & 10.911 & 1.659 & 59 & 4 & & & & 128.007 \\
\hline ASV015 & 267 & 3 & 270 & 60 & 70.493 & 228.027 & 5.137 & 54 & 4 & & & & & 303.715 \\
\hline ASV016 & 84 & 3 & 87 & 60 & 48.642 & 316.588 & 227.632 & 101.279 & 1.872 & 81 & 30 & 12 & 11 & 696.147 \\
\hline ASV017 & 238 & 1 & 239 & 60 & 65.914 & 342.590 & 188.513 & 29.191 & 337 & 68 & 16 & 6 & & 626.635 \\
\hline ASV018 & 175 & 1 & 176 & 60 & 22.138 & 200.630 & 276.314 & 99.457 & 1.550 & 57 & 21 & 8 & & 600.175 \\
\hline ASV019 & 93 & 0 & 93 & 60 & 17.947 & 191.994 & 239.215 & 101.420 & 1.623 & 120 & 41 & 23 & 9 & 552.392 \\
\hline ASV020 & 120 & 0 & 120 & 60 & 51.052 & 271.862 & 244.441 & 91.803 & 1.083 & 56 & 12 & 5 & 2 & 660.316 \\
\hline ASV021 & 103 & 0 & 103 & 60 & 7.059 & 44.916 & 14.145 & 4.849 & 185 & 23 & 2 & 1 & & 71.180 \\
\hline ASV026 & 689 & 3 & 692 & 60 & 19.939 & 201.040 & 225.247 & 212.935 & 6.303 & 260 & 35 & 10 & 3 & 665.772 \\
\hline ASV027 & 410 & 1 & 411 & 60 & 8.687 & 89.630 & 102.252 & 65.478 & 4.789 & 162 & 24 & 13 & 5 & 271.040 \\
\hline ASV028 & 202 & 0 & 202 & 60 & 11.200 & 86.790 & 114.759 & 101.286 & 2.212 & 111 & 8 & 5 & 1 & 316.372 \\
\hline ASV029 & 241 & 1 & 242 & 60 & 7.884 & 50.731 & 56.209 & 93.235 & 4.161 & 104 & 12 & 5 & 5 & 212.346 \\
\hline ASV030 & 341 & 1 & 342 & 60 & 32.889 & 186.926 & 182.458 & 75.751 & 1.269 & 48 & 3 & 1 & & 479.345 \\
\hline ASV031 & 219 & 0 & 219 & 60 & 17.528 & 197.605 & 126.032 & 27.775 & 262 & 7 & 2 & & 1 & 369.212 \\
\hline ASV032 & 87 & 1 & 88 & 60 & 15.000 & 207.909 & 168.484 & 82.633 & 1.059 & 48 & 8 & 2 & & 475.143 \\
\hline ASV033 & 194 & 3 & 197 & 60 & 15.800 & 280.463 & 296.389 & 152.216 & 2.257 & 119 & 37 & 10 & 8 & 747.299 \\
\hline ASV034 & 194 & 0 & 194 & 60 & 34.735 & 231.894 & 365.431 & 127.743 & 1.339 & 73 & 25 & 8 & 2 & 761.250 \\
\hline ASV035 & 566 & 1 & 567 & 60 & 35.333 & 283.351 & 254.357 & 168.997 & 3.991 & 199 & 35 & 16 & 8 & 746.287 \\
\hline ASV036 & 663 & 5 & 668 & 60 & 58.968 & 712.992 & 269.926 & 208.028 & 8.552 & 361 & 71 & 17 & 9 & 1.258 .924 \\
\hline ASV037 & 662 & 5 & 667 & 60 & 60.540 & 527.551 & 330.181 & 234.638 & 4.356 & 239 & 66 & 15 & 11 & 1.157 .597 \\
\hline ASV042 & 359 & 0 & 359 & 60 & 8.088 & 44.345 & 122.858 & 185.191 & 5.358 & 139 & 14 & 4 & 2 & 365.999 \\
\hline ASV043 & 270 & 1 & 271 & 60 & 10.621 & 257.901 & 140.719 & 58.780 & 1.886 & 50 & 4 & 2 & 2 & 469.965 \\
\hline ASV044 & 185 & 1 & 186 & 50 & 48.598 & 113.419 & 24.905 & 1.431 & 26 & & 1 & & & 188.380 \\
\hline ASV045 & 169 & 1 & 170 & 60 & 5.783 & 229.471 & 10.942 & 170 & 5 & & 1 & & & 246.372 \\
\hline ASV046 & 461 & 0 & 461 & 60 & 5.080 & 40.723 & 103.253 & 154.619 & 6.981 & 243 & 42 & 8 & 10 & 310.959 \\
\hline ASV047 & 137 & 0 & 137 & 60 & 6.199 & 62.041 & 91.062 & 124.389 & 5.042 & 107 & 21 & 5 & 4 & 288.870 \\
\hline
\end{tabular}

Fonte: Dados trabalhados pelo autor com informações do Sig-Detran/DF. 
Os dados foram organizados de forma a expor o histórico de cada um dos equipamentos, obtendo-se ao final a média mensal das infrações aplicadas, a quantidade de veículos e o índice de infrações aplicadas (relação entre a quantidade de infrações aplicadas e a quantidade de veículos).

Nos meses em que o equipamento deixou de funcionar - em que houve, por exemplo, rompimento do laço indutivo - ou o arquivo infração não foi enviado - o laudo de aferição estava vencido, por exemplo -, não foi possível obter o índice de infrações aplicadas. Para os casos de inconsistências em um determinado mês na série histórica, o índice de infrações aplicadas calculado foi desconsiderado.

A Tabela 4.2 apresenta como exemplo a série histórica do equipamento ASV 121, que apresentou inconsistências (destaque em amarelo) no número de veículos (dezembro/2012) e no número de infrações aplicadas (novembro/2013), que foram sanadas com a exclusão dos dados (destaque em verde). De agosto a outubro de 2013, ainda que tenha sido registrada a movimentação, o arquivo infração não foi gerado pelo equipamento, o que impediu a obtenção do índice de infrações desses meses (destaque em vermelho). 
Tabela 4.2: Relação mensal de infrações aplicadas pela quantidade de veículos, de janeiro/2009 a dezembro/2013

\begin{tabular}{|c|c|c|c|}
\hline \multicolumn{4}{|c|}{ ASV121 } \\
\hline Data & $\begin{array}{l}\text { Infrações } \\
\text { Aplicadas }\end{array}$ & $\begin{array}{c}\text { Total } \\
\text { Veículos }\end{array}$ & $\begin{array}{l}\text { Índice de } \\
\text { Infrações }\end{array}$ \\
\hline jan/09 & 147 & 31.436 & $0,47 \%$ \\
\hline fev/09 & 193 & 32.184 & $0,60 \%$ \\
\hline $\mathrm{mar} / 09$ & 281 & 42.440 & $0,66 \%$ \\
\hline abr/09 & 295 & 37.281 & $0,79 \%$ \\
\hline $\mathrm{mai} / 09$ & 281 & 37.572 & $0,75 \%$ \\
\hline jun/09 & 350 & 31.802 & $1,10 \%$ \\
\hline jul/09 & 273 & 28.699 & $0,95 \%$ \\
\hline ago/09 & 188 & 28.355 & $0,66 \%$ \\
\hline set/09 & 296 & 38.400 & $0,77 \%$ \\
\hline out/09 & 243 & 33.862 & $0,72 \%$ \\
\hline nov/09 & 223 & 30.590 & $0,73 \%$ \\
\hline $\mathrm{dez} / 09$ & 212 & 21.038 & $1,01 \%$ \\
\hline jan/10 & 138 & 27.390 & $0,50 \%$ \\
\hline $\mathrm{fev} / 10$ & 178 & 27.311 & $0,65 \%$ \\
\hline $\mathrm{mar} / 10$ & 236 & 37.767 & $0,62 \%$ \\
\hline $\mathrm{abr} / 10$ & 291 & 30.620 & $0,95 \%$ \\
\hline $\mathrm{mai} / 10$ & 258 & 32.243 & $0,80 \%$ \\
\hline jun/10 & 302 & 34.149 & $0,88 \%$ \\
\hline jul/10 & 190 & 34.163 & $0,56 \%$ \\
\hline ago/10 & 300 & 36.781 & $0,82 \%$ \\
\hline set/10 & 300 & 31.632 & $0,95 \%$ \\
\hline out/10 & 229 & 34.479 & $0,66 \%$ \\
\hline nov $/ 10$ & 257 & 29.097 & $0,88 \%$ \\
\hline dez/10 & 239 & 31.291 & $0,76 \%$ \\
\hline jan/11 & 229 & 28.030 & $0,82 \%$ \\
\hline fev/11 & 153 & 27.824 & $0,55 \%$ \\
\hline $\mathrm{mar} / 11$ & 232 & 31.323 & $0,74 \%$ \\
\hline $\mathrm{abr} / 11$ & 325 & 30.481 & $1,07 \%$ \\
\hline $\mathrm{mai} / 11$ & 305 & 37.317 & $0,82 \%$ \\
\hline jun/11 & 301 & 31.960 & $0,94 \%$ \\
\hline jul/11 & 261 & 28.075 & $0,93 \%$ \\
\hline ago/11 & 450 & 35.807 & $1,26 \%$ \\
\hline set/11 & 277 & 31.848 & $0,87 \%$ \\
\hline out/11 & 243 & 30.031 & $0,81 \%$ \\
\hline nov/11 & 248 & 24.415 & $1,02 \%$ \\
\hline $\operatorname{dez} / 11$ & 230 & 37.309 & $0,62 \%$ \\
\hline $\mathrm{jan} / 12$ & 150 & 26.554 & $0,56 \%$ \\
\hline $\mathrm{fev} / 12$ & 208 & 24.013 & $0,87 \%$ \\
\hline $\mathrm{mar} / 12$ & 256 & 38.565 & $0,66 \%$ \\
\hline $\mathrm{abr} / 12$ & 299 & 31.882 & $0,94 \%$ \\
\hline $\mathrm{mai} / 12$ & 311 & 34.063 & $0,91 \%$ \\
\hline jun/12 & 288 & 30.108 & $0,96 \%$ \\
\hline jul/12 & 263 & 28.852 & $0,91 \%$ \\
\hline ago/12 & 415 & 33.223 & $1,25 \%$ \\
\hline set/12 & 241 & 30.888 & $0,78 \%$ \\
\hline out $/ 12$ & 325 & 34.827 & $0,93 \%$ \\
\hline nov/12 & 338 & 33.421 & $1,01 \%$ \\
\hline dez/12 & 343 & 7.615 & \\
\hline jan/13 & 215 & 28.514 & $0,75 \%$ \\
\hline $\mathrm{fev} / 13$ & 208 & 32.507 & $0,64 \%$ \\
\hline $\mathrm{mar} / 13$ & 222 & 37.610 & $0,59 \%$ \\
\hline $\mathrm{abr} / 13$ & 279 & 39.175 & $0,71 \%$ \\
\hline $\mathrm{mai} / 13$ & 299 & 36.551 & $0,82 \%$ \\
\hline jun/13 & 164 & 16.056 & $1,02 \%$ \\
\hline jul/13 & 161 & 26.494 & $0,61 \%$ \\
\hline ago/13 & & 35.484 & \\
\hline set/13 & & 33.535 & \\
\hline out $/ 13$ & & 33.658 & \\
\hline nov $/ 13$ & 52 & 32.148 & \\
\hline $\mathrm{dez} / 13$ & 306 & 25.766 & $1,19 \%$ \\
\hline
\end{tabular}

Fonte: Dados trabalhados pelo autor com informações do Sig-Detran/DF. 
Da série histórica construída obteve-se a média mensal do índice de infrações aplicadas para cada equipamento. Os dados foram dispostos em ordem decrescente, conforme apresenta a Tabela 4.3.

Tabela 4.3: Equipamentos de ASV em ordem decrescente de índice médio mensal de infrações, de janeiro/2009 a dezembro/2013

\begin{tabular}{|c|c|c|c|c|c|}
\hline Equipamento & Índice & Equipamento & Índice & Equipamento & Índice \\
\hline ASV121 & $0,81 \%$ & ASV120 & $0,08 \%$ & ASV017 & $0,04 \%$ \\
\hline ASV080 & $0,42 \%$ & ASV042 & $0,08 \%$ & ASV147 & $0,04 \%$ \\
\hline ASV117 & $0,38 \%$ & ASV072 & $0,08 \%$ & ASV089 & $0,04 \%$ \\
\hline ASV122 & $0,35 \%$ & ASV067 & $0,08 \%$ & ASV066 & $0,04 \%$ \\
\hline ASV013 & $0,31 \%$ & ASV026 & $0,08 \%$ & ASV099 & $0,04 \%$ \\
\hline ASV056 & $0,30 \%$ & ASV130 & $0,08 \%$ & ASV050 & $0,04 \%$ \\
\hline ASV143 & $0,29 \%$ & ASV008 & $0,08 \%$ & ASV139 & $0,04 \%$ \\
\hline ASV078 & $0,26 \%$ & ASV025 & $0,07 \%$ & ASV058 & $0,04 \%$ \\
\hline ASV055 & $0,25 \%$ & ASV048 & $0,07 \%$ & ASV036 & $0,04 \%$ \\
\hline ASV046 & $0,25 \%$ & ASV097 & $0,07 \%$ & ASV098 & $0,04 \%$ \\
\hline ASV135 & $0,23 \%$ & ASV030 & $0,07 \%$ & ASV051 & $0,04 \%$ \\
\hline ASV045 & $0,23 \%$ & ASV014 & $0,07 \%$ & ASV016 & $0,04 \%$ \\
\hline ASV065 & $0,21 \%$ & ASV047 & $0,07 \%$ & ASV037 & $0,04 \%$ \\
\hline ASV021 & $0,17 \%$ & ASV093 & $0,07 \%$ & ASV010 & $0,04 \%$ \\
\hline ASV144 & $0,15 \%$ & ASV053 & $0,07 \%$ & ASV124 & $0,04 \%$ \\
\hline ASV136 & $0,15 \%$ & ASV062 & $0,06 \%$ & ASV105 & $0,04 \%$ \\
\hline ASV133 & $0,14 \%$ & ASV091 & $0,06 \%$ & ASV052 & $0,03 \%$ \\
\hline ASV079 & $0,14 \%$ & ASV113 & $0,06 \%$ & ASV109 & $0,03 \%$ \\
\hline ASV004 & $0,14 \%$ & ASV090 & $0,06 \%$ & ASV059 & $0,03 \%$ \\
\hline ASV141 & $0,14 \%$ & ASV054 & $0,06 \%$ & ASV034 & $0,03 \%$ \\
\hline ASV115 & $0,14 \%$ & ASV028 & $0,06 \%$ & ASV033 & $0,03 \%$ \\
\hline ASV071 & $0,13 \%$ & ASV063 & $0,06 \%$ & ASV018 & $0,03 \%$ \\
\hline ASV146 & $0,13 \%$ & ASV060 & $0,06 \%$ & ASV076 & $0,03 \%$ \\
\hline ASV027 & $0,13 \%$ & ASV040 & $0,06 \%$ & ASV128 & $0,03 \%$ \\
\hline ASV151 & $0,12 \%$ & ASV039 & $0,06 \%$ & ASV140 & $0,03 \%$ \\
\hline ASV138 & $0,11 \%$ & ASV073 & $0,06 \%$ & ASV020 & $0,03 \%$ \\
\hline ASV001 & $0,11 \%$ & ASV007 & $0,05 \%$ & ASV077 & $0,03 \%$ \\
\hline ASV094 & $0,11 \%$ & ASV043 & $0,05 \%$ & ASV019 & $0,03 \%$ \\
\hline ASV044 & $0,10 \%$ & ASV095 & $0,05 \%$ & ASV038 & $0,03 \%$ \\
\hline ASV002 & $0,10 \%$ & ASV064 & $0,05 \%$ & ASV148 & $0,03 \%$ \\
\hline ASV015 & $0,10 \%$ & ASV035 & $0,05 \%$ & ASV061 & $0,03 \%$ \\
\hline ASV118 & $0,09 \%$ & ASV149 & $0,05 \%$ & ASV102 & $0,02 \%$ \\
\hline ASV123 & $0,09 \%$ & ASV081 & $0,05 \%$ & ASV012 & $0,02 \%$ \\
\hline ASV103 & $0,09 \%$ & ASV041 & $0,05 \%$ & ASV142 & $0,01 \%$ \\
\hline ASV029 & $0,09 \%$ & ASV110 & $0,05 \%$ & ASV009 & $0,01 \%$ \\
\hline ASV005 & $0,08 \%$ & ASV137 & $0,05 \%$ & ASV032 & $0,01 \%$ \\
\hline ASV112 & $0,08 \%$ & ASV031 & $0,05 \%$ & ASV096 & $0,01 \%$ \\
\hline ASV003 & $0,08 \%$ & ASV024 & $0,05 \%$ & ASV129 & $0,01 \%$ \\
\hline ASV092 & $0,08 \%$ & ASV088 & $0,05 \%$ & ASV132 & $0,01 \%$ \\
\hline ASV145 & $0,08 \%$ & ASV125 & $0,05 \%$ & ASV131 & $0,01 \%$ \\
\hline ASV057 & $0,08 \%$ & ASV011 & $0,05 \%$ & ASV069 & $0,01 \%$ \\
\hline
\end{tabular}

Fonte: Dados trabalhados pelo autor com informações do Sig-Detran/DF. 
A partir do uso da ferramenta box plot para analisar as informações extraídas do conjunto de equipamentos, foram identificados os limites apresentados na Tabela 4.4.

Tabela 4.4: Resumo das medidas estatísticas e valores obtidos com a ferramenta box plot, de janeiro/2009 a dezembro/2013

\begin{tabular}{c|c}
\hline \multicolumn{2}{c}{ Índice de infrações - box plot } \\
\hline $\mathrm{N}^{\mathbf{o}}$ equipamentos & 123 \\
\hline Média & $0,09 \%$ \\
\hline Mediana & $0,06 \%$ \\
\hline Intervalo & $0,80 \%$ \\
\hline Mínimo & $0,01 \%$ \\
\hline Máximo & $0,81 \%$ \\
\hline $1^{\circ}$ Quartil & $0,04 \%$ \\
\hline $3^{\circ}$ Quartil & $0,09 \%$ \\
\hline DIQ & $0,06 \%$ \\
\hline 1,5 x DIQ & $0,09 \%$ \\
\hline Limite superior & $0,18 \%$ \\
\hline Limite inferior & $0,00 \%$ \\
\hline Pontos extremos & $0,27 \%$ \\
\hline
\end{tabular}

Fonte: Dados trabalhados pelo autor com informações do Sig-Detran/DF.

É interessante observar que a média do índice de infrações, considerando-se todos os 123 equipamentos, é de nove infrações aplicadas para cada dez mil veículos. O equipamento com maior índice (ASV 121) apresentou 81 infrações aplicadas para cada dez mil veículos. A mediana de seis infrações aplicadas para cada dez mil veículos é menor do que a média, que é influenciada por um pequeno grupo de equipamentos, foco de investigação deste estudo.

Como citado anteriormente, o Sig-Detran/DF detém o histórico de infrações dos equipamentos não metrológicos de fiscalização eletrônica, porém essas infrações não estão divididas por tipo (ASV, PSF e VAL); apresenta-se somente o total. Assim, o índice de infrações obtido envolve todos os tipos de infrações (ASV, PSF e VAL).

Com base no que foi explanado sobre o uso da ferramenta box plot, os equipamentos que apresentaram índice de infrações aplicadas acima do limite superior foram selecionados para estudo, sendo classificados como outliers (entre o limite superior e Q3 + 3,0 DIQ) e pontos extremos (acima de Q3 + 3,0 DIQ), conforme mostra a Tabela 4.5. 
Tabela 4.5: Equipamentos considerados como pontos extremos e outliers, de janeiro/2009 a dezembro/2013

\begin{tabular}{c|c|c}
\hline Equipamento & Índice de infrações & Classificação \\
\hline ASV 121 & $0,81 \%$ & \multirow{2}{*}{ Pontos extremos } \\
\cline { 1 - 2 } ASV 080 & $0,42 \%$ & \\
\hline ASV 117 & $0,38 \%$ & \\
\hline ASV 122 & $0,35 \%$ & \\
\hline ASV 013 & $0,31 \%$ & \\
\hline ASV 056 & $0,30 \%$ & \multirow{2}{*}{ Outliers (ou pontos } \\
\hline ASV 143 & $0,29 \%$ & \multirow{2}{*}{ discrepantes) } \\
\hline ASV 078 & $0,26 \%$ & \\
\hline ASV 055 & $0,25 \%$ & \\
\hline ASV 046 & $0,25 \%$ & \\
\hline ASV 135 & $0,23 \%$ & \\
\hline ASV 045 & $0,23 \%$ & \\
\hline ASV 065 & $0,21 \%$ & \\
\hline
\end{tabular}

Fonte: Dados trabalhados pelo autor com informações do Sig-Detran/DF.

De forma a identificar as interseções com problemas que concernem especificamente ao ASV, foi solicitado à empresa prestadora do serviço um relatório estatístico sobre os equipamentos identificados pela ferramenta estatística box plot. Esse relatório também forneceu subsídios para as visitas in loco desta pesquisa.

\subsubsection{Seleção das interseções do estudo com base em relatório estatístico}

O relatório estatístico solicitado à empresa prestadora do serviço corresponde ao período de abril de 2013 a março de 2014 e não está disponível no Sig-Detran/DF. As informações solicitadas correspondem aos objetivos da presente pesquisa e foram selecionadas pelo autor.

O relatório estatístico norteia as ações de investigação propostas por este trabalho, auxiliando na identificação dos fatores que afetam a eficácia dos EFEs com base no índice de infrações aplicadas.

Refinando os locais de pesquisa identificados pela ferramenta box plot, a Tabela 4.6 apresenta os tipos de infrações para cada um dos equipamentos. Foram selecionadas somente as interseções com problemas de ASV, quais sejam, aquelas em que estão instalados os equipamentos ASV 121, ASV 080, ASV 122, ASV 143 e ASV 045. 
Tabela 4.6: Percentual de infrações por tipo, de abril/2013 a março/2014

\begin{tabular}{c|c|c|c|c}
\hline \multirow{2}{*}{ Equipamento } & \multirow{2}{*}{$\begin{array}{l}\text { Indice de } \\
\text { infrações }\end{array}$} & \multicolumn{3}{|c}{ Percentual de infrações por tipo } \\
\cline { 3 - 5 } & $0,81 \%$ & $100 \%$ & PSF & VAL \\
\hline ASV 121 & $0,42 \%$ & $100 \%$ & - & $0 \%$ \\
\hline ASV 080 & $0,38 \%$ & $63 \%$ & $37 \%$ & $0 \%$ \\
\hline ASV 117 & $0,35 \%$ & $100 \%$ & - & $0 \%$ \\
\hline ASV 122 & $0,31 \%$ & $50 \%$ & $6 \%$ & $44 \%$ \\
\hline ASV 013 & $0,30 \%$ & $6 \%$ & - & $94 \%$ \\
\hline ASV 056 & $0,29 \%$ & $100 \%$ & - & $0 \%$ \\
\hline ASV 143 & $0,26 \%$ & $15 \%$ & $5 \%$ & $80 \%$ \\
\hline ASV 078 & $0,25 \%$ & $33 \%$ & $7 \%$ & $60 \%$ \\
\hline ASV 055 & $0,25 \%$ & $5 \%$ & $1 \%$ & $94 \%$ \\
\hline ASV 046 & $0,23 \%$ & $58 \%$ & $41 \%$ & $1 \%$ \\
\hline ASV 135 & $0,23 \%$ & $100 \%$ & - & $0 \%$ \\
\hline ASV 045 & $0,21 \%$ & $26 \%$ & - & $74 \%$ \\
\hline ASV 065 & & & - & \\
\hline
\end{tabular}

Fonte: Relatório estatístico fornecido pela empresa prestadora do serviço.

Nota: (-) significa que não há faixa de pedestre no local.

De forma a subsidiar as visitas em campo, o relatório estatístico propiciou outras informações, como hora-pico de infrações, percentual de infrações por faixa de trânsito, percentual de veículos e percentual de infrações por tipo de veículo (motocicleta, automóvel, ônibus/caminhão). A Tabela 4.7 apresenta as informações para os equipamentos selecionados.

Tabela 4.7: Características das infrações, de abril/2013 a março/2014

\begin{tabular}{c|c|c|c|c|c|c|c|c|c}
\hline & \multirow{2}{*}{ Equipamento } & \multirow{2}{*}{$\begin{array}{c}\text { Hora-pico } \\
\text { Infrações }\end{array}$} & \multicolumn{2}{|c|}{$\begin{array}{c}\text { Infrações por } \\
\text { Faixa de Trânsito* }\end{array}$} & \multicolumn{3}{|c|}{ Infração por Tipo Veículo } & \multicolumn{3}{c}{ Fluxo por Tipo Veículo } \\
\cline { 5 - 10 } & & $\mathbf{1}$ & $\mathbf{2}$ & Motocicleta & Automóvel & $\begin{array}{c}\text { Ônibus / } \\
\text { Caminhão }\end{array}$ & Motocicleta & Automóvel & $\begin{array}{c}\text { Ônibus / } \\
\text { Caminhão }\end{array}$ \\
\hline ASV 121 & $15 \mathrm{~h}$ & $73 \%$ & $27 \%$ & $4,6 \%$ & $93,5 \%$ & $1,9 \%$ & $0,100 \%$ & $97,500 \%$ & $2,400 \%$ \\
ASV 080 & $15 \mathrm{~h}$ & $35 \%$ & $65 \%$ & $1,3 \%$ & $92,6 \%$ & $6,1 \%$ & $0,003 \%$ & $85,882 \%$ & $14,115 \%$ \\
ASV 122 & $14 \mathrm{~h}$ & $18 \%$ & $82 \%$ & $1,9 \%$ & $94,5 \%$ & $3,6 \%$ & $0,009 \%$ & $98,821 \%$ & $1,170 \%$ \\
ASV 143 & $7 \mathrm{~h}$ & - & - & $6,3 \%$ & $89,7 \%$ & $4,0 \%$ & $0,002 \%$ & $98,912 \%$ & $1,086 \%$ \\
ASV 045 & $17 \mathrm{~h}$ & $78 \%$ & $22 \%$ & $1,2 \%$ & $91,5 \%$ & $7,3 \%$ & $0,001 \%$ & $94,984 \%$ & $5,015 \%$ \\
\hline
\end{tabular}

Fonte: Relatório estatístico fornecido pela empresa prestadora do serviço.

*O percentual de infrações por faixa de trânsito refere-se ao período de dezembro/2012 a março/2013. Nesse período, para o equipamento ASV 143, uma das faixas estava com o laço rompido, o que prejudicou a análise. A faixa 1 corresponde à faixa da esquerda no sentido da via. 
As visitas in loco foram realizadas conforme a hora-pico de infrações indicada na Tabela 4.7. Observa-se que somente os equipamentos ASV 143 e ASV 045 tiveram a hora-pico de infrações correspondente ao horário comercial.

O percentual de infração por faixa de trânsito subsidiou a investigação da ocorrência de infrações relacionadas à geometria da via. Dos cinco pontos estudados, três estão em trecho curvo (ASV 121, ASV 143 e ASV 045) e dois precedem conversão à direita (ASV 080 e ASV 122). Em todos os equipamentos a faixa interna à curva apresenta maior percentual de infrações. Entende-se que esse número também é influenciado pelos períodos de baixo movimento, quando condutores buscam fazer a curva percorrendo o raio interno.

Observa-se também que em todos os locais estudados o tempo de retardo foi avaliado, dado que a metodologia descrita no tópico 3.6 verifica a influência de trecho curvo na determinação do tempo mínimo de retardo, nos termos da Portaria Denatran $n^{\circ}$ 16/2014 (DENATRAN, 2014).

A comparação entre o fluxo e o percentual de infrações por tipo de veículo é prejudicada pela tecnologia de laços indutivos empregada nos equipamentos. As motocicletas transitam entre as faixas para não ser identificadas, principalmente quando a conduta praticada é de violação às leis de trânsito. Essas informações podem ser úteis também para ações educativas nos casos em que um determinado perfil de condutor em uma dada interseção for identificado.

Com relação aos veículos pesados os equipamentos ASV 122, ASV 143 e ASV 045 apresentam percentual de infrações maior que o percentual do fluxo correspondente a esses veículos, onde há linhas de ônibus passando pelo equipamento ASV 143. O equipamento ASV 080 também está localizado em via com passagem de linha de ônibus, porém esses veículos não realizam movimento de conversão. Conforme Bonneson, Zimmerman e Brewer (2002), um condutor de veículo pesado é duas vezes mais propenso a avançar a indicação de vermelho que um condutor de automóvel. 


\subsubsection{Autos de infração}

De forma a demonstrar a importância de informações geradas pelos autos de infração, foram solicitados cem autos de infração aleatórios de cada uma das interseções em análise. Observou-se o tempo de cometimento da infração após o início do vermelho, a presença de congestionamento a jusante e, para os equipamentos ASV 121 e ASV 080, se o veículo estava posicionado em movimento de conversão. A Tabela 4.8 apresenta os dados de tempo de passagem após o vermelho e a situação de fluxo a jusante para cada uma das interseções estudadas.

Tabela 4.8: Tempo de passagem do veículo após o início do vermelho, fluxo a jusante e movimentos de conversão

\begin{tabular}{c|c|c|c|c|c}
\hline & ASV 121 & ASV 080 & ASV 122 & ASV 143 & ASV 045 \\
\hline 1 s a 2 s & 54 & 47 & 63 & 53 & 33 \\
\hline 2 s a 3 s & 23 & 17 & 18 & 21 & 28 \\
\hline 3 s a 5 s & 6 & 15 & 8 & 8 & 12 \\
\hline 5 s a 10 s & 1 & 6 & 4 & 6 & 4 \\
\hline Acima de 10 s & 16 & 15 & 7 & 12 & 23 \\
\hline Fluxo livre (\%) & 92 & 59 & 74 & 56 & 76 \\
\hline Congestionamento (\%) & 8 & 41 & 26 & 44 & 24 \\
\hline Em conversão (\%) & 6 & 59 & - & - & - \\
\hline
\end{tabular}

Fonte: Elaborado pelo autor, 2014.

O movimento de conversão é opcional somente para a interseção onde está localizado o equipamento ASV 080 (conversão à direita). No caso da interseção onde está o equipamento ASV 121, a conversão à esquerda é proibida, e, ainda assim, foram observados $6 \%$ dos veículos cometendo essa infração, juntamente com o ASV.

Além da análise entre os tempos de retardo calculado e adotado, que será realizada no Capítulo 5, apresenta-se interessante a informação do percentual de veículos acima de $10 \mathrm{~s}$, totalizando até $23 \%$ para o equipamento ASV 045, mesmo com sua ostensividade. A Figura 4.2, extraída de um auto de infração com tempo de $36 \mathrm{~s}$ após o início do vermelho, retrata um exemplo de veículo que avança o sinal mais de $10 \mathrm{~s}$ após o início da indicação vermelha. 
INFORMAÇÕES DA INFRAÇÃO

Número do Auto:

Infraçăo cometida: 605-0 AVANÇAR O SINAL VERMELHO DO SEMAFORO

Placa:

Modelo: FIAT/FIORINO IE

Tempo regulam.: $\quad 1,0 \mathrm{~s}$

Tempo medido : $\quad 36 \mathrm{~s}$

Data/hora: $\quad 21 / 12 / 201309: 43$

Local da infração: VIA ERSW ALT GALERIA DOS ESTADOS SENT SCS/SBS

SEMAFORO CRUZ 016

Faixa/Pista: 1

Instrumento: Dpi42-D RIS045

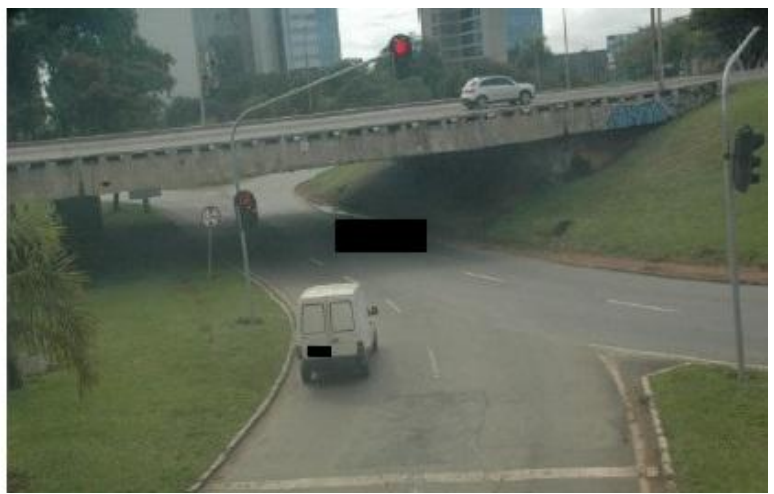

Figura 4.2: Veículo avançando o sinal após $36 \mathrm{~s}$ da indicação vermelha do semáforo

Deve-se lembrar que, de acordo com as referências pesquisadas, a desconsideração do vermelho é mais bem tratada com contramedidas de fiscalização (BONNESON, ZIMMERMAN e BREWER, 2002), as quais devem estar assentadas nos princípios básicos da certeza, rapidez e severidade da punição (GIBBS, 1979 apud CARNIS e BLAIS, 2013). 


\section{RESULTADOS E DISCUSSÃO}

\subsection{VISITAS TÉCNICAS}

Foram realizadas visitas técnicas em dias úteis típicos e em horários-pico de infrações nas interseções onde estão localizados os equipamentos ASV 121, ASV 080, ASV 122, ASV 143 e ASV 045, de modo a identificar os fatores observados no referencial teórico. Foram feitas fotografias das aproximações em cada um dos cruzamentos e a aproximação fiscalizada foi filmada por no mínimo vinte minutos. Os tempos semafóricos foram cronometrados em campo e conferidos com as filmagens. De modo complementar, imagens de satélite foram utilizadas para uma melhor visualização dos cruzamentos.

Como citado anteriormente, a faixa de trânsito com maior percentual de infrações obtida por relatório estatístico foi observada em campo, assim como o fluxo por tipo de veículo. Procurou-se identificar visualmente a correspondência entre os dados trabalhados e a observação em campo. A presença de linhas de ônibus foi assinalada.

Aspectos geométricos e de sinalização foram medidos in loco, sendo observados os parâmetros necessários para o cálculo de entreverdes conforme o manual Sinalização semafórica (CONTRAN, 2014). Para o cálculo do tempo de retardo, foi seguido o método proposto por Filizola, Pelisson e Silva (2014) em atendimento à Portaria Denatran no 16/2004 (DENATRAN, 2004).

A padronização da coleta de informações baseou-se em formulário de inspeção de campo adaptado de Hallmark, Oneyear e McDonald (2012), apresentado no Apêndice D.

\subsection{INTERSEÇÕES ESTUDADAS}

\subsubsection{ASV 121}

Em uma interseção com duas faixas de trânsito de 3,25 m cada, em aclive e aproximação em curva horizontal, este equipamento apresentou o maior índice de infrações, 81 a cada dez mil veículos. Foi quase o dobro do segundo equipamento com maior índice, o ASV 080, com 42 infrações a cada dez mil veículos. A largura do cruzamento é de 10,5 m (três faixas de trânsito). 
O grupo de movimento da aproximação fiscalizada pelo equipamento ASV 121 (MV1) é o mesmo da aproximação fiscalizada pelo equipamento ASV 122 (MV2), motivo pelo qual é proibida a conversão à esquerda (Figura 5.1).

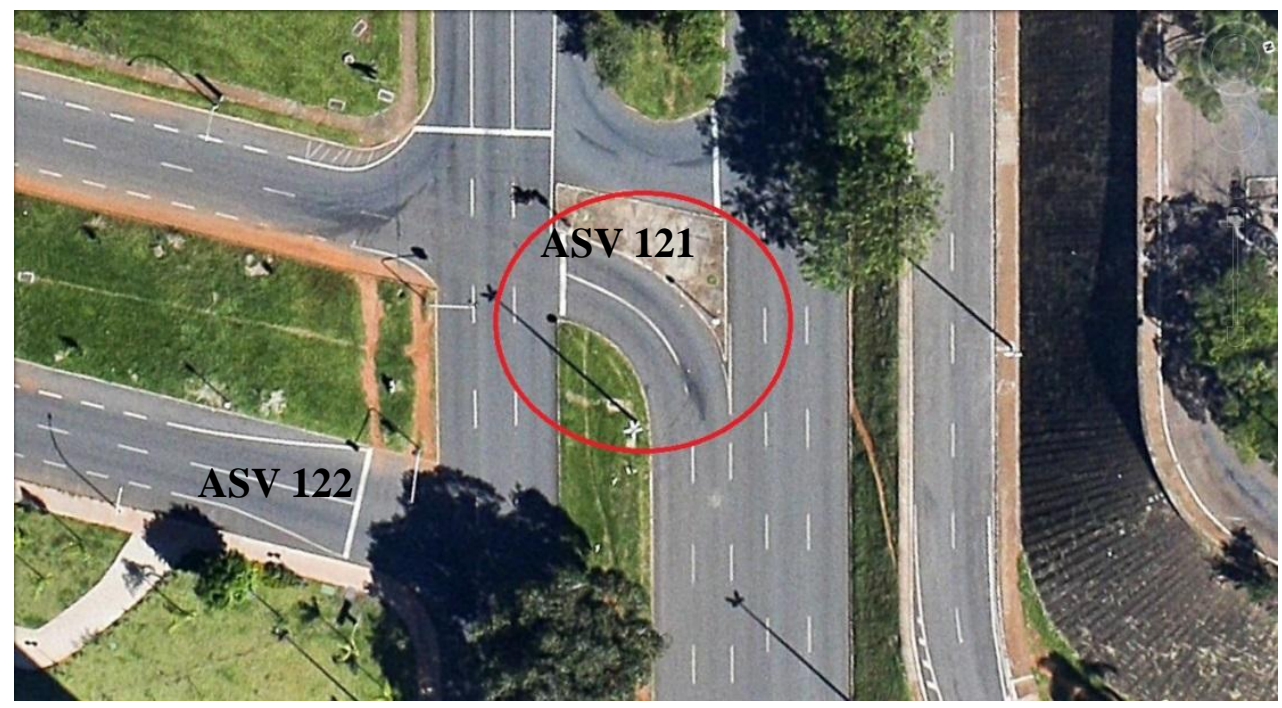

Figura 5.1: Imagem de satélite da aproximação ASV 121

A Figura 5.2 mostra dois focos semafóricos: um foco antes da interseção, instalado em coluna (ao lado da linha de retenção), e outro após a interseção em braço projetado (utilizado em conjunto com um foco semafórico de outra aproximação), em ângulo de visão desfavorável para quem faz a conversão. O foco semafórico apresenta anteparo, pestana e luz LED com tamanho de $30 \mathrm{~cm}$ para o vermelho. Além da sinalização semafórica, há a sinalização de regulamentação "Proibido virar à esquerda" (R-4a).

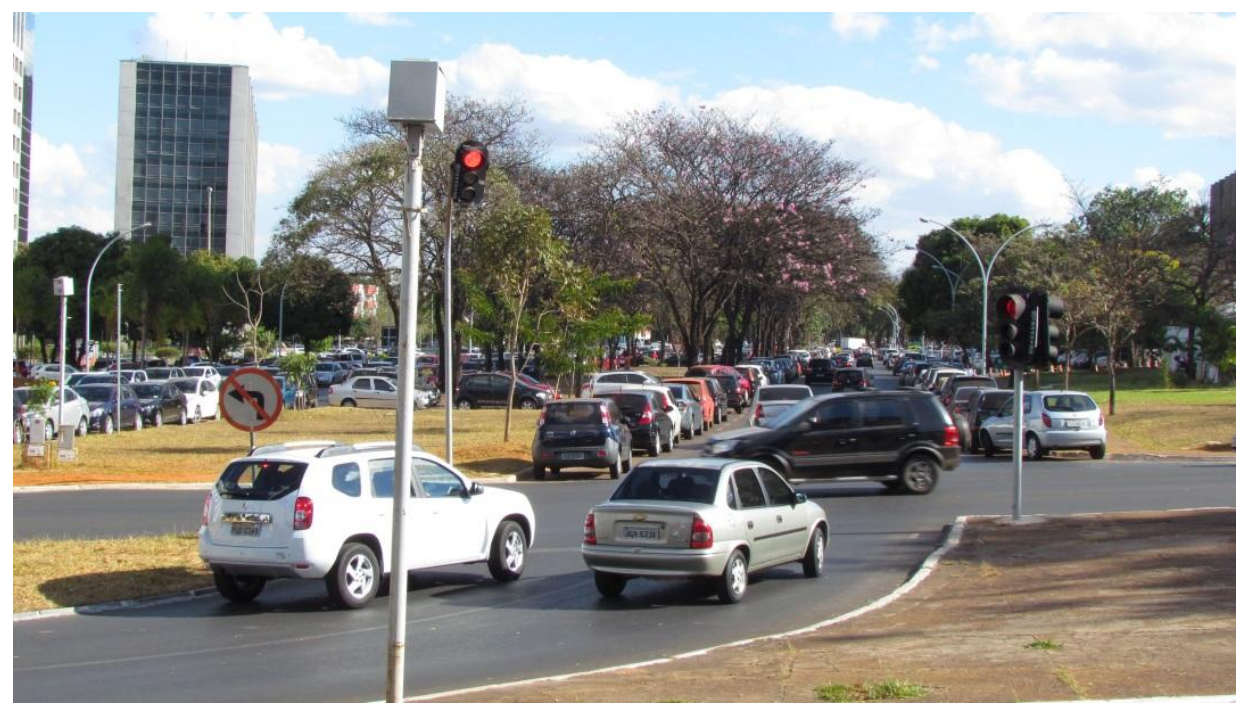

Figura 5.2: Vista da aproximação do equipamento ASV 121

Foto: O autor, 2014. 
Conforme pode ser visualizado na Figura 5.3, foram observados veículos estacionados na faixa esquerda da via de aproximação, próximo ao canteiro central. A aproximação possui, a montante, via com velocidade regulamentada de $60 \mathrm{~km} / \mathrm{h}$ e, a jusante, via com velocidade regulamentada de $50 \mathrm{~km} / \mathrm{h}$.

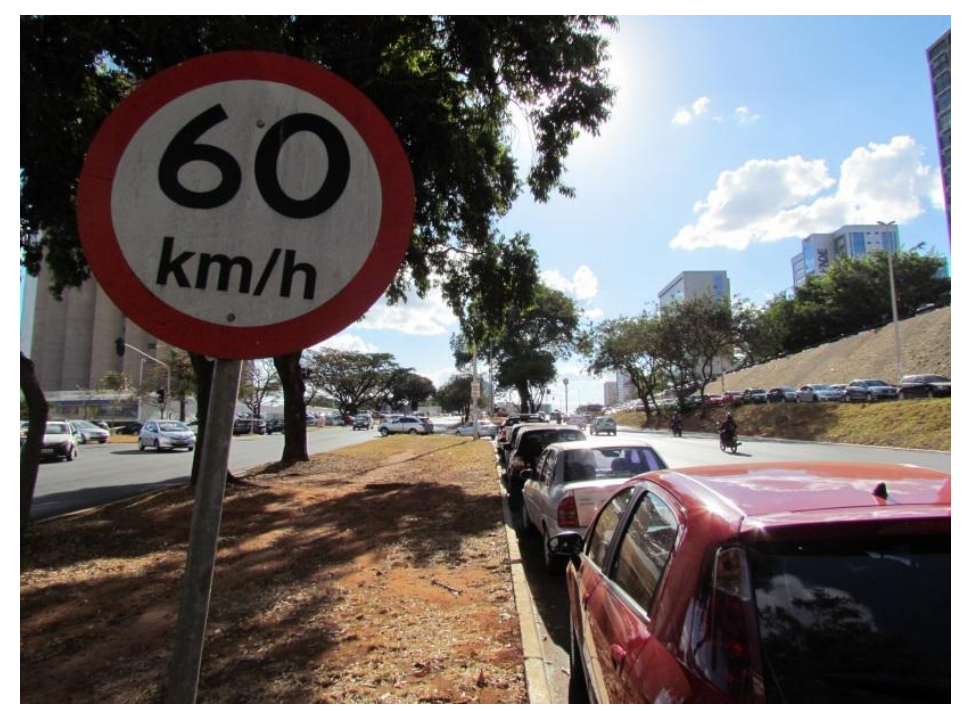

Figura 5.3: Veículos estacionados em faixa de trânsito ao longo da via

Foto: O autor, 2014.

A programação semafórica da aproximação é de $20 \mathrm{~s}$ de verde, $3 \mathrm{~s}$ de amarelo e $45 \mathrm{~s}$ de vermelho. O tempo de vermelho geral do cruzamento é de $2 \mathrm{~s}$ e o tempo total do ciclo, de 68 s, com dois estágios. Observou-se que os veículos chegam em pelotão e que, em alguns ciclos, a capacidade de atendimento não é suficiente para que todos os veículos cruzem a interseção. Há predomínio de automóveis e não há linhas de ônibus no local. Foram observados caminhões de pequeno porte.

Após a interseção há faixa de travessia de pedestres não semaforizada que causa retenção do fluxo de veículos, além de um retorno de acesso a via, e podem impactar o fluxo de veículos na indicação verde do semáforo. Este fator aliado ao tempo de $20 \mathrm{~s}$ de verde e a hora-pico de veículos representam atraso na interseção e pode influenciar o comportamento do condutor em avançar a indicação vermelha do semáforo.

Com relação à fiscalização eletrônica, somente por imagem captada pelo Google Street View (Figura 5.4) foi possível identificar o posicionamento dos laços indutivos, uma vez que o pavimento da via foi recentemente recapeado. 


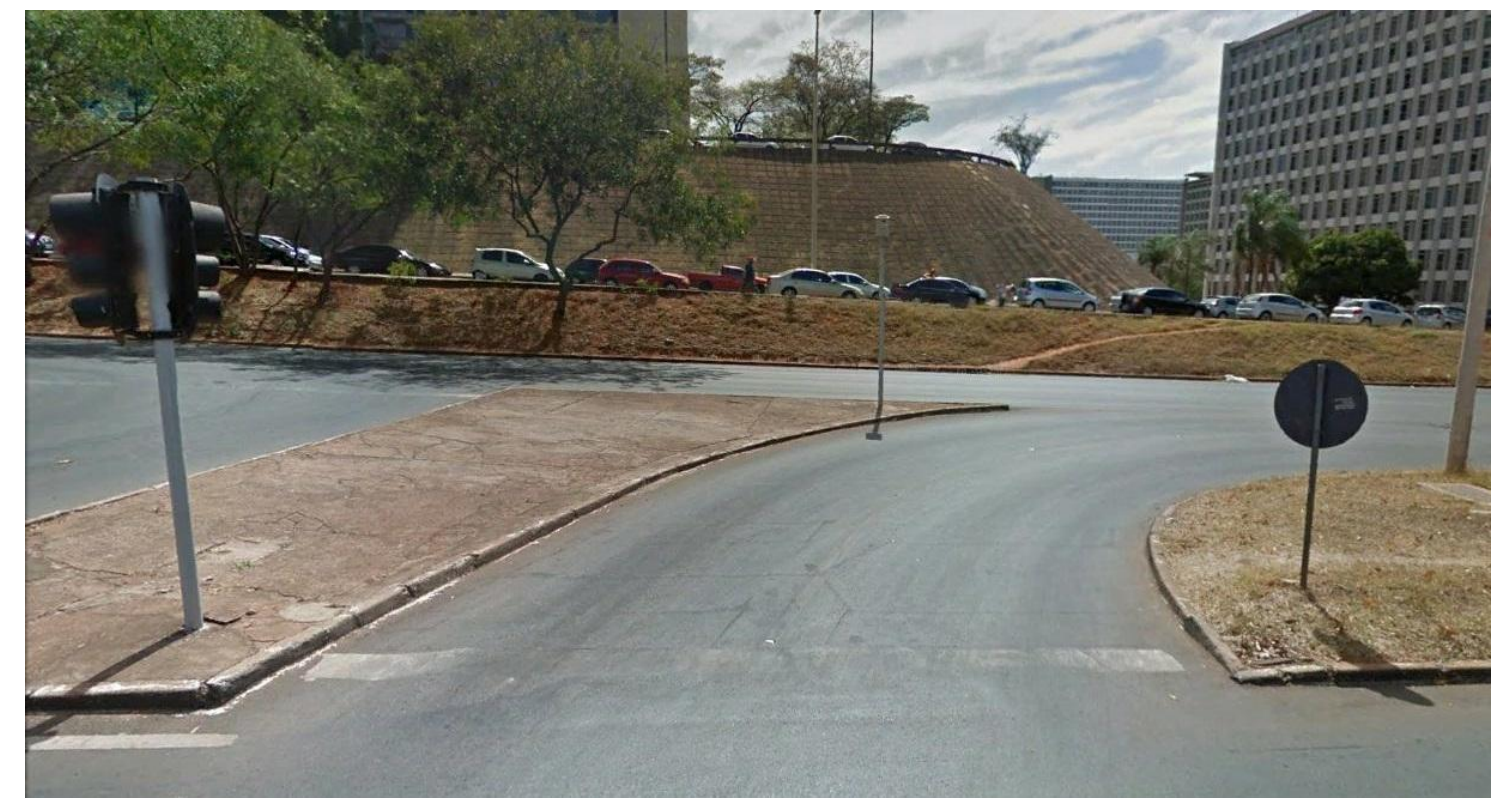

Figura 5.4: Imagem captada pelo Google Street View, que destaca o posicionamento dos laços indutivos do equipamento ASV 121

Entende-se que a colocação equivocada dos laços antes da linha de retenção seja o motivo pelo qual esse equipamento apresente o maior índice de infrações entre todos os 123 equipamentos instalados, em valor praticamente o dobro que o segundo colocado. $\mathrm{O}$ fato do equipamento registrar a imagem do veículo que passa pelo laço, ainda que não avance a faixa de retenção causa o descumprimento da Portaria Denatran $n^{\circ}$ 16/2004. O órgão de trânsito também deve verificar se os dados inseridos no Sig-Detran/DF correspondem à realidade, uma vez que veículos que não cruzam a faixa de retenção não podem ser autuados por avanço de sinal. Como citado anteriormente, os dados utilizados neste trabalho são de janeiro de 2009 a dezembro de 2013 e, neste período, o equipamento ASV 121 apresenta índices elevados de maneira uniforme.

\subsubsection{ASV 080}

A interseção em questão tem duas faixas de trânsito de $3 \mathrm{~m}$ cada, trecho plano e cruzamento em T, onde a aproximação fiscalizada permite o movimento de seguir em frente ou convergir à direita. A via possui duplo sentido de circulação sem canteiro central, com duas faixas de trânsito por sentido e velocidade regulamentada de $60 \mathrm{~km} / \mathrm{h}$. As calçadas e o pavimento da via estão em mau estado de conservação, assim como a sinalização horizontal. Cerca de $70 \mathrm{~m}$ a jusante há cruzamento semaforizado com via arterial. Apesar da distância, os cruzamentos não estão coordenados. Trabalhando em quatro estágios, um dos quais é exclusivo para pedestres, 
a programação semafórica da aproximação é de $1 \mathrm{~min} 34 \mathrm{~s}$ de verde, $3 \mathrm{~s}$ de amarelo e 3 min $12 \mathrm{~s}$ de vermelho. O tempo de vermelho geral do cruzamento é de $2 \mathrm{~s}$ e o tempo total do ciclo é de $4 \min 50 \mathrm{~s}$.
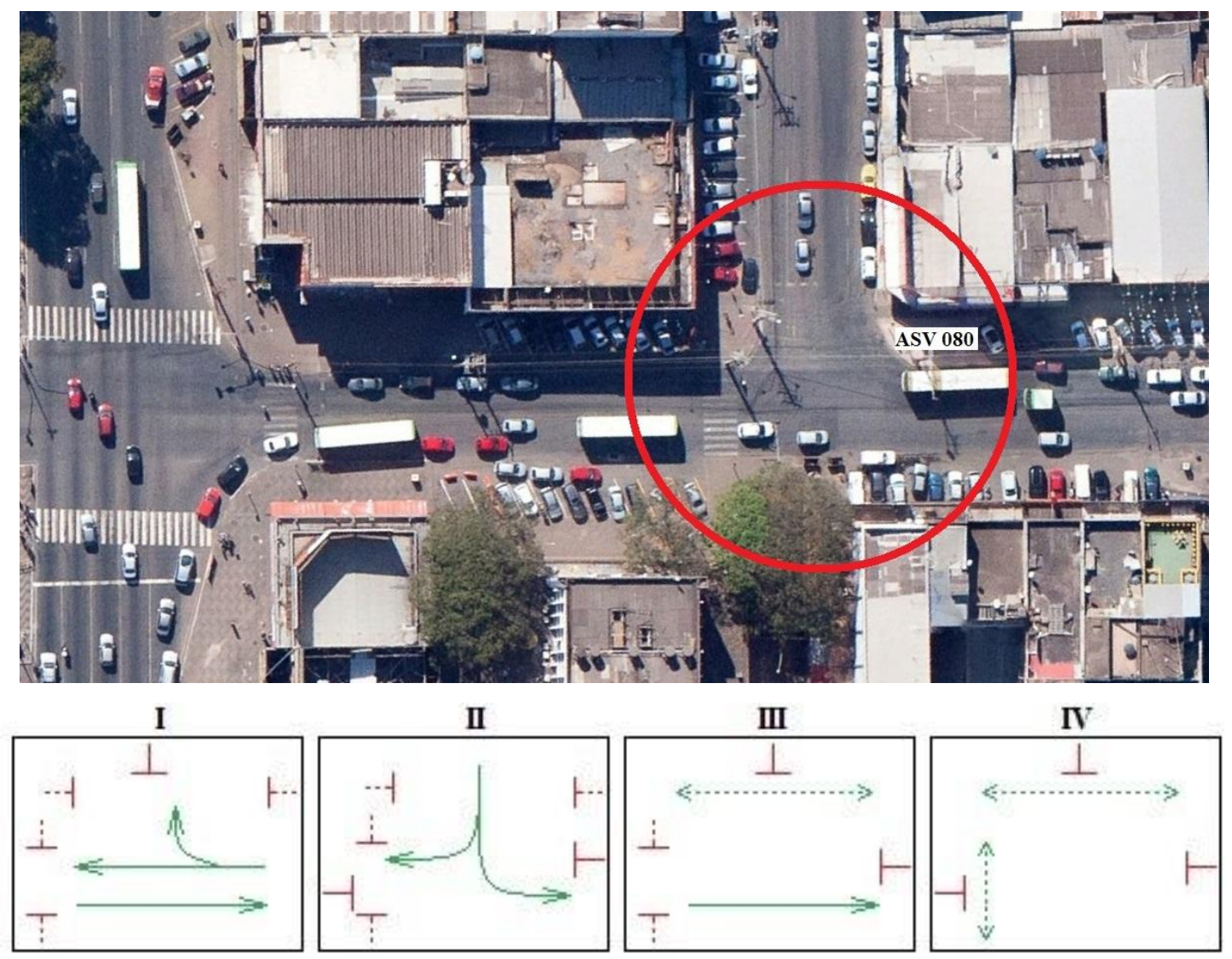

Figura 5.5: Imagem de satélite que retrata a aproximação ASV 080 e diagrama de estágios

A distância da linha de retenção até a esquina é de 9,8 m, havendo mais $15 \mathrm{~m}$ de sinalização horizontal de marcação de área de conflito para que veículos não bloqueiem o cruzamento; após 3,4 m, há faixa de travessia de pedestres semaforizada com $4 \mathrm{~m}$ de largura. Há dois focos semafóricos instalados antes da via transversal em um mesmo suporte, um posicionado na coluna e o outro no braço projetado. Os focos semafóricos apresentam anteparo, pestana e luz LED com tamanho de $30 \mathrm{~cm}$ para indicação vermelha. Como pode ser visualizado na Figura 5.6, a sinalização horizontal de linha de retenção está apagada e a de marcação de área de conflito não segue a normalização vigente (pintura branca em vez de amarela). 


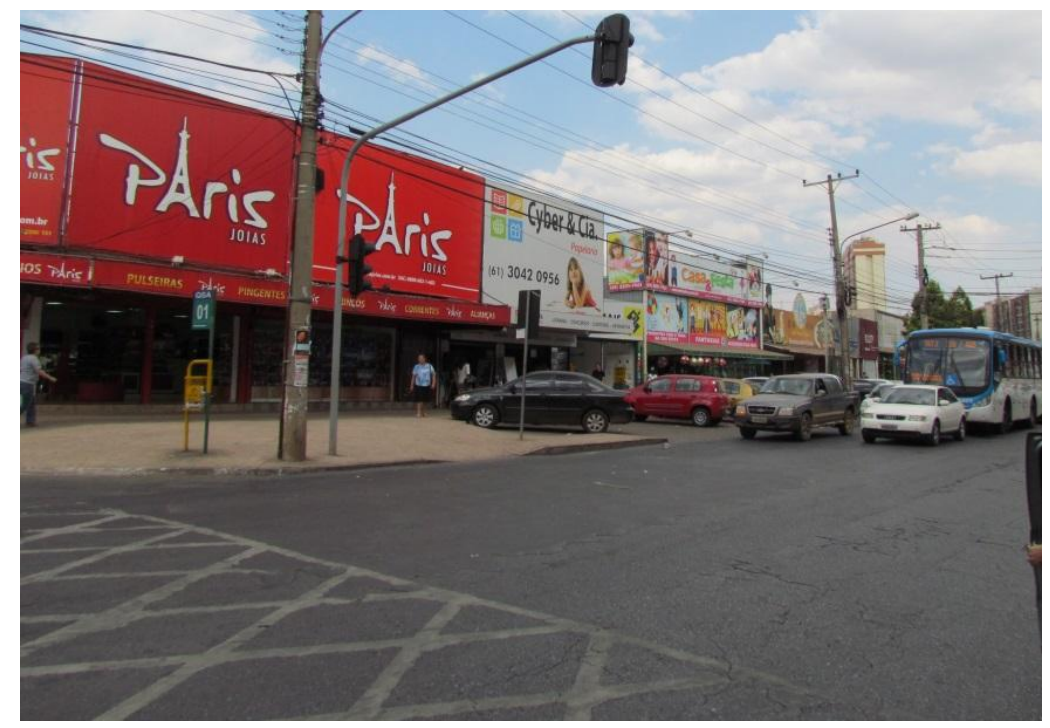

Figura 5.6: Vista para a aproximação fiscalizada pelo equipamento ASV 080

Foto: O autor, 2014.

Há estacionamento a $90^{\circ}$ dos dois lados da via. O fluxo de veículos e de pedestres é intenso, e há linhas de ônibus em ambos os sentidos. Na Figura 5.7 é possível ver o equipamento de fiscalização e, ao fundo, triângulo de segurança em razão de colisão entre um ônibus e um automóvel que saía do estacionamento em marcha a ré.

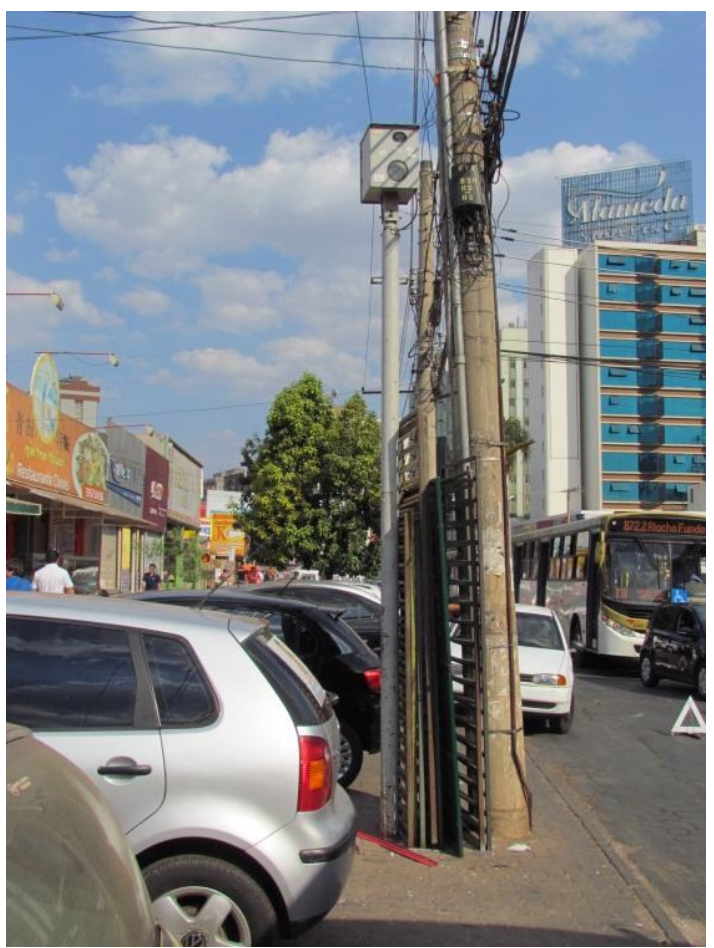

Figura 5.7: Equipamento ASV 080

Foto: O autor, 2014. 
A programação trabalha em rede com semáforo $70 \mathrm{~m}$ a jusante, porém o início do verde da aproximação estudada é impactado pela grande quantidade de veículos parados na caixa de retenção, como mostra a Figura 5.8. A defasagem entre a interseção estudada e a interseção a jusante é de $40 \mathrm{~s}$.

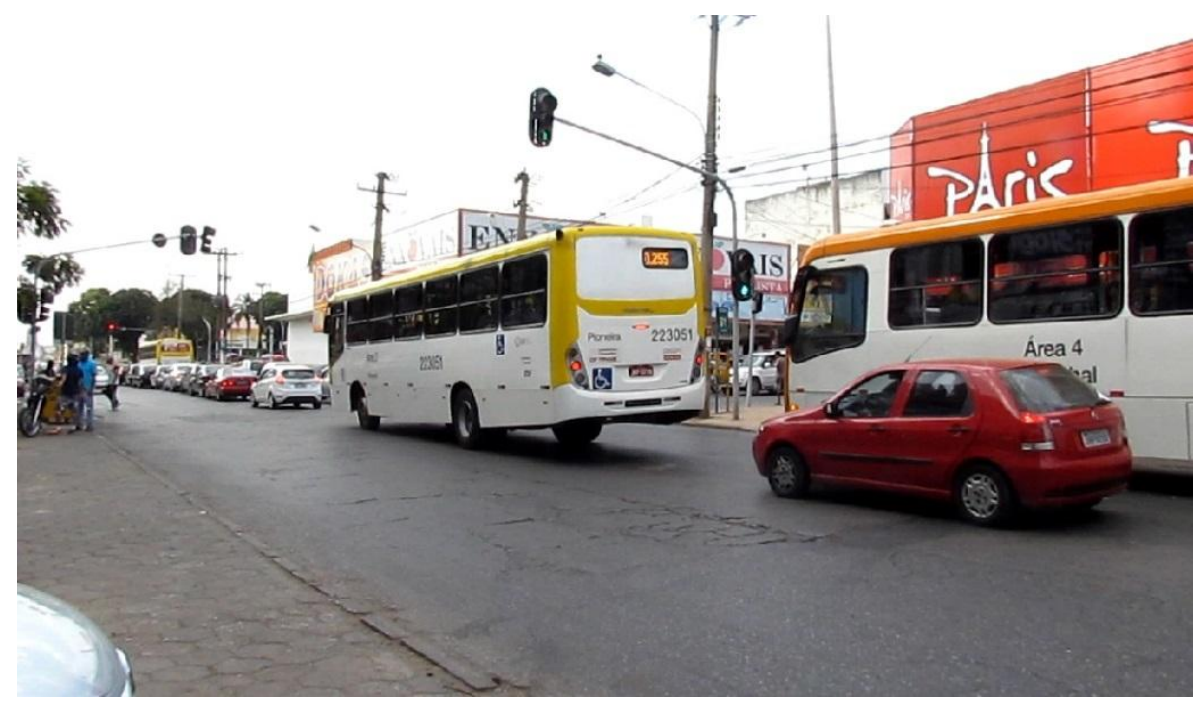

Figura 5.8: Vista da aproximação fiscalizada pelo equipamento ASV 080

Foto: O autor, 2014.

\subsubsection{ASV 122}

A interseção tem duas faixas de trânsito de largura variando de 3,15 m (limite da permissão para estacionar) a 5,15 m (na linha de retenção), trecho plano e curva horizontal em declive a $6,30 \mathrm{~m}$ da linha de retenção. O equipamento ASV 122 trabalha em conjunto com a aproximação fiscalizada pelo equipamento ASV 121. A largura do cruzamento é de $10,5 \mathrm{~m}$ (três faixas de trânsito).

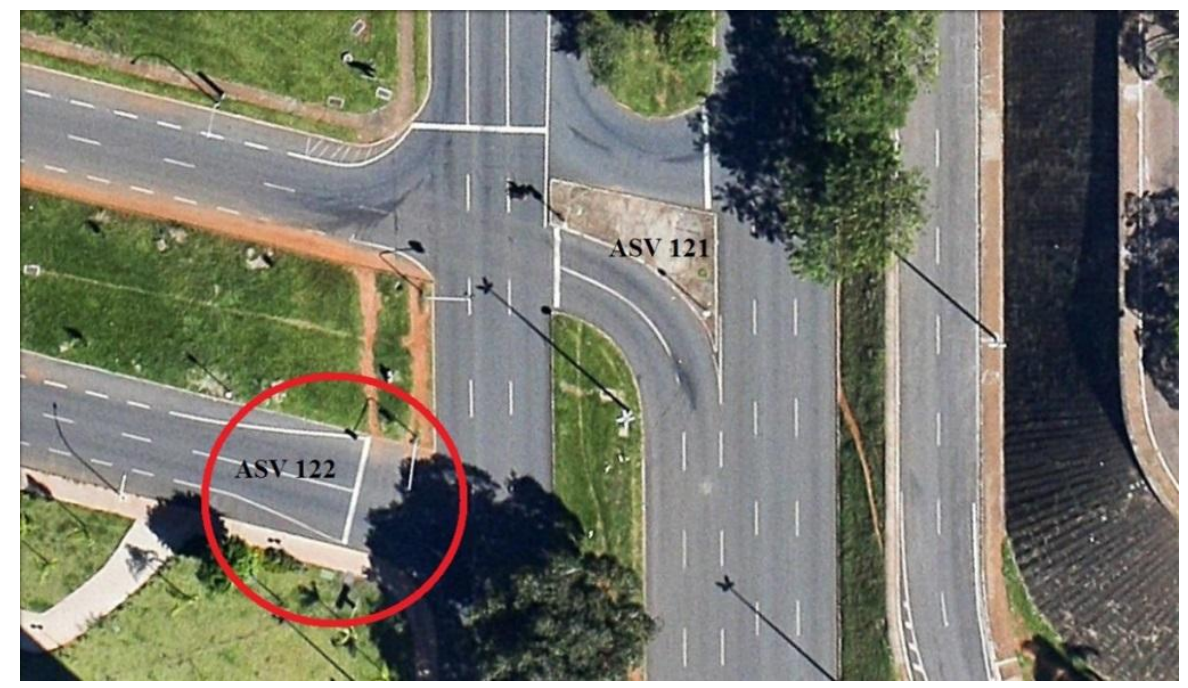

Figura 5.9: Imagem de satélite da aproximação fiscalizada pelo equipamento ASV 122 
Apesar da sinalização horizontal, o limite do estacionamento é frequentemente descumprido, conforme mostra a Figura 5.10. Alguns condutores ultrapassam até mesmo a linha de retenção.

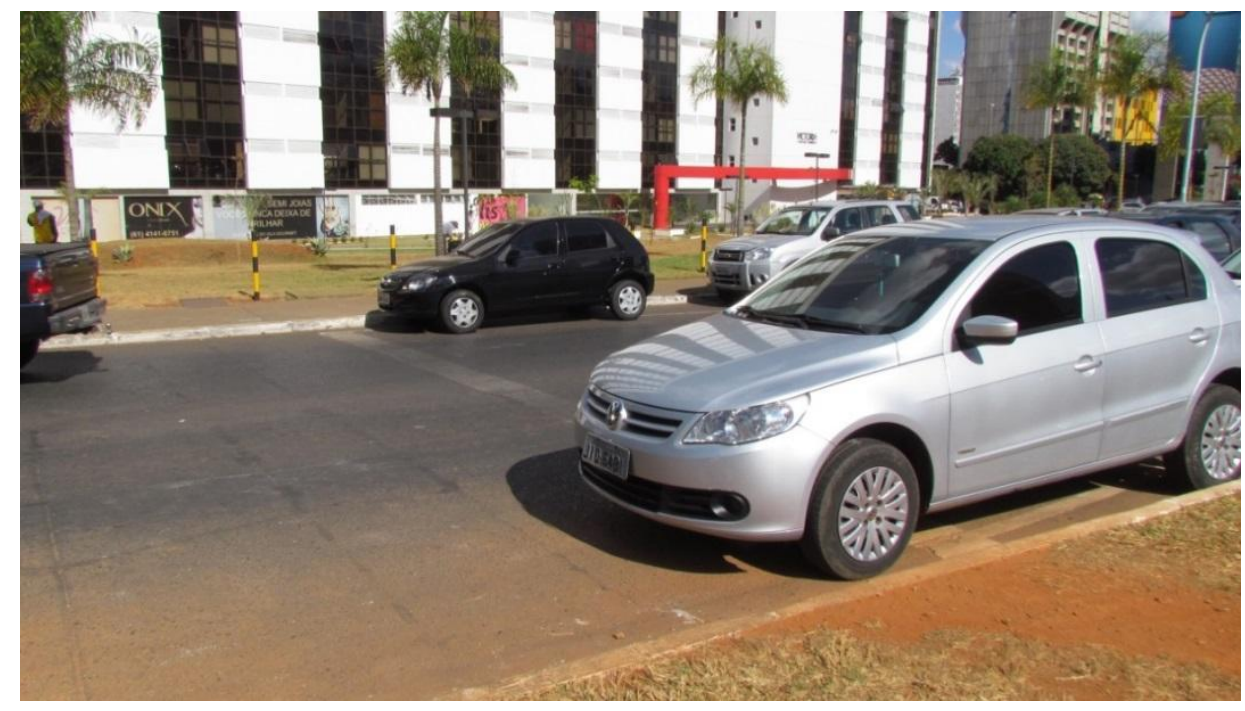

Figura 5.10: Veículos estacionados irregularmente

Foto: O autor, 2014.

Na Figura 5.11 observam-se dois focos semafóricos instalados antes da via transversal em um mesmo suporte, um posicionado na coluna e o outro no braço projetado. O foco semafórico apresenta anteparo, pestana e luz LED com tamanho de $30 \mathrm{~cm}$ para indicação vermelha.

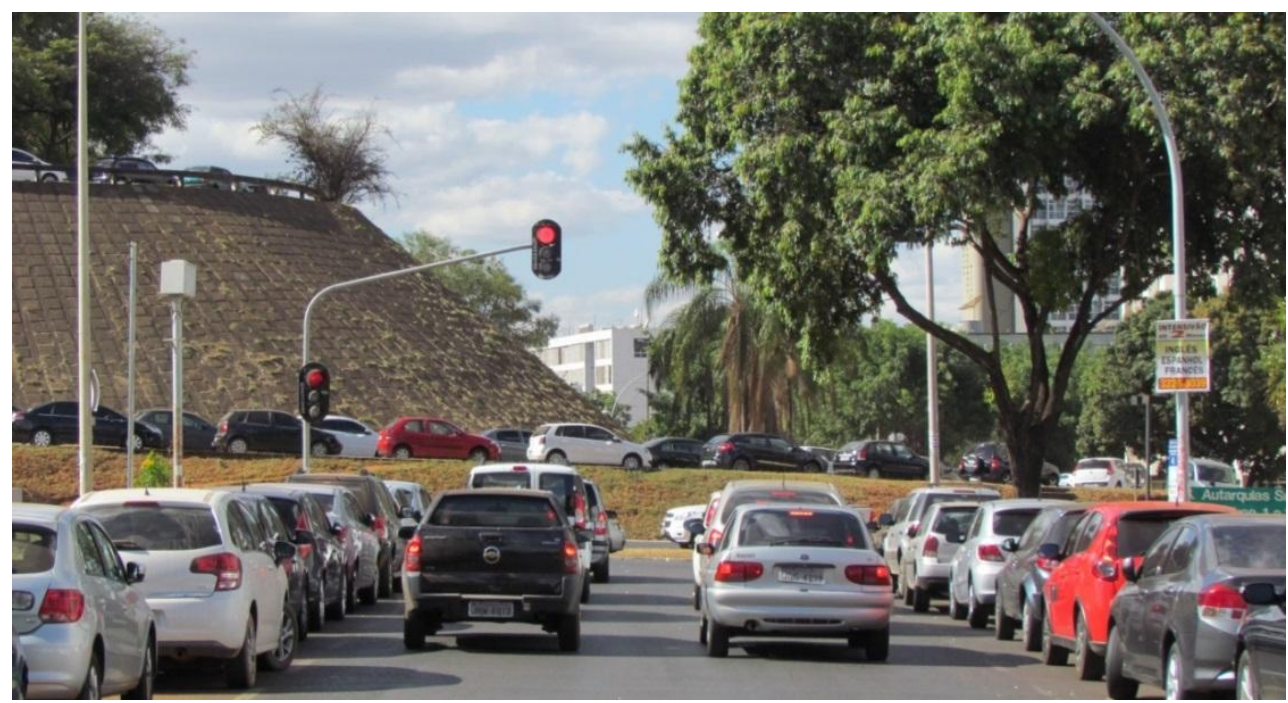

Figura 5.11: Vista da aproximação fiscalizada pelo equipamento ASV 122

Foto: O autor, 2014.

A programação semafórica da aproximação é de $20 \mathrm{~s}$ de verde, $3 \mathrm{~s}$ de amarelo e $45 \mathrm{~s}$ de vermelho (igual ao ASV 121). O tempo de vermelho geral do cruzamento é de 2 s e o tempo 
total do ciclo, de 68 s, com dois estágios. Predominam os automóveis, e não há linha de ônibus. Foram observados caminhões de pequeno porte. A aproximação possui, a montante, via com velocidade regulamentada de $50 \mathrm{~km} / \mathrm{h}$ e, a jusante, via com velocidade regulamentada de $60 \mathrm{~km} / \mathrm{h}$.

\subsubsection{ASV 143}

A interseção tem três faixas de trânsito de 3,5 m cada - sendo uma delas (a da direita) livre -, trecho plano e aproximação em curva horizontal. A largura do cruzamento é de $13 \mathrm{~m}$. A retenção a jusante do semáforo ocorre para acesso a um retorno localizado no canteiro central. Caso contrário, o condutor terá que percorrer $320 \mathrm{~m}$ para acessar o próximo retorno, como mostra a Figura 5.12. A interseção separa as regiões Guará I e II.

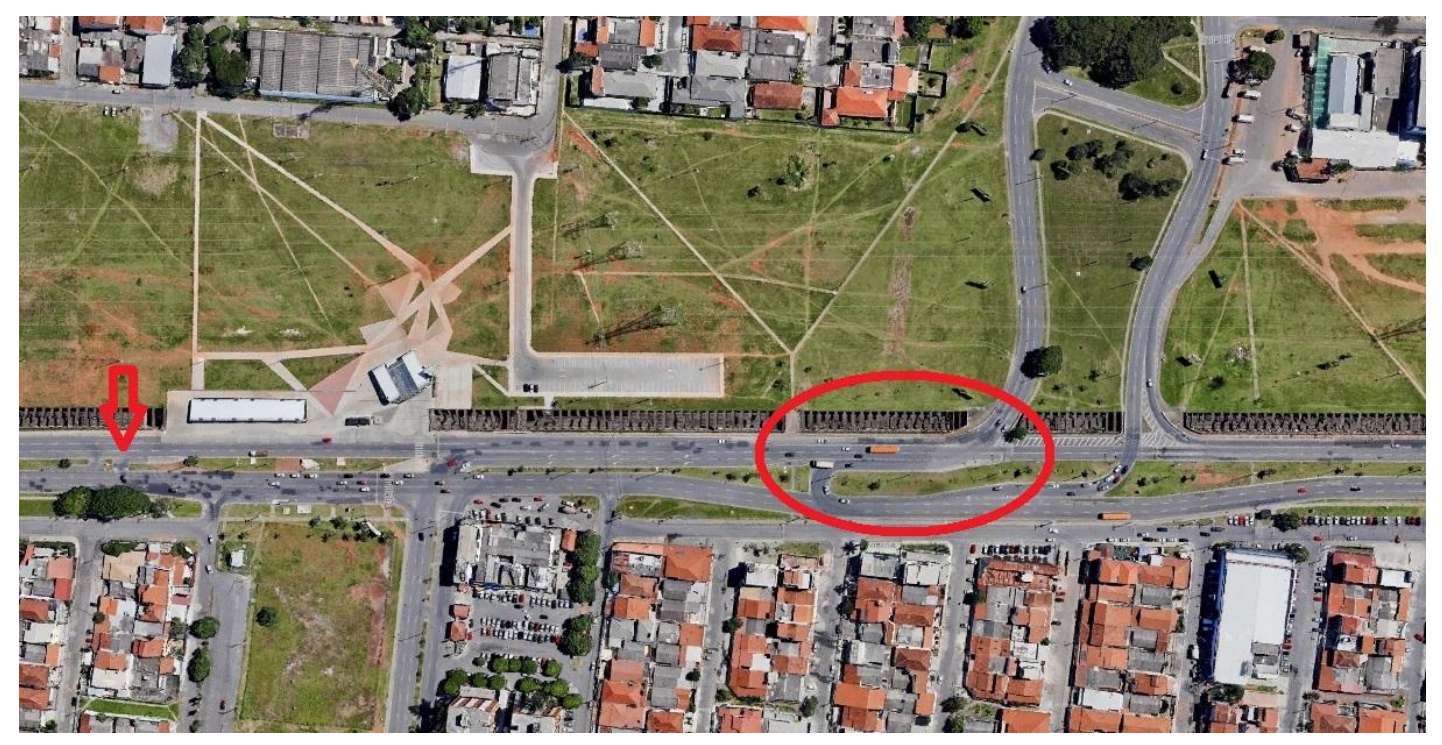

Figura 5.12: Imagem de satélite da aproximação fiscalizada pelo equipamento ASV 143

A Figura 5.13 mostra dois focos semafóricos instalados em um único suporte localizado após a via transversal, um posicionado na coluna e o outro no braço projetado. O foco semafórico apresenta anteparo, pestana e luz LED com tamanho de $30 \mathrm{~cm}$ para indicação vermelha. É possível verificar veículo bloqueando o cruzamento, bem como a ausência de sinalização horizontal de marcação de área de conflito. 


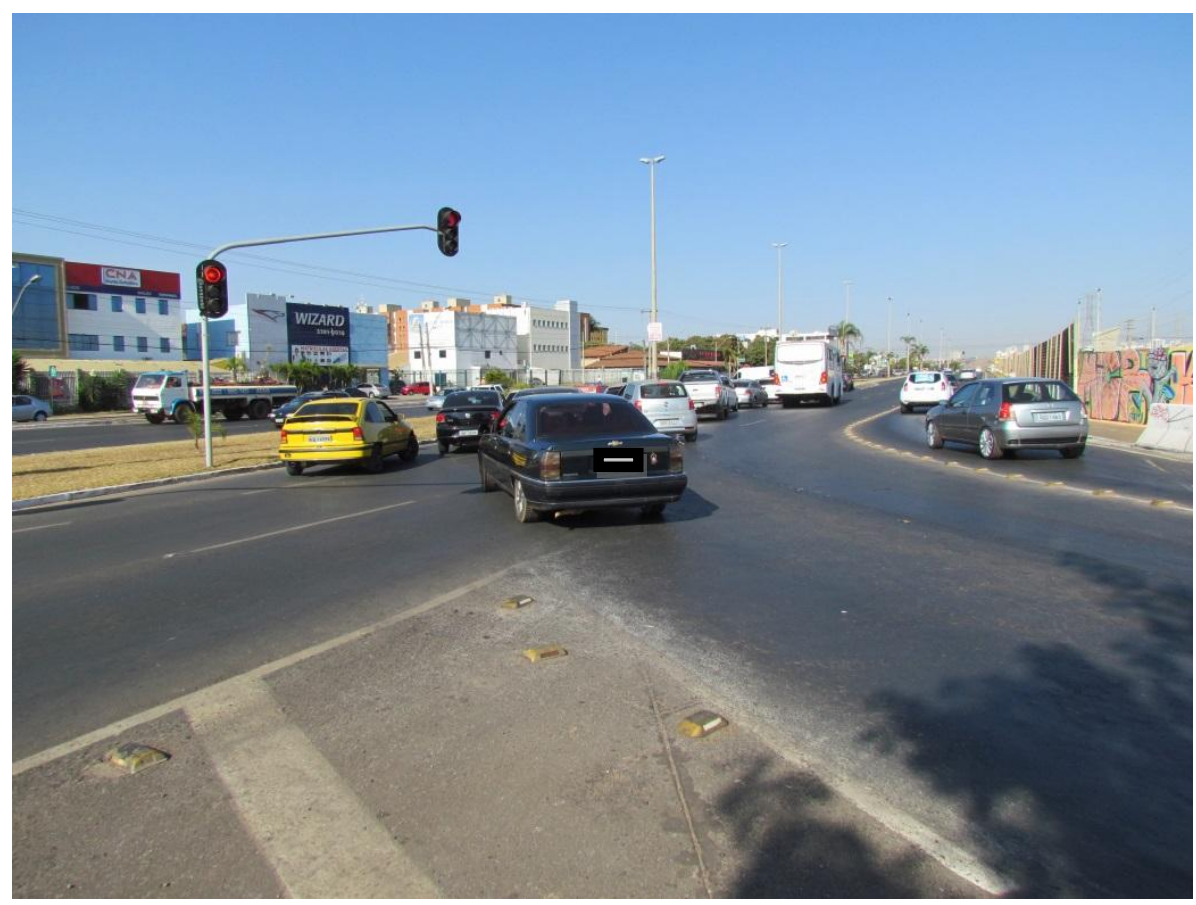

Figura 5.13: Vista da aproximação fiscalizada pelo equipamento ASV 143

Foto: O autor, 2014.

Observou-se que os condutores da via transversal, quando bloqueados pelos veículos que ocupam o cruzamento - que incluem ônibus urbanos -, passam a trafegar na faixa sinalizada com linhas de canalização, o que pode acarretar acidentes.

A programação semafórica da aproximação é de $50 \mathrm{~s}$ de verde, $3 \mathrm{~s}$ de amarelo e $54 \mathrm{~s}$ de vermelho. O tempo de vermelho geral do cruzamento é de 2 s e o tempo total do ciclo, de 107 s, com dois estágios. Há predomínio de automóveis e a presença de linhas de ônibus. Foram observados caminhões de pequeno porte. A aproximação possui velocidade regulamentada de $60 \mathrm{~km} / \mathrm{h}$.

\subsubsection{ASV 045}

A interseção conta com duas faixas de trânsito de 3,4 m cada, em declive e aproximação em curva horizontal. O cruzamento dá-se por um entrelaçamento com outra aproximação, conforme pode ser visualizado na Figura 5.14. 

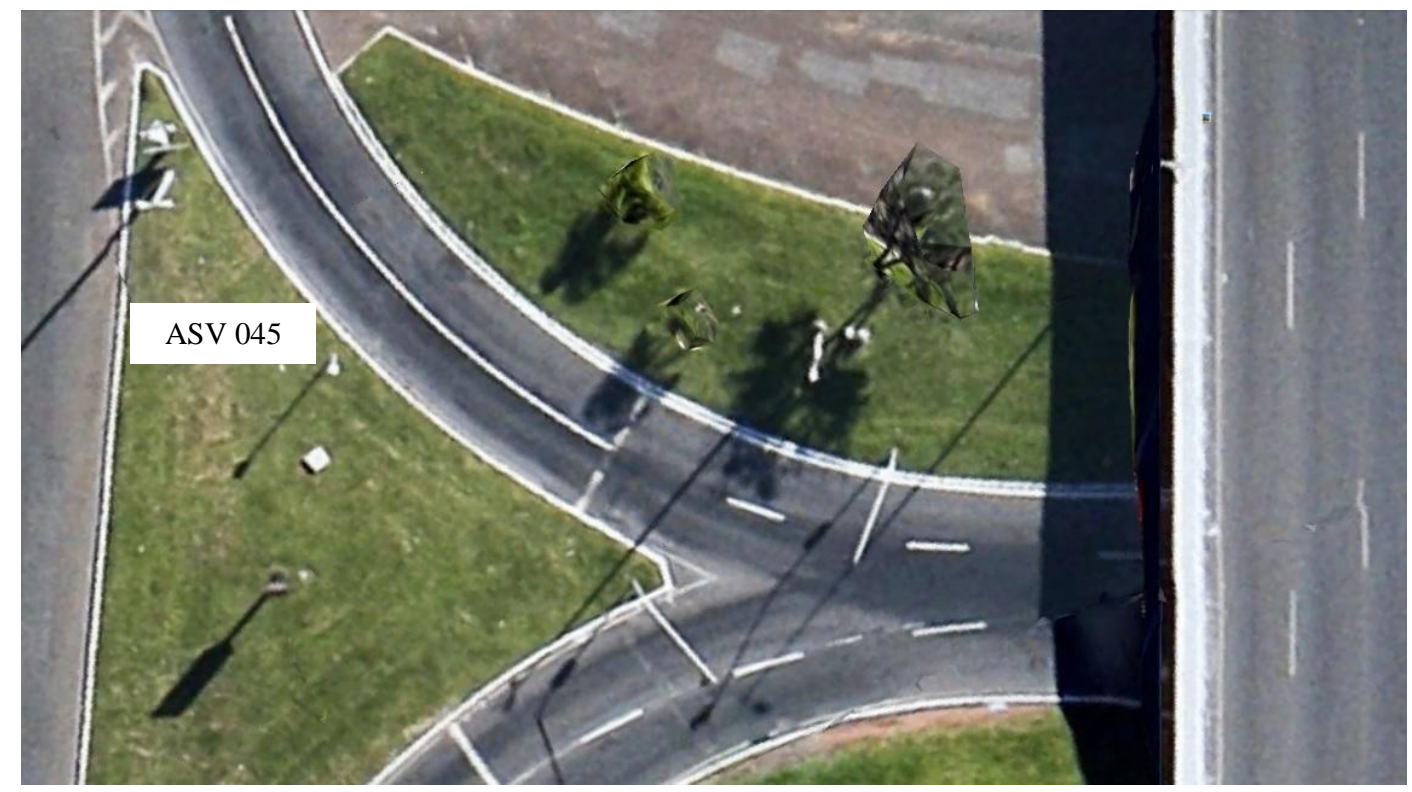

Figura 5.14: Imagem de satélite da aproximação fiscalizada pelo equipamento ASV 045

A programação semafórica da aproximação é de 1 min $33 \mathrm{~s}$ de verde, $3 \mathrm{~s}$ de amarelo e 1 min $28 \mathrm{~s}$ de vermelho. O tempo de vermelho geral do cruzamento é de $2 \mathrm{~s}$ e o tempo total do ciclo, de 3 min 4 s, com dois estágios. A Figura 5.15 exibe dois focos semafóricos instalados em um único suporte localizado antes do entrelaçamento, um posicionado na coluna e o outro no braço projetado. O foco semafórico apresenta anteparo, pestana e luz LED com tamanho de $30 \mathrm{~cm}$ para indicação vermelha.

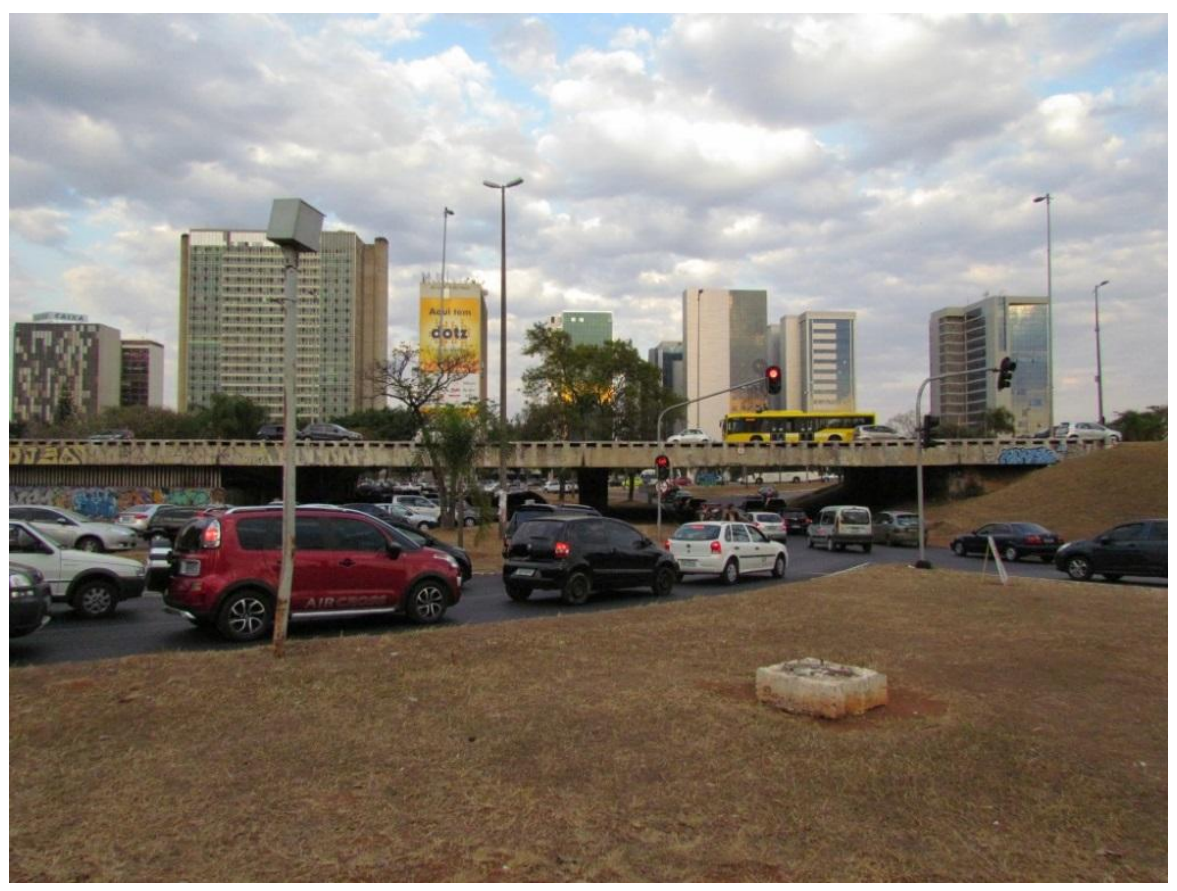

Figura 5.15: Vista da aproximação fiscalizada pelo equipamento ASV 045

Foto: O autor, 2014. 
Observou-se que os veículos chegam em pelotão na mudança da indicação amarela, e a indicação verde trabalha quase metade do tempo ociosa. A Figura 5.16 permite visualizar o trajeto dos veículos em pelotão.

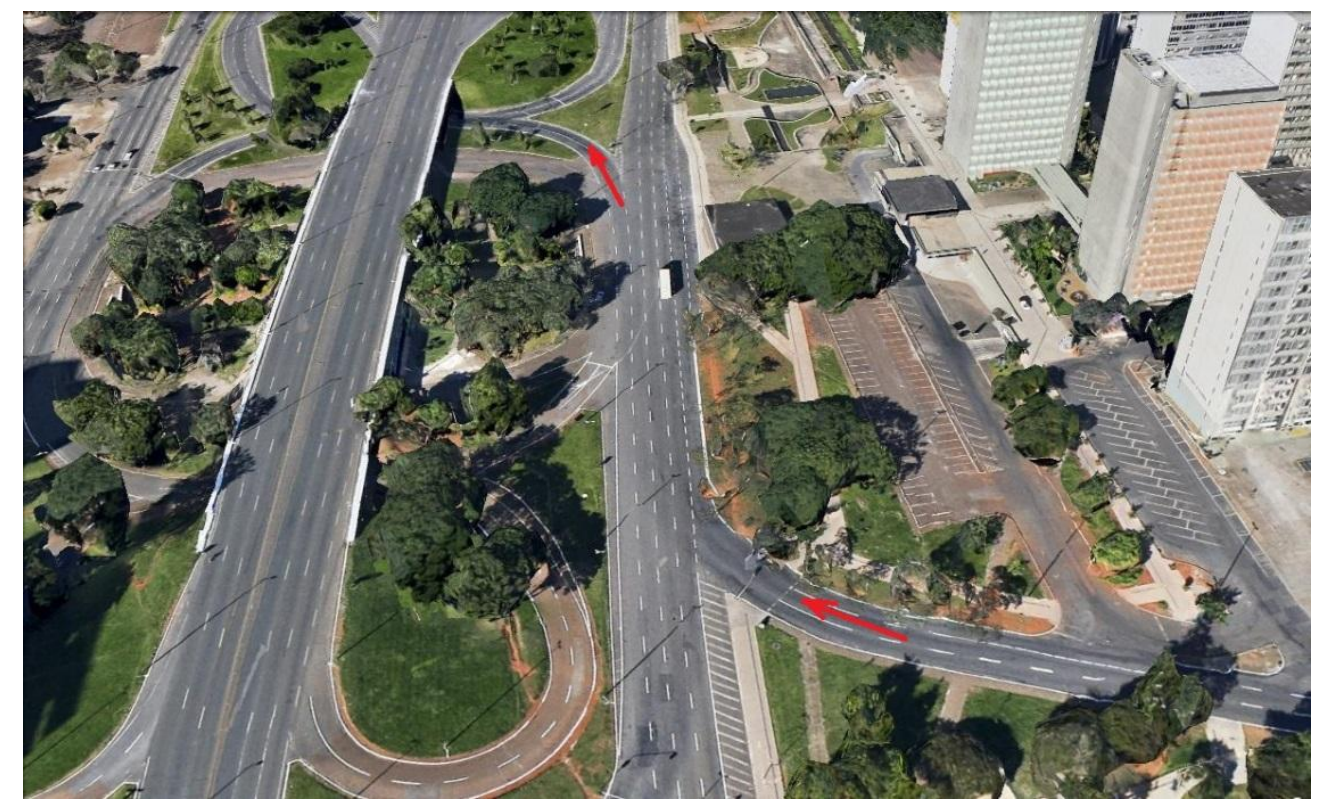

Figura 5.16: Imagem de satélite com indicação do trajeto de veículos em coordenação semafórica

\subsection{SÍNTESE DOS RESULTADOS}

Como forma de sintetizar as informações obtidas e comparar cada uma das interseções, a Tabela 5.1 apresenta as características gerais de geometria, sinalização e elementos de programação semafórica.

Comparativamente aos índices apresentados na Tabela 3.1 (que variaram de 13,2 a 53 infrações a cada 10 mil veículos), com exceção do ASV 121, que foi de 81 infrações a cada 10 mil veículos, todos os outros ficaram abaixo, estando os pontos discrepantes no intervalo de 18 a 27 infrações a cada 10 mil veículos e os pontos extremos acima de 27 infrações a cada 10 mil veículos. Porém, cabe observar que as interseções urbanas estudadas no Distrito Federal já são fiscalizadas eletronicamente, diferentemente das cidades citadas na Tabela 3.1. 
Tabela 5.1: Características gerais de geometria, sinalização e elementos de programação semafórica

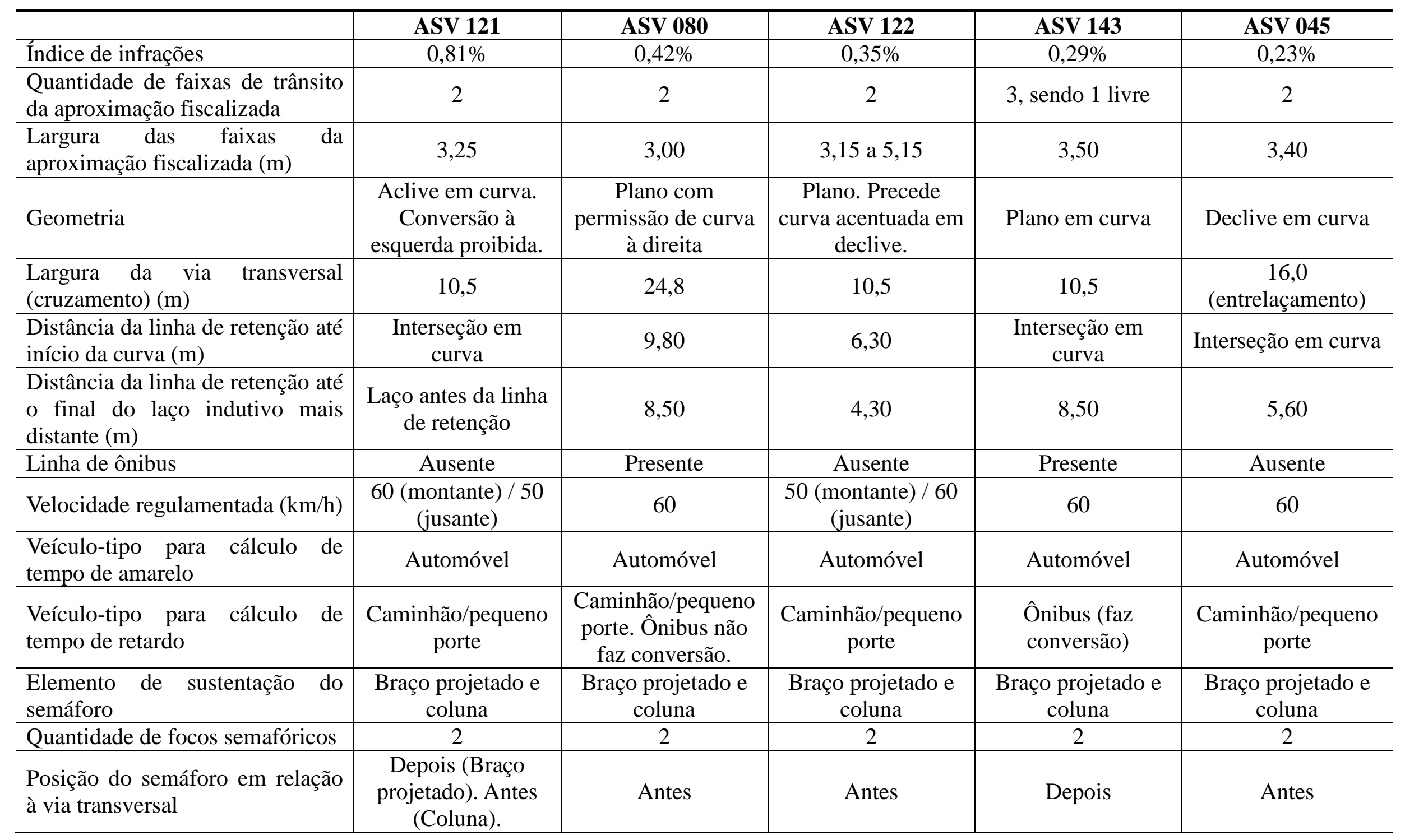


Tabela 5.1: Continuação

\begin{tabular}{|c|c|c|c|c|c|}
\hline & ASV 121 & ASV 080 & ASV 122 & ASV 143 & ASV 045 \\
\hline Anteparo & $\begin{array}{l}\text { Presente no suporte } \\
\text { projetado } \\
\text { (obrigatório) e na } \\
\text { coluna (opcional) }\end{array}$ & $\begin{array}{l}\text { Presente no suporte } \\
\text { projetado } \\
\text { (obrigatório) e na } \\
\text { coluna (opcional) }\end{array}$ & $\begin{array}{c}\text { Presente no suporte } \\
\text { projetado } \\
\text { (obrigatório) e na } \\
\text { coluna (opcional) }\end{array}$ & $\begin{array}{l}\text { Presente no suporte } \\
\text { projetado } \\
\text { (obrigatório) e na } \\
\text { coluna (opcional) }\end{array}$ & $\begin{array}{l}\text { Presente no suporte } \\
\text { projetado } \\
\text { (obrigatório) e na } \\
\text { coluna (opcional) }\end{array}$ \\
\hline $\begin{array}{l}\text { Pestana e luz de LED de } 30 \mathrm{~cm} \\
\text { para indicação vermelha }\end{array}$ & Sim & Sim & Sim & Sim & Sim \\
\hline Luz vermelha repetida & Não & Não & Não & Não & Não \\
\hline Tempo de vermelho (s) & 45 & 192 & 45 & 54 & 88 \\
\hline Tempo de vermelho geral (s) & 2 & 2 & 2 & 2 & 2 \\
\hline Tempo de amarelo (s) & 3 & 3 & 3 & 3 & 3 \\
\hline
\end{tabular}

Fonte: Elaborado pelo autor, 2014. 


\subsubsection{Tempo de entreverdes}

Com base no manual Sinalização semafórica (CONTRAN, 2014), foi calculado o tempo de entreverdes para as interseções estudadas (ver Apêndice A). O valor arredondado a partir do cálculo foi adotado em comparação com o obtido in loco. A Tabela 5.2 sintetiza os parâmetros de cálculo e os resultados encontrados.

Observa-se que, em todas as aproximações, o tempo de amarelo calculado e adotado pelo arredondamento é de $4 \mathrm{~s}$ e o tempo in loco é de $3 \mathrm{~s}$, menor que o necessário para que o condutor possa frear o veículo com segurança, ainda que nas aproximações fiscalizadas pelos equipamentos ASV 121, ASV 122 e ASV 143 o tempo de entreverdes in loco seja igual ao adotado. A respeito disso, Yang, Han e Cherry (2013) entendem que o número de acidentes em ângulo reto diminui com o tempo de entreverdes correto, porém o tempo de amarelo menor que o necessário provoca um aumento no número de infrações. Acrescenta-se que o número de colisões traseiras pode aumentar em função da possível indecisão do condutor em não conseguir frear com segurança.

Para as aproximações fiscalizadas pelos equipamentos ASV 080 e ASV 045, o tempo de entreverdes é menor, o que pode comprometer a frenagem do veículo com segurança ou fazer com que o veículo abandone a área de conflito antes que movimentos conflitantes recebam direito de passagem.

Ademais, conforme o manual Sinalização semafórica (CONTRAN, 2014), o tempo mínimo de amarelo para vias com velocidades regulamentadas de $50 \mathrm{~km} / \mathrm{h}$ e $60 \mathrm{~km} / \mathrm{h}$ é de $4 \mathrm{~s}$, parâmetro não atendido em nenhuma das interseções estudadas. 
Tabela 5.2: Cálculo do tempo de entreverdes

\begin{tabular}{|c|c|c|c|c|c|}
\hline & ASV 121 & ASV 080 & ASV 122 & ASV 143 & ASV 045 \\
\hline Velocidade regulamentada $(\mathrm{km} / \mathrm{h})$ & 60 & 60 & 50 & 60 & 60 \\
\hline Tempo de vermelho geral calculado (s) & 0,9 & 2,2 & 1,6 & 1,2 & 1,3 \\
\hline Tempo de entreverdes calculado (s) & 4,3 & 6,0 & 4,9 & 5,0 & 5,3 \\
\hline Tempo de entreverdes adotado (s) & 5,0 & 6,0 & 5,0 & 5,0 & 6,0 \\
\hline Tempo de amarelo in loco $(\mathrm{s})$ & 3,0 & 3,0 & 3,0 & 3,0 & 3,0 \\
\hline Tempo de vermelho geral adotado (s) & 1,0 & 2,0 & 1,0 & 1,0 & 2,0 \\
\hline Tempo de vermelho geral in loco (s) & 2,0 & 2,0 & 2,0 & 2,0 & 2,0 \\
\hline
\end{tabular}

Fonte: Elaborado pelo autor, 2014. 


\subsubsection{Tempo de retardo}

Com base na metodologia proposta por Filizola, Pelisson e Silva (2014), foi calculado o tempo de retardo para as interseções estudadas (Tabela 5.3).

Tendo em vista que alguns equipamentos estão localizados no final de trechos em curva (ASV 121 e ASV 045), a velocidade praticada e a velocidade da curva de conversão foram consideradas iguais e obtidas pelos dados dos próprios equipamentos ( 85 percentil). No caso do ASV 143, ainda que esteja em trecho curvo, os condutores que cruzam a linha de retenção necessitam fazer nova conversão após o cruzamento da via transversal. A velocidade praticada é de 85 percentil e a velocidade de projeto da curva de conversão é de $15 \mathrm{~km} / \mathrm{h}$, segundo o DNIT (2005 apud FILIZOLA, PELISSON e SILVA, 2014).

Para os equipamentos ASV 080 e ASV 122, que estão em trecho reto e precedem curvas, a pesquisa de campo adotou a velocidade regulamentada da via por não dispor da velocidade praticada.

O comprimento do veículo-tipo foi adotado conforme regulamentação do DNIT (2010 apud FILIZOLA, PELISSON e SILVA, 2014), sendo: veículo de passeio $=5,80 \mathrm{~m}$; veículo comercial $=9,10 \mathrm{~m}$; ônibus $=12,20 \mathrm{~m}$. A velocidade de projeto da curva de conversão, de 15 $\mathrm{km} / \mathrm{h}$, também segue o manual do DNIT. 
Tabela 5.3: Cálculo do tempo de retardo

\begin{tabular}{|c|c|c|c|c|}
\hline & ASV 080 & ASV 122 & ASV 143 & ASV 045 \\
\hline Velocidade regulamentada $(\mathrm{km} / \mathrm{h})$ & 60 & 50 & 60 & 60 \\
\hline Velocidade praticada -85 percentil $(\mathrm{km} / \mathrm{h})$ & 60 (adotado) & 50 (adotado) & 28 & 35 \\
\hline Velocidade de projeto da curva de conversão $(\mathrm{km} / \mathrm{h})$ & 15 & 15 & 15 & 35 \\
\hline Distância da linha de retenção até o início da curva (m) & 9,80 & 6,30 & $\begin{array}{l}17 \text { (após via } \\
\text { transversal) }\end{array}$ & Em curva \\
\hline $\begin{array}{l}\text { Distância da linha de retenção até o final do laço indutivo mais } \\
\text { distante }(\mathrm{m})\end{array}$ & 8,50 & 4,30 & 8,50 & 5,60 \\
\hline Veículo de projeto ou tipo $(\mathrm{m})$ & 9,10 & 9,10 & 12,20 & 9,10 \\
\hline Tempo de retardo adotado $(\mathrm{s})$ & 1 & 1 & 1 & 1 \\
\hline Tempo de retardo mínimo calculado $(\mathrm{s})$ & 2 & 2 & 3 & 2 \\
\hline Percentual de infrações abaixo do tempo calculado (Tabela 4.8) & $47 \%$ & $63 \%$ & $74 \%$ & $33 \%$ \\
\hline
\end{tabular}

Fonte: Elaborado pelo autor, 2014.

*Não foi possível calcular o tempo de retardo para o equipamento ASV 121 em razão dos laços indutivos terem sido instalados antes da linha de retenção. 
Na Tabela 5.3 é possível observar que o tempo de retardo de $1 \mathrm{~s}$, adotado indistintamente para todas as interseções semaforizadas fiscalizadas sem projeto-tipo, em não atendimento ao que especifica a Portaria Denatran $n^{\circ}$ 16/2004 (DENATRAN, 2004), afeta a quantidade de infrações e prejudica a legalidade da fiscalização.

Com base em cem autos de infração aleatórios para cada equipamento, o percentual do tempo de passagem dos veículos a partir da indicação vermelha revela uma variação de $33 \%$ (ASV 045) a 74\% (ASV 143) de infrações que não deveriam ter sido emitidas, conforme a metodologia proposta e os parâmetros adotados.

Em relação aos equipamentos ASV 080 e ASV 122, para os quais foi adotada a velocidade máxima regulamentada como velocidade praticada, caso fosse considerada a velocidade mínima permitida para a via (metade da máxima regulamentada), o tempo de retardo aumentaria de $2 \mathrm{~s}$ para $3 \mathrm{~s}$ para o equipamento ASV 080. Além disso, o percentual de infrações que não deveriam ter sido emitidas com base nos autos de infração aleatórios seria de 64\%, não de 47\%. Para o equipamento ASV 122 não houve variação.

Com relação ao equipamento ASV 121, o laço indutivo antes da linha de retenção não só prejudica o cálculo do tempo de retardo, como também se apresenta como a melhor explicação plausível que justifique o elevado índice de infrações para esse equipamento nas bases do Sig-Detran/DF.

\subsubsection{Síntese dos principais problemas detectados}

Com base nas referências pesquisadas e nos resultados obtidos, foi elaborado o Quadro 5.1, que sintetiza os problemas identificados e as respectivas contramedidas de engenharia. 
Quadro 5.1: Síntese dos problemas identificados e das respectivas contramedidas de engenharia

\begin{tabular}{|c|c|c|}
\hline & PROBLEMA IDENTIFICADO & CONTRAMEDIDA DE ENGENHARIA \\
\hline ASV 121 & $\begin{array}{l}\text { 1. Laços indutivos antes da linha de retenção. 2. Tempo de } \\
\text { amarelo e tempo de retardo menores que o calculado e tempo } \\
\text { de verde de } 20 \mathrm{~s} \text { com retenção a jusante. } 3 \text {. Faixa de pedestre } \\
\text { após a interseção causando retenção. } 4 \text {. Visibilidade do } \\
\text { semáforo prejudicada por veículos pesados (coluna) e por } \\
\text { curva acentuada (braço projetado após via transversal). 5. } \\
\text { Veículos estacionados irregularmente prejudicam a capacidade } \\
\text { da interseção. 6. Veículos fazem conversão proibida à } \\
\text { esquerda. }\end{array}$ & $\begin{array}{l}\text { 1. Realocar linha de retenção e/ou laços indutivos. 2. Rever a } \\
\text { programação semafórica completa. 3. Analisar semaforização da } \\
\text { faixa de pedestre coordenada com o semáforo da interseção. } 4 . \\
\text { Realocar foco semafórico e/ou alterar elemento de sustentação. } 5 . \\
\text { Adotar contramedida de fiscalização (fiscalizar estacionamento } \\
\text { irregular). 6. Adotar contramedida de fiscalização (Art. } 207 \text { - } \\
\text { executar operação de conversão à direita ou à esquerda em locais } \\
\text { proibidos pela sinalização, conforme Portaria Denatran } n^{\circ} \\
\text { 263/2007) (DENATRAN, 2007). }\end{array}$ \\
\hline ASV 080 & $\begin{array}{l}\text { 1. Tempo de amarelo e tempo de retardo menores que o } \\
\text { calculado. 2. Início de verde da aproximação com caixa a } \\
\text { jusante congestionada. 3. Movimentos ociosos. 4. Capacidade } \\
\text { da interseção esgotada. 5. Sinalização horizontal de marcação } \\
\text { de área de conflito e linha de retenção apagada. 6. } \\
\text { Estacionamento regulamentado ao longo da via, causando } \\
\text { atrasos na interseção. }\end{array}$ & $\begin{array}{l}\text { 1. Corrigir tempo de amarelo e tempo de retardo. 2. Melhorar } \\
\text { coordenação semafórica. 3. Otimizar ciclo semafórico. } 4 . \\
\text { Contemplar estudo de novo projeto viário (p. ex. binário). } 5 . \\
\text { Revitalizar sinalização horizontal. 6. Considerar proibição de } \\
\text { estacionamento em um dos lados da via e/ou elaborar novo projeto } \\
\text { viário. }\end{array}$ \\
\hline ASV 045 & $\begin{array}{l}\text { 1. Tempo de amarelo e tempo de retardo menores que o } \\
\text { calculado. 2. Veículos chegam em pelotão na mudança do } \\
\text { amarelo. 3. Ciclo de verde parcialmente ocioso. }\end{array}$ & $\begin{array}{l}\text { 1. Corrigir tempo de amarelo e tempo de retardo. 2. Melhorar a } \\
\text { coordenação semafórica. } 3 \text {. Otimizar ciclo semafórico. }\end{array}$ \\
\hline
\end{tabular}

Fonte: Elaborado pelo autor, 2014. 
Cabe lembrar que, em situações de congestionamento a jusante do semáforo, o órgão de trânsito estabelece que condutores que cruzaram a linha de retenção na indicação verde ou amarela possuem $10 \mathrm{~s}$ para retroceder o veículo antes que sejam autuados por bloquear o cruzamento e, caso prossigam, são autuados por avançar o sinal vermelho. A correta caracterização da infração de ASV, nos termos da Portaria Denatran n n $^{\circ}$ 16/2004 (DENATRAN, 2004) - somente para veículos que tenham recebido a indicação luminosa vermelha antes da faixa de retenção da aproximação fiscalizada -, afeta a quantidade de infrações e não é citada nas referências de contramedidas por ser considerada uma premissa básica.

O tempo de retardo adotado de $1 \mathrm{~s}$ para todos os 123 equipamentos sem estudo específico para cada local, bem como o posicionamento correto do laço indutivo após a linha de retenção para o equipamento ASV 121, também não são citados nas referências de contramedidas de engenharia. Optou-se, porém, por inseri-los no Quadro 5.1 por ter sido possível calcular o tempo de retardo correto e apresentar a justificativa, no caso do equipamento ASV 121, do elevado índice de infrações. 


\section{CONSIDERAÇÕES FINAIS}

\subsection{OBJETIVOS DO TRABALHO}

O presente trabalho atendeu aos objetivos propostos, identificando e analisando os fatores viários que afetam o desrespeito à sinalização de trânsito em avançar o sinal vermelho do semáforo, bem como as respectivas contramedidas de engenharia com foco na redução do número de infrações.

A hipótese de que, nas interseções selecionadas e com base no índice de infrações aplicadas, há fatores específicos que dificultam aos condutores a obediência à fiscalização eletrônica e que são mais "fortes" que os impactos previstos por essa fiscalização, foi confirmada com a identificação de fatores viários e respectivas contramedidas de engenharia, ainda que parte das infrações observadas pelos autos de infração digam respeito a medidas de fiscalização (veículos que cruzam a linha de retenção acima de $10 \mathrm{~s}$ após a indicação vermelha).

\subsection{USO DA FISCALIZAÇÃO ELETRÔNICA}

Ainda que o presente trabalho adote como estudo de caso interseções que já estão sendo fiscalizadas eletronicamente, entende-se que as contramedidas de engenharia citadas na revisão da literatura visam a contribuir para a redução do número de infrações (em contraposição a buscar essa redução via medidas de fiscalização) e a fiscalização só pode ser realizada em locais com características físicas e de controle semafórico que permitam ao condutor evitar a infração.

Apesar da legislação brasileira ainda não regulamentar estudos de instalação e avaliação da eficácia de sistemas automáticos não metrológicos de fiscalização para ASV, considera-se que contramedidas de fiscalização são mais efetivas quando as decisões do condutor acerca de ASV são evitáveis. Assim, é possível concluir que a fiscalização de ASV, incluindo a eletrônica, deve ser precedida da adoção de contramedidas de engenharia que tornem evitável o ASV.

Cabe esclarecer que o sentido de se realizar estudo técnico não pode ser distorcido de modo a colocar em dúvida a fiscalização de condutas inadequadas, que pode ocorrer em qualquer interseção. É recomendável que o órgão priorize, em função dos recursos disponíveis 
existentes, a instalação em locais críticos com altos índices de infrações e/ou UPS de acidentes elevada, utilizando esses mesmos parâmetros para avaliação da eficácia do equipamento.

Metas de redução de infrações poderiam ser estabelecidas para nortear as ações dos órgãos executivos de trânsito (projetos de engenharia, campanhas educativas etc.), em consonância com a Resolução Contran $n^{\circ}$ 166/2004 (CONTRAN, 2004b), que recomenda que a arrecadação financeira resultante de multas seja desejavelmente decrescente. Tais metas visam também a melhorar o acompanhamento das informações e a aceitação dos equipamentos de fiscalização por parte da sociedade.

\subsection{ESTUDO DE CASO}

Todas as cinco aproximações fiscalizadas apresentaram problemas que afetaram a quantidade de infrações por ASV e, com base nas referências consultadas, foi possível identificar as respectivas contramedidas de engenharia.

Categorias de contramedidas como operação do semáforo, informação ao condutor e melhorias físicas descritas nas referências balizaram a indicação de contramedidas específicas. Entretanto, outras falhas foram encontradas, como colocação indevida dos laços indutivos antes da linha de retenção, tempo de retardo menor que o necessário e caracterização incorreta da infração de ASV.

Os dados fornecidos pelos equipamentos de fiscalização inseridos no Sig-Detran/DF mostraram-se úteis, mas observou-se que outras informações importantes apresentadas diretamente pela empresa contratada para execução dos serviços não fazem parte do banco de dados do órgão executivo de trânsito. A não utilização desses dados e o risco de perder essas informações caso haja novo contratado prejudica o histórico de dados e o consequente direcionamento de ações de educação, engenharia e fiscalização.

Como exemplo de dados obtidos em fontes que não o Sig-Detran/DF e de relevância para um estudo da interseção, podem-se citar: diferenciação por tipo de infração (ASV, PSF ou VAL), quantidade de infrações por tipo de veículo, hora-pico de infrações, índice de infrações por 
faixa de trânsito etc. Informações como o tempo de passagem do veículo após a indicação vermelha do semáforo, obtidas em autos de infração, poderiam ser sistematizadas.

Cabe salientar o cumprimento da Portaria Denatran $n^{\circ}$ 16/2004 em razão da questão da legalidade para emissão de infrações, da correta caracterização do ASV e da necessidade de estudo específico em cada local para o correto cálculo do tempo de retardo, o que não foi atendido nas interseções analisadas. A mesma atenção deve ser dada para o tempo de amarelo de forma a possibilitar ao condutor parar o veículo com segurança.

Com relação à metodologia empregada, recomenda-se que a visita in loco seja realizada não somente na hora-pico de infrações como também na hora-pico do fluxo de tráfego, as quais neste estudo não foram coincidentes. $O$ índice de infrações por faixa de trânsito permite uma análise mais precisa da aproximação do que aquela pautada no percentual de infrações por faixa.

\subsection{ESTUDOS POSTERIORES}

Recomenda-se como continuação a sistematização do procedimento utilizado neste trabalho para auxiliar órgãos de trânsito na verificação das condições viárias para avaliação da eficácia do EFE para ASV.

Salienta-se que os EFEs já estavam instalados, porém entende-se interessante que estudos posteriores definam uma metodologia para uma dada interseção sem fiscalização eletrônica e que, dentre diversas contramedidas possíveis, avaliem se a contramedida de fiscalização (implantar o EFE) é indicada ou não.

Pesquisas futuras podem estudar interseções com baixos índices de infrações e extrair as características viárias que favoreçam o cumprimento da sinalização por parte do condutor, além de considerar índices que levem em conta não só a quantidade de infrações em relação à quantidade de veículos como também o número de ciclos do semáforo para comparação entre as interseções. Outros dados não considerados neste trabalho, tais como a PSF e a VAL e o modo como afetam o ASV, também merecem atenção nesse tema. 


\section{REFERÊNCIAS}

AL-ATAWI, A. M. (2014) Characteristics of red light running violations in urban areas in Tabuk, Kingdom of Saudi Arabia. IATSS Research, v. 37, p. 119-123.

BBC Brasil (2014) Arábia Saudita prende motoristas que furarem sinal. Disponível em: <http://www.bbc.co.uk/portuguese/noticias/2014/09/140924_arabia_saudita_sinal_vermelho_rm>. Acesso em: 26 set. 2014.

Bocanegra, C. W. R. (2006) Procedimentos para implantação e avaliação do desempenho de lombadas eletrônicas em áreas urbanas. 149 f. Tese (Doutorado em Engenharia de Produção) - Programa de PósGraduação em Engenharia de Produção, Universidade Federal do Rio Grande do Sul, Porto Alegre.

Bonneson, J.; Zimmerman, K. e Brewer, M. (2002) Engineering countermeasures to reduce red-light running. Texas Transportation Institute. Report 4027-2. Project 0-4027.

Bonneson, J. e Zimmerman, K. (2004) Red-light-running handbook: an engineer's guide to reducing red-lightrelated crashes. Texas Transportation Institute. Product 0-4196-P1. Project 0-4196.

Brasil (1997) Lei n 9.503, de 23 de setembro de 1997. Institui o Código de Trânsito Brasileiro. Diário Oficial da União, Brasília, DF. Disponível em: <http://www.planalto.gov.br/ccivil_03/leis/19503.htm>.

Carnis, L. e Blais, E. (2013) An assessment of the safety effects of the French speed camera program. Accident Analysis and Prevention, v. 51, p. 301-309.

CONTRAN (1998a) Resolução Contran n 23, de 21 de maio de 1998. Define e estabelece os requisitos mínimos necessários para autorização e instalação de instrumentos eletrônicos de medição de velocidade de operação autônoma, conforme o $§ 2^{\circ}$ do art. 280 do Código de Trânsito Brasileiro. Brasília, DF.

CONTRAN (1998b) Resolução Contran n n $^{\text {79, de }} 19$ de novembro de 1998. Estabelece a sinalização indicativa de fiscalização. Brasília, DF.

CONTRAN (2000a) Resolução Contran n 111, de 24 de fevereiro de 2000. Prorroga o prazo estabelecido no art. $3^{\circ}$ da Resolução n ${ }^{\circ}$ 79/98. Brasília, DF.

CONTRAN (2000b) Resolução Contran n ${ }^{\circ} 118$, de 26 de julho de 2000. Prorroga o prazo estabelecido no art. $3^{\circ}$ da Resolução n ${ }^{\circ}$ 79/98 - CONTRAN. Brasília, DF.

CONTRAN (2001) Resolução Contran n 125, de 14 de fevereiro de 2001. Prorroga o prazo estabelecido no art. $3^{\circ}$ da Resolução n ${ }^{\circ} 79 / 98$ - CONTRAN. Brasília, DF. 
CONTRAN (2002a) Resolução Contran nº 131, de 2 de abril de 2002. Dispõe sobre requisitos técnicos mínimos para fiscalização da velocidade de veículos automotores, elétricos, reboques e semi-reboques, conforme o Código de Trânsito Brasileiro. Brasília, DF.

CONTRAN (2002b) Resolução Contran $n^{\circ}$ 136, de 2 de abril de 2002. Dispõe sobre os valores das multas de infração de trânsito. Brasília, DF.

CONTRAN (2002c) Resolução Contran n 140, de 19 de setembro de 2002. Declara a nulidade da Resolução $n^{\circ}$ 131, de 2 de abril de 2002, e da Deliberação $n^{\circ}$ 034, de 9 de maio de 2002, publicadas, respectivamente, no Diário Oficial da União de 9 e 10 de maio do corrente. Brasília, DF.

CONTRAN (2002d) Resolução Contran n 141, de 3 de outubro de 2002. Dispõe sobre o uso, a localização, a instalação e a operação de aparelho, de equipamento ou de qualquer outro meio tecnológico para auxiliar na gestão do trânsito e dá outras providências. Brasília, DF.

CONTRAN (2003) Resolução Contran $n^{\circ}$ 146, de 27 de agosto de 2003. Dispõe sobre requisitos técnicos mínimos para a fiscalização da velocidade de veículos automotores, reboques e semi-reboques, conforme o Código de Trânsito Brasileiro. Brasília, DF.

CONTRAN (2004a) Resolução Contran n 165, de 10 de setembro de 2004. Regulamenta a utilização de sistemas automáticos não metrológicos de fiscalização, nos termos do $§ 2^{\circ}$ do artigo 280 do Código de Trânsito Brasileiro. Brasília, DF.

CONTRAN (2004b) Resolução Contran n 166, de 15 de setembro de 2004. Aprova as diretrizes da Política Nacional de Trânsito. Brasília, DF.

CONTRAN (2005) Resolução Contran $n^{\circ}$ 174, de 23 de junho de 2005. Altera e esclarece dispositivos da Resolução Contran $n^{\circ}$ 165/04, que trata da regulamentação da utilização de sistemas automáticos não metrológicos de fiscalização, nos termos do $§ 2^{\circ}$ do Artigo 280, do Código de Trânsito Brasileiro. Brasília, DF.

CONTRAN (2006a) Resolução Contran n ${ }^{\circ} 202$, de 25 de agosto de 2006. Regulamenta a Lei no 11.334 de 25 de julho de 2006, que alterou o artigo 218 da 9.503/97, que instituiu o Código de Trânsito Brasileiro. Brasília, DF.

CONTRAN (2006b) Resolução Contran $n^{\circ}$ 214, de 13 de novembro de 2006. Altera o art. $3^{\circ}$ e o Anexo I, acrescenta o art. $5^{\circ}$ A e o Anexo IV na Resolução Contran no 146/03 e dá outras providências. Brasília, DF.

CONTRAN (2007a) Sinalização vertical de advertência. Brasília, DF. (Manual Brasileiro de Sinalização de Trânsito, 2). 
CONTRAN (2007b) Sinalização horizontal. Brasília, DF. (Manual Brasileiro de Sinalização de Trânsito, 3).

CONTRAN (2011) Resolução Contran n 396, de 13 de dezembro de 2011. Dispõe sobre requisitos técnicos mínimos para a fiscalização da velocidade de veículos automotores, reboques e semirreboques, conforme o Código de Trânsito Brasileiro. Brasília, DF.

CONTRAN (2012) Resolução Contran $n^{\circ}$ 404, de 12 de junho de 2012. Dispõe sobre padronização dos procedimentos administrativos na lavratura de Auto de Infração, na expedição de notificação de autuação e de notificação de penalidade de multa e de advertência, por infração de responsabilidade de proprietário e de condutor de veículo e da identificação de condutor infrator, e dá outras providências. Brasília, DF.

CONTRAN (2013a) Resolução Contran n 458, de 29 de outubro de 20013. Altera a Resolução Contran nº 165 , de 10 de setembro de 2004, que regulamenta a utilização de sistemas automáticos não metrológicos de fiscalização, nos termos do $\S 2^{\circ}$ do art. 280 do Código de Trânsito Brasileiro. Brasília, DF.

CONTRAN (2013b) Contran n 471, de 18 de dezembro de 20013. Regulamenta a fiscalização de trânsito por intermédio de videomonitoramento em estradas e rodovias, nos termos do $\S 2^{\circ}$ do artigo 280 do Código de Trânsito Brasileiro. Brasília, DF.

CONTRAN (2014) Sinalização semafórica. Brasília, DF. (Manual Brasileiro de Sinalização de Trânsito, 5). Anexo da Resolução Contran nº 483, de 9 de abril de 2014.

DENATRAN (2004) Portaria Denatran n 16/2004. Estabelece os requisitos específicos mínimos dos sistemas automáticos não metrológicos para a fiscalização das infrações previstas no CTB. Brasília, DF.

DENATRAN (2005) Portaria Denatran $n^{\circ}$ 27/2005. Amplia as infrações que podem ser fiscalizadas com a utilização de sistemas automáticos não metrológicos e estabelece os requisitos específicos mínimos. Brasília, DF.

DENATRAN (2007) Portaria Denatran no 263/2007. Estabelece os requisitos específicos mínimos do sistema automático não metrológico para a fiscalização das seguintes infrações de trânsito previstas no CTB: I Executar operação de retorno em locais proibidos pela sinalização (Art. 206, inciso I); II - Executar operação de conversão à direita ou à esquerda em locais proibidos pela sinalização (Art. 207). Brasília, DF.

DENATRAN (2010a) Portaria Denatran n 870/2010. Estabelece os requisitos específicos mínimos do sistema automático não metrológico para a fiscalização das infrações previstas no artigo 209 do CTB para as seguintes condutas: I - deixar de adentrar às áreas destinadas à pesagem de veículos; II - transpor, sem autorização, bloqueio viário localizado na saída das áreas destinadas à pesagem de veículos. Brasília, DF. 
DENATRAN (2010b) Comitê Nacional de Mobilização pela Saúde, Segurança e Paz no Trânsito. Plano Nacional de Redução de Acidentes e Segurança Viária para a Década 2011-2020. Ministério das Cidades, Brasília, DF.

DENATRAN (2011) Portaria Denatran n 1.113/2011. Altera as portarias DENATRAN no 16/2004, $n^{\circ}$ 263/2007 e $n^{\circ} 870 / 2010$, que estabelecem requisitos mínimos para a fiscalização de diferentes infrações por meio de sistema automático não metrológico de fiscalização de trânsito. Brasília, DF.

DENATRAN (2014) Portaria Denatran $n^{\circ}$ 85/2014. Altera a Portaria DENATRAN nº 16, de 21 de setembro de 2004, para dispensar a elaboração de projeto tipo para cada local fiscalizado com sistema automático não metrológico móvel. Brasília, DF.

Filizola, I. M.; Pelisson, J. C. D. e Silva, P. C. M. (2014) Método para cálculo dos tempos de retardo e permanência definidos na Portaria no 16/2004 do Denatran. Brasília, DF. Não publicado.

Gibbs, J. P. (1979) Assessing the deterrence doctrine: a challenge for the social and behavioral sciences. American Behavioral Scientist, v. 22, n. 6, p. 653-677.

Hallmark, S.; Oneyear, N. e McDonald, T. (2012) Toolbox of countermeasures to reduce red light running. Iowa Department of Transportation Midwest Transportation Consortium. Iowa State University. InTrans Project 10386.

IIHS ([2013?]) Red light running: camera enforcement works to curb this dangerous behavior. Disponível em: <http://www.iihs.org/iihs/topics/t/red-light-running/topicoverview>. Acesso em: 27 set. 2014.

Lum, K. M. e Wong, Y. D. (2003) A before and after study of driver stopping propensity at red light camera intersections. Accident Analysis and Prevention, v. 35, p. 111-120.

McCartt, A. T. e Hu, W. (2014) Effects of red light camera enforcement on red light violations in Arlington County, Virginia. Journal of Safety Research, v. 48, p. 57-62.

Medri, W. (2011) Análise exploratória de dados. Londrina, PR. Curso de especialização latu sensu em estatística.

Ministério da Saúde (2014) Sistema de Informações sobre Mortalidade - SIM - da Secretaria de Vigilância de Saúde. Brasília, DF. Disponível em: 〈http://tabnet.datasus.gov.br/cgi/deftohtm.exe?sim/cnv/ext10uf.def〉. Acesso em: 7 set. 2014.

Pauw, E.; Daniels, S.; Brijs, T.; Hermans, E. e Wets, G. (2014a) An evaluation of the traffic safety effect of fixed speed cameras. Safety Science, v. 62, p. 168-174. 
Pauw, E.; Daniels, S.; Brijs, T.; Hermans, E. e Wets, G. (2014b) To brake or to accelerate? Safety effects of combined speed and red light cameras. Journal of Safety Research, v. 50, p. 59-65.

Pereira, H. C. e Ayala, R. J. L. (2011) Tratamento de trecho crítico com atropelamentos fatais: Via LJ02 Taguatinga/DF. Brasília, DF. Relatório técnico apresentado na disciplina Segurança Viária, do Programa de Mestrado em Transportes da Universidade de Brasília. Não publicado.

Pereira, H. C. e Silva, P. C. M. (2012) Influência do radar no comportamento de condutores em interseções semaforizadas. Anales del XVII Congreso Panamericano de Ingeniería de Tránsito, Transporte y Logística, Santiago.

Pereira, H. C.; Souza, A. C. S.; Gonçalves, A. R.; Silva, L. C. e Margon, P. V. (2013) Custo da externalidade acidente de trânsito no Distrito Federal. Anales del XVI Congreso Chileno de Ingienería de Transporte, Santiago.

Pereira, H. C.; Souza, A. C. S.; Ayala, R. J. L. e Silva, P. C. M. (2014) Análisis de la utilización de display de velocidad en equipos de fiscalización fijos. Anales del XI Congreso de Ingeniería de Transporte, Santander. Disponível em:

http://www.cit2014.unican.es/index.php?option=com_remository\&Itemid=625\&func=startdown\&id=134\&lang= ES>. Acesso em: 3 nov. 2014.

Porter, B. E.; Johnson, K. L. e Bland, J. F. (2013) Turning off the cameras: red light running characteristics and rates after photo enforcement legislation expired. Accident Analysis and Prevention, v. 50, p. 1104-1111.

Pulugurtha, S. S. e Otturu, R. (2014) Effectiveness of red light running camera enforcement program in reducing crashes: evaluation using "before the installation", "after the installation", and "after the termination" data. Accident Analysis and Prevention, v. 64, p. 9-17.

Retting, R. A.; Ferguson, S. A. e Farmer, C. M. (2007) Reducing red light running through longer yellow signal timing and red light camera enforcement: results of a field investigation. Insurance Institute for Highway Safety.

Vanlaar, W.; Robertson, R. e Marcoux, K. (2014) An evaluation of Winnipeg's photo enforcement safety program: results of time series analyses and an intersection camera experiment. Accident Analysis and Prevention, v. 62, p. 238-247.

Vieira, J. L. P. (2003) Questões que envolvem os controladores de velocidade utilizados na fiscalização de trânsito no Brasil. Câmara dos Deputados, Brasília, DF. Estudo de consultoria legislativa.

Yang, Q.; Han, L. D. e Cherry, C. R. (2013) Some measures for sustaining red-light camera programs and their negative impacts. Transport Policy, v. 29, p. 192-198. 
APÊNDICES 


\section{A CONTRAMEDIDAS DE OPERAÇÃO DO SEMÁFORO}

As contramedidas de operação do semáforo são implementadas através de modificação da fase do semáforo, da duração do ciclo ou do intervalo de mudança.

\section{- Aumento do intervalo de amarelo}

Ainda que as referências citadas relacionem a contramedida de engenharia com o "aumento" do intervalo de amarelo, entende-se que a redução das infrações por ASV é afetada pela adoção de valores sem o devido cálculo, que estão abaixo do recomendado.

Até mesmo valores de intervalo de amarelo acima do calculado impactam o atraso na interseção, influenciando a propensão do condutor em avançar o sinal vermelho. Conforme Hallmark, Oneyear e McDonald (2012), os condutores têm expectativas para a duração da luz amarela com base em experiências passadas, e um sinal indevidamente cronometrado pode influenciar um condutor a violar o sinal vermelho.

Bonneson, Zimmerman e Brewer (2002) discorrem que os condutores irão se adaptar a um aumento na duração do amarelo e continuar a avançar a indicação vermelha com a mesma frequência que antes do aumento de amarelo. No entanto, os autores descobriram que um aumento nominal de 0,5 a 1,5 s de amarelo (de tal forma que a duração de amarelo não exceda 5,5 s) irá diminuir a frequência de ASV em 50\%. Os autores concluem que a duração do intervalo de amarelo devidamente cronometrado, baseado na análise de engenharia e na consideração das condições de tráfego, da visibilidade do dispositivo de controle e da distância de visibilidade da interseção, traz benefícios para a redução de infrações por ASV.

Retting, Ferguson e Farmer (2007) mostram que o fornecimento adequado de tempo de sinal amarelo reduz ASV, porém mais tempo de amarelo por si só não elimina a necessidade de uma melhor fiscalização, que pode ser realizada de forma eficaz por câmeras de ASV.

De acordo com Hallmark, Oneyear e McDonald (2012), o intervalo amarelo em um cruzamento deve ter uma duração suficiente para permitir que um veículo possa passar de forma segura através da interseção. O MUTCD (2009 apud HALLMARK, ONEYEAR e McDONALD, 2012) fornece a orientação de que nos intervalos de amarelo deve haver pelo 
menos $3 \mathrm{~s}$ e não mais de $6 \mathrm{~s}$, bem como basear-se na equação de intervalo mínimo de amarelo do ITE, que é dependente da velocidade do veículo e do tempo de reação.

$$
Y=t+\frac{1.47 \times V_{85}}{2(a+G g)}
$$

$\mathrm{Y}=$ duração de amarelo em segundos

$\mathrm{t}=$ tempo de reação $=1 \mathrm{~s}$

$\mathrm{V}_{85}=$ velocidade de 85 percentil em milhas/hora

$\mathrm{a}=$ desaceleração $=10$ pés $/ \mathrm{s}^{2}$ (equivale a $3 \mathrm{~m} / \mathrm{s}^{2}$ no sistema métrico)

$\mathrm{G}=$ greide em pés/pés (sendo “+” em rampas ascendentes e “-” em rampas descendentes)

$\mathrm{g}=$ aceleração da gravidade $=32,2$ pés $/ \mathrm{s}^{2}$ (equivale a $9,8 \mathrm{~m} / \mathrm{s}^{2}$ no sistema métrico)

O presente trabalho avaliou o tempo de amarelo das interseções estudadas com base no manual Sinalização semafórica (CONTRAN, 2014).

\section{- Aumento do intervalo de vermelho geral}

O intervalo de vermelho geral veicular é o intervalo de tempo entre o final do amarelo de um estágio e o início do verde do próximo estágio.

Seyfried (2004 apud YANG, HAN e CHERRY, 2013) relatou que um intervalo de vermelho geral e seu comprimento não influenciam as decisões dos condutores sobre o ASV. Awadallah (2009 apud YANG, HAN e CHERRY, 2013) descobriu que os intervalos de vermelho geral não são necessariamente uma solução para ASV, especialmente quando os condutores chegam a esperar um incremento adicional de segurança e tentam abusar dessa medida. Na mesma linha, Bonneson, Zimmerman e Brewer (2002) ressaltam a importância do intervalo de vermelho geral para a segurança da interseção, porém não classificam o aumento do intervalo de vermelho geral como contramedida de redução de infrações.

A disposição dos elementos de sustentação do semáforo na via e o uso de pestanas, de forma a impedir a visualização do semáforo da via transversal pelos condutores que irão receber a indicação verde, pode influenciar a decisão do condutor em avançar o veículo no intervalo de vermelho geral. A fiscalização eletrônica é um elemento eficaz para inibir esse tipo de comportamento. 
O presente trabalho avaliou o tempo de vermelho geral das interseções estudadas com base no manual Sinalização semafórica (CONTRAN, 2014).

\section{- Entreverdes}

Para semáforos veiculares, o entreverdes compõe-se do intervalo de amarelo seguido, sempre que possível, do intervalo de vermelho geral. No caso de grupos focais de pedestres, consiste no intervalo de vermelho intermitente seguido do intervalo de vermelho geral.

De acordo com o manual Sinalização semafórica (CONTRAN, 2014), a função do entreverdes veicular é assegurar a travessia da interseção por veículos que, ao receberem a indicação amarela, se encontrem a uma distância da linha de retenção que seja insuficiente para parar com segurança. O tempo de entreverdes deve ser suficiente para que o veículo possa tanto percorrer a distância até a linha de retenção como concluir a travessia abandonando a área de conflito, antes que os veículos ou pedestres dos movimentos conflitantes recebam direito de passagem.

O manual Sinalização semafórica (CONTRAN, 2014) calcula o tempo de entreverdes necessário para atender o veículo que estiver na posição mais desfavorável no instante em que seu intervalo verde é encerrado.

$$
t_{\text {ent }}=t_{p r}+\frac{v}{2\left(a_{a d}+i g\right)}+\frac{d_{2}+c}{v}
$$

em que:

$t_{\text {ent }}=$ tempo de entreverdes para o grupo focal de veículos (em segundos);

$t_{p r}=$ tempo de percepção e reação do condutor (em segundos);

$v=$ velocidade do veículo, em $\mathrm{m} / \mathrm{s}$;

$a_{a d}=$ máxima taxa de frenagem admissível em via plana, em $\mathrm{m} / \mathrm{s}^{2}$;

$i=$ inclinação da via na aproximação, sendo "+” em rampas ascendentes e "-” em rampas descendentes $(\mathrm{m} / \mathrm{m})$;

$g=$ aceleração da gravidade $\left(9,8 \mathrm{~m} / \mathrm{s}^{2}\right)$;

$d_{2}=$ extensão da trajetória do veículo entre a linha de retenção e o término da área de conflito (em metros);

$c=$ comprimento do veículo (em metros). 
Na composição do tempo de entreverdes, as duas primeiras parcelas fornecem o tempo de amarelo $\left(t_{a m}\right)$ e a última parcela, o tempo de vermelho geral $\left(t_{v g}\right)$.

Nesse caso, esses tempos serão calculados segundo as equações 3 e 4,

$$
t_{a m}=t_{p r}+\frac{v}{2\left(a_{a d}+i g\right)}
$$

$\mathrm{e}$

$$
t_{v g}=\frac{d_{2}+c}{v}
$$

em que:

$\mathrm{v}=$ velocidade regulamentada da via, expressa $\mathrm{em} \mathrm{m} / \mathrm{s}$.

Segundo o manual Sinalização semafórica (CONTRAN, 2014), usualmente são adotados os seguintes valores para as grandezas envolvidas:

$\mathrm{t}_{\mathrm{pr}}=1 \mathrm{~s}$

$\mathrm{a}_{\mathrm{ad}}=3 \mathrm{~m} / \mathrm{s}^{2}$;

$\mathrm{c}=5 \mathrm{~m}$ (onde o fluxo é predominantemente constituído por automóveis).

Em situações em que o local apresente condições particulares de topografia ou composição do tráfego, esses valores devem ser substituídos por outros levantados diretamente em campo. $\mathrm{O}$ vermelho geral do estágio veicular deve ser acrescido de, no mínimo, $1 \mathrm{~s}$ sempre que o estágio subsequente atender travessia de pedestres.

Cabe ressaltar que o manual Sinalização semafórica (CONTRAN, 2014) traz o cuidado de esclarecer os critérios de arredondamento, em que a soma do valor calculado de entreverdes deve ser arredondada para cima, e não cada uma das parcelas de amarelo e de vermelho geral, sob o risco de elevar excessivamente o valor total.

Observa-se também que as equações 1 (MUTCD) e 2 (Contran) diferem no que tange às escalas do sistema inglês e do sistema métrico, respectivamente, e no fato de que o MUTCD (2009 apud HALLMARK, ONEYEAR e McDONALD, 2012) utiliza como velocidade o 85 percentil, ao passo que o manual Sinalização semafórica (CONTRAN, 2014) recomenda a 
velocidade regulamentada da via. A constante 1,47 da Equação 1 apenas transforma milhas/hora para pés/segundo.

\section{- Fornecer extensão do verde (controle atuado)}

Conforme o manual Sinalização semafórica (CONTRAN, 2014), extensão de verde é um elemento da programação do tipo de controle atuado e é o intervalo que se acresce ao tempo de verde veicular quando um veículo é detectado durante o verde mínimo veicular ou durante a extensão de verde anterior.

A extensão do verde pode reduzir o número de infrações ao prolongar a mudança para o amarelo enquanto houver veículos na aproximação, até o limite de verde máximo. De acordo com Zegeer e Deen (1978 apud BONNESON, ZIMMERMAN e BREWER, 2002), a extensão do verde tem o potencial de reduzir a frequência de ASV em $65 \%$.

O manual Sinalização semafórica (CONTRAN, 2014) sugere que o verde máximo seja 50\% maior que o tempo de verde que seria programado se o controle fosse feito por sinalização semafórica de tempo fixo.

Segundo Hallmark, Oneyear e McDonald (2012), se um veículo for detectado dentro da zona de dilema, o intervalo de verde é aumentado para permitir que o veículo passe através da interseção com segurança. Os autores observam que a extensão do verde é limitada e, no entanto, os condutores que sempre se aproveitam desse recurso ainda podem violar o sinal.

\section{- Melhorar a coordenação semafórica}

A coordenação semafórica tem como objetivo melhorar o desempenho da circulação de veículos e/ou pedestres em uma rede.

Van der Horst e Wilmink (1986 apud BONNESON, ZIMMERMAN e BREWER, 2002) observaram que condutores que se aproximam de um cruzamento dentro de um pelotão enquanto o verde é exibido possuem a expectativa de que a indicação permanecerá verde o tempo suficiente para atravessarem a interseção. Pelotão é um grupo de veículos que se forma durante a retenção dos veículos no intervalo de vermelho e que inicia a circulação de modo compacto, tendendo a se dispersar à medida que os veículos se afastam da linha de retenção. 
Considerando-se a dispersão dos veículos, a coordenação semafórica pode controlar a chegada da parcela de um pelotão próxima ao fim do intervalo de verde, contribuindo para a redução da frequência de ASV. Pode também reduzir o atraso e o número de paradas ao longo de um conjunto de interseções e evitar o bloqueio de interseções próximas por filas com extensão superior à capacidade do trecho viário entre elas.

O manual Sinalização semafórica (CONTRAN, 2014) cita alguns aspectos que podem comprometer a eficácia da coordenação semafórica, quando não observados:

- Presença de estacionamento e/ou pontos de ônibus nos arredores da aproximação, com impacto significativo sobre o fluxo de saturação correspondente;

- Dispersão dos pelotões liberados em uma interseção ao longo do percurso até a linha de retenção da interseção a jusante, levando em conta até mesmo a composição do tráfego e a presença de estacionamento e/ou pontos de ônibus nesse percurso;

- Diferença entre os tempos de verde que atendem à mesma corrente de tráfego em interseções sucessivas;

- Presença de fila na aproximação a jusante decorrente de volumes significativos de movimentos de conversão e/ou de entradas e saídas intermediárias de veículos.

Bonneson, Zimmerman e Brewer (2002) descobriram que o ASV é mais frequente nos cruzamentos com pelotões que chegam perto no fim da indicação verde. Por isso, recomendam que, quando essa situação não pode ser evitada, um ciclo mais longo pode ser utilizado com o plano de coordenação para minimizar a frequência do ASV.

\section{- Melhorar a operação do semáforo}

Respeitadas as condições de segurança de veículos e pedestres e observada a coordenação semafórica quando for o caso, as melhorias na operação do semáforo que diminuem atrasos são susceptíveis de reduzir as infrações por ASV. Bonneson, Zimmerman e Brewer (2002) apontam que alterar o comprimento de um ciclo de $60 \mathrm{~s}$ para $120 \mathrm{~s}$ reduz em $50 \%$ o número de vezes em que a indicação amarela do semáforo é apresentada, diminuindo a exposição do condutor. Hallmark, Oneyear e McDonald (2012) afirmam que a otimização de um semáforo pode reduzir atrasos e aumentar a capacidade do cruzamento, diminuindo a frustação do condutor. 
De acordo com o manual Sinalização semafórica (CONTRAN, 2014), a coordenação semafórica deve ser avaliada continuamente em razão do caráter dinâmico do trânsito, e as principais medidas de desempenho para avaliação são: fila máxima, velocidade média, número de paradas, atraso, consumo de combustível, emissão de poluentes e custo monetário.

\section{B CONTRAMEDIDAS DE INFORMAÇÕES AO CONDUTOR}

Referem-se a melhorias para a exibição do semáforo ou o fornecimento de informações prévias para o condutor sobre a existência de um semáforo à frente.

\section{- Adequar a configuração do elemento de sustentação do semáforo}

Conforme o manual Sinalização semafórica (CONTRAN, 2014), o tipo de elemento de sustentação do semáforo depende de fatores como necessidade de projeção sobre a via, características geométricas do local, dimensionamento da carga a ser suportada, velocidade dos ventos, condições de visibilidade, composição do tráfego e largura das vias.

Os tipos de elementos de sustentação são coluna, braço projetado, pórtico e cordoalha, visualizados na Figura $1(a, b, c$ e $d)$, respectivamente.

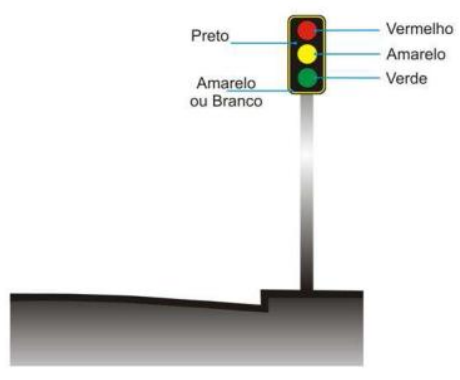

(a) Coluna

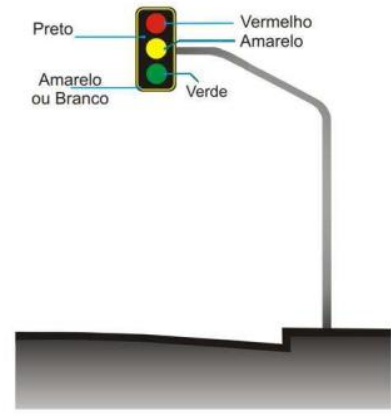

(b) Braço projetado

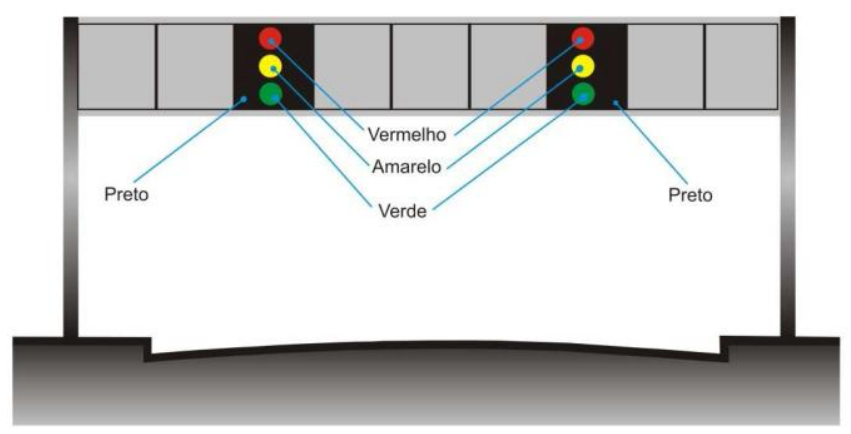

(c) Pórtico 


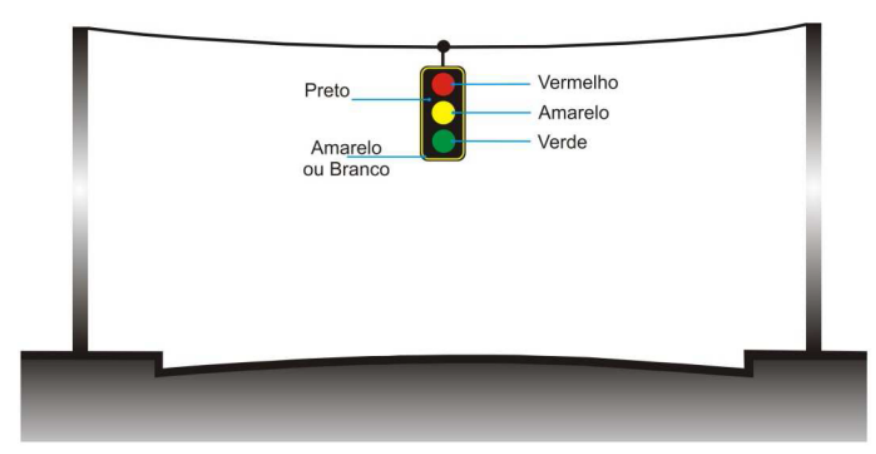

(d) Cordoalha

Figura 1: Tipos de elementos de sustentação de semáforos

Fonte: CONTRAN (2014).

Rodegerdts et al. (2004 apud HALLMARK, ONEYEAR e McDONALD, 2012) apontam que a visibilidade de sinais projetados (braço, pórtico e cordoalha) é menos frequentemente prejudicada por veículos de grande porte em comparação com a coluna, impactando a quantidade de infrações e de acidentes.

Com relação ao posicionamento dos elementos de sustentação, o manual Sinalização semafórica (CONTRAN, 2014) cita dois padrões, antes e depois da via transversal, com características operacionais próprias, e recomenda a adoção de um único padrão para um mesmo município. Situações excepcionais podem surgir por motivos de segurança ou de situações críticas de fluidez. O Quadro 1 permite visualizar diversas características dos semáforos posicionados antes e depois da via transversal.

No Quadro 1 é possível observar que o posicionamento do semáforo após a via transversal melhora a visibilidade em todos os tópicos. Ao mesmo tempo, medidas de fiscalização podem ser necessárias para inibir comportamentos de risco de condutores que avançam o sinal vermelho deliberadamente.

O uso de pestanas pode colaborar para reduzir a intervisibilidade de focos dirigidos a correntes de tráfego conflitantes, além de melhorar a condição de contraste pela redução de incidência da luz solar sobre a lente. 
Quadro 1: Características da posição do semáforo em relação à via transversal

\begin{tabular}{|c|c|c|}
\hline Tópico & Antes & Depois \\
\hline $\begin{array}{l}\text { Parada na } \\
\text { linha de } \\
\text { retenção }\end{array}$ & $\begin{array}{l}\text { Induz o condutor a parar o veículo antes da linha de } \\
\text { retenção em virtude da condição de visualização do } \\
\text { semáforo. }\end{array}$ & $\begin{array}{l}\text { Diante da facilidade de visualização dos grupos focais } \\
\text { posicionados após a interseção, pode haver desrespeito à faixa } \\
\text { de retenção e invasão da faixa de pedestres pelos veículos. }\end{array}$ \\
\hline $\begin{array}{l}\text { Transposição } \\
\text { da interseção }\end{array}$ & Sem informação da indicação luminosa do semáforo. & Com informação da indicação luminosa do semáforo. \\
\hline $\begin{array}{l}\text { Travessia de } \\
\text { pedestres }\end{array}$ & $\begin{array}{l}\text { Induz o condutor a parar o veículo antes da faixa de } \\
\text { travessia de pedestres em virtude da condição de } \\
\text { visualização do semáforo. }\end{array}$ & $\begin{array}{l}\text { Pedestres geralmente conseguem visualizar a operação da } \\
\text { sinalização semafórica por meio dos grupos veiculares e } \\
\text { compreender quando as correntes de tráfego são interrompidas. }\end{array}$ \\
\hline $\begin{array}{l}\text { Visibilidade } \\
\text { do semáforo }\end{array}$ & $\begin{array}{l}\text { Reduz os riscos de saída antecipada dos veículos em } \\
\text { razão da dificuldade de visualização do semáforo da via } \\
\text { transversal. }\end{array}$ & $\begin{array}{l}\text { Pode haver saída antecipada dos veículos em razão da } \\
\text { possibilidade de visualização do semáforo da via transversal. }\end{array}$ \\
\hline $\begin{array}{l}\text { Quantidade de } \\
\text { material }\end{array}$ & $\begin{array}{l}\text { Necessidade de implantar semáforos adicionais para que } \\
\text { os condutores possam visualizar os focos a curta } \\
\text { distância. Em determinadas situações, a implantação de } \\
\text { semáforos para pedestres é necessária em razão da } \\
\text { dificuldade que os pedestres têm para visualizar a } \\
\text { indicação dos veículos. }\end{array}$ & $\begin{array}{l}\text { Geralmente não é necessário implantar semáforos veiculares } \\
\text { adicionais para a visibilidade dos focos a curta distância. }\end{array}$ \\
\hline $\begin{array}{l}\text { Caixa de } \\
\text { acumulação } \\
\text { de veículos }\end{array}$ & $\begin{array}{l}\text { Quando pequenas podem não comportar a quantidade de } \\
\text { veículos armazenados, uma vez que é necessário manter } \\
\text { distância mínima de visibilidade entre a linha de focos e a } \\
\text { retenção. }\end{array}$ & $\begin{array}{l}\text { A caixa de acumulação pode iniciar no limite da área de conflito } \\
\text { da interseção, maximizando a quantidade de veículos } \\
\text { acumulados. }\end{array}$ \\
\hline Interferências & $\begin{array}{l}\text { A visualização clara da linha de focos em coluna simples } \\
\text { pode ser prejudicada por interferências laterais, tais como } \\
\text { postes de energia elétrica e árvores. }\end{array}$ & $\begin{array}{l}\text { A visualização clara da linha de focos em coluna simples é } \\
\text { menos prejudicada por interferências laterais, tais como postes } \\
\text { de energia elétrica e árvores. }\end{array}$ \\
\hline
\end{tabular}

Fonte: Adaptado de CONTRAN (2014). 


\section{- Utilizar fonte de luz LED}

As fontes de luz usualmente utilizadas são: lâmpada incandescente com filamento reforçado; lâmpada halógena; lâmpada de LEDs (Light Emitting Diode) ou diodos emissores de luz.

Conforme Hallmark, Oneyear e McDonald (2012), um módulo de semáforo de diodo emissor de luz consiste de pequenas luzes individuais LED, que pode ser utilizado para substituir as lâmpadas incandescentes tradicionais com o objetivo de melhorar a visibilidade do sinal.

\section{- Aumentar a conspicuidade do sinal}

Bonneson, Zimmerman e Brewer (2002) citam duas contramedidas para melhorar a conspicuidade do semáforo: luz estroboscópica e anteparo.

De acordo com Bonneson, Zimmerman e Brewer (2002), a luz estroboscópica é uma barra horizontal ou bulbo em forma de auréola posicionado no meio da lente de sinal vermelho, que pisca uma luz branca em torno de sessenta vezes por minuto enquanto a indicação de vermelho está acesa. Cottrell (1995 apud BONNESON, ZIMMERMAN e BREWER, 2002) coletou dados sobre acidentes durante três anos antes e três anos após a instalação das luzes estroboscópicas em seis interseções na Virgínia, nos Estados Unidos. Apesar de encontrar uma redução global em acidentes em ângulo reto, o pesquisador percebeu uma variação entre os locais de estudo, o que impossibilitou definir a eficácia na redução de acidentes.

Conforme o manual Sinalização semafórica (CONTRAN, 2014), anteparo é o painel que emoldura o grupo focal com o objetivo de melhorar a visibilidade em relação à incidência solar e/ou destacar a sinalização da paisagem urbana. Obrigatório em semáforo instalado em suporte projetado, o anteparo é opcional em semáforo instalado em coluna simples.

Polanis (2002 apud BONNESON, ZIMMERMAN e BREWER, 2002) investigou o efeito do uso de anteparos na frequência de acidentes em seis interseções, concluindo que acidentes em ângulo reto foram reduzidos em 32\%. Hallmark, Oneyear e McDonald (2012) destacam a importância do uso de anteparo em tráfego no sentido leste-oeste durante o nascer e o pôr do sol. De acordo com o MUTCD (2009 apud HALLMARK, ONEYEAR e McDONALD, 2012), uma tira retrorrefletiva amarela com largura de uma a três polegadas pode ser colocada ao longo do perímetro da face do anteparo para projetar uma aparência retangular à noite. 
- Aumentar o tamanho da lente e luzes vermelhas repetidas

Conforme o manual Sinalização semafórica (CONTRAN, 2014), a dimensão das lentes é de $200 \mathrm{~mm}$ ou $300 \mathrm{~mm}$, podendo ser configurada com $200 \mathrm{~mm}$ para amarelo e verde e $300 \mathrm{~mm}$ para vermelho.

De acordo com o MUTCD (2009 apud HALLMARK, ONEYEAR e McDONALD, 2012), todos os novos semáforos são obrigados a ter lentes com dimensões de doze polegadas $(304,8$ $\mathrm{mm})$ e não mais que oito polegadas $(203,2 \mathrm{~mm})$ para o vermelho.

Bonneson, Zimmerman e Brewer (2002) incluem como medida para redução de infrações a adição de uma segunda indicação de vermelho. Polanis (2002 apud BONNESON, ZIMMERMAN e BREWER, 2002) investigou três interseções na cidade de Winston-Salem, na Carolina do Norte, e descobriu que o aumento do tamanho da lente para doze polegadas, o acréscimo de focos semafóricos suplementares e de uma segunda indicação de vermelho influenciaram a redução de colisões em ângulo reto em todas as três interseções, variando entre $33 \%$ e $47 \%$.

\section{- Adicionar foco semafórico}

Segundo Hallmark, Oneyear e McDonald (2012), para diminuir infrações por ASV, um foco semafórico por faixa de trânsito pode ser adicionado para melhorar a visibilidade. De acordo com o MUTCD (2009 apud HALLMARK, ONEYEAR e McDONALD, 2012), no mínimo dois focos semafóricos devem ser instalados nas vias principais, conforme a Tabela 1.

Tabela 1: Número mínimo recomendado de focos semafóricos para aproximações com velocidade regulamentada ou 85 percentil de 45 milhas/hora (aproximadamente $72 \mathrm{~km} / \mathrm{h}$ ) ou maior

\begin{tabular}{c|c|c}
\hline $\begin{array}{c}\text { Número de faixas de } \\
\text { trânsito da aproximação }\end{array}$ & $\begin{array}{c}\text { Número mínimo de focos } \\
\text { semafóricos por } \\
\text { aproximação }\end{array}$ & $\begin{array}{c}\text { Número mínimo de focos } \\
\text { semafóricos em suporte } \\
\text { projetado na aproximação }\end{array}$ \\
\hline 1 & 2 & 1 \\
2 & 2 & 1 \\
3 & 3 & $2^{*}$ \\
4 ou mais & 4 ou mais & $3^{*}$ \\
\hline
\end{tabular}

*Se praticável, todos os focos semafóricos deverão estar em suporte projetado.

Fonte: Adaptado de MUTCD (2009 apud HALLMARK, ONEYEAR e McDONALD, 2012). 
O manual Sinalização semafórica (CONTRAN, 2014) alerta que a quantidade e o posicionamento de grupos focais devem garantir a visibilidade em todas as faixas de pelo menos um grupo focal, tanto do condutor parado diante da linha de retenção como do condutor de veículo em movimento, prevendo-se a possibilidade de queima de uma lâmpada (deve-se adotar no mínimo dois grupos focais por aproximação ou implantar pelo menos um grupo focal com dois focos vermelhos).

\section{- Adicionar placa de advertência de semáforo à frente}

A placa A-14 - Semáforo à frente visa a advertir o condutor do veículo sobre a existência de sinalização semafórica de regulamentação adiante. Deve ser utilizada em situações de difícil percepção ou que possam comprometer a segurança dos usuários da via, tais como antes de semáforo localizado em posição que não obedeça às condições mínimas de visibilidade, necessárias para a percepção, reação e manobra do condutor, e após curvas horizontais ou verticais, conforme o manual Sinalização vertical de advertência (CONTRAN, 2007a).

Nos Estados Unidos, Polanis (2002 apud BONNESON, ZIMMERMAN e BREWER, 2002) revela que o sinal de advertência de semáforo à frente pode vir acompanhado por luzes piscantes para reforçar a detecção da sinalização pelo condutor. $\mathrm{O}$ autor avaliou a eficácia da sinalização com piscante em onze cruzamentos, constatando redução de $44 \%$ de acidentes em ângulo reto.

Conforme o MUTCD (2009 apud HALLMARK, ONEYEAR e McDONALD, 2012), o sinal semafórico à frente deve estar localizado antes da interseção com base na velocidade de aproximação.

\section{- Usar alerta antecipado para o fim do verde (ou início de amarelo)}

Para constar aqui apenas a título de informação, uma vez que não há regulamentação no Brasil a esse respeito, o alerta antecipado para o fim do verde (ou início de amarelo), de acordo com Bonneson, Zimmerman e Brewer (2002), consiste na indicação de verde piscante por vários segundos antes do início do amarelo. Essa medida já é adotada em países como México e Israel. 
Messer et al. (2004 apud HALLMARK, ONEYEAR e McDONALD, 2012) verificaram uma redução em cerca de $40 \%$ no número de infrações com o uso do sistema de alerta antecipado no final da fase verde. Mahalel e Prashker (1987 apud BONNESON, ZIMMERMAN e BREWER, 2002) constataram que essa técnica pode aumentar a frequência de colisões traseiras em razão da indecisão do condutor.

\section{CONTRAMEDIDAS DE MELHORIA FÍSICA}

Inclui um grupo de modificações substanciais para o cruzamento que se destinam a resolver graves problemas de segurança ou de funcionamento.

\section{- Remoção de semáforos desnecessários}

Segundo Bonneson, Zimmerman e Brewer (2002), as condições do trânsito que justificaram a semaforização de um cruzamento podem não existir mais, levando os condutores a pensar que o semáforo é desnecessário e, consequentemente, a desrespeitá-lo. Retting et al. (1998 apud BONNESON, ZIMMERMAN e BREWER, 2002) avaliaram o impacto da remoção de semáforo em 199 interseções na Filadélfia e descobriram que os acidentes diminuíram 24\%.

De acordo com o manual Sinalização semafórica (CONTRAN, 2014), antes de decidir pela implantação da sinalização semafórica, o órgão de trânsito deve avaliar sua efetiva necessidade, considerando a viabilidade de adoção de outras medidas alternativas, tais como:

a) definição da preferência de passagem;

b) remoção de interferências que prejudiquem a visibilidade;

c) melhoria na iluminação;

d) adequação das sinalizações horizontal e vertical;

e) redução das velocidades nas aproximações;

f) adequação na geometria;

g) proibição de estacionamento;

h) implantação de refúgios para pedestres;

i) alteração de circulação;

j) inversão da preferência de passagem;

k) implantação de minirrotatórias;

1) direcionamento dos pedestres para locais de travessia seguros;

m) reforço da sinalização de advertência. 
Não satisfeitas as condições de semaforização do cruzamento, a implantação não justificada apresenta consequências que causam prejuízos ao desempenho e à segurança do trânsito, tais como: aumento de ocorrência de acidentes de trânsito; imposição de atrasos excessivos; indução ao desrespeito à sinalização em virtude da ociosidade na operação; descrédito em relação à sinalização; gastos desnecessários de recursos públicos.

Dessa forma, o estudo para definir a necessidade e a avaliação da eficácia da implantação da sinalização semafórica deve preceder a opção pela instalação de EFE para ASV. Ou seja, a opção pela implantação da fiscalização eletrônica pressupõe que houve estudo e que é adequada a escolha pelo tipo de controle por semáforo.

No caso de decisão referente à remoção da sinalização semafórica, o manual Sinalização semafórica (CONTRAN, 2014) apresenta as atividades a serem realizadas em sequência: estudo técnico; avaliação prática da operação sem sinalização semafórica; tomada de decisão.

\section{- Aumentar capacidade com faixa de tráfego adicional}

Nos casos em que há congestionamento e as filas de veículos não são totalmente servidas no final da fase, condutores continuam a entrar na interseção durante vários segundos depois do início do sinal vermelho. Os condutores nessa situação estão motivados a avançar a indicação do vermelho pelo desejo de evitar o atraso associado com a espera para a próxima indicação de verde.

Conforme Bonneson, Zimmerman e Brewer (2002), em alguns casos as mudanças no faseamento do semáforo podem melhorar a situação de atrasos, porém o aumento da capacidade na forma de faixas de tráfego adicionais é muitas vezes a única solução viável.

\section{- Considerar projeto de rotatória para a interseção}

Uma opção para o controle do cruzamento, que pode ser entendida como parte da contramedida de remoção de semáforos desnecessários, a rotatória apresenta vantagens de pequenos ângulos de entrada e baixas velocidades na aproximação. Isso pode eliminar acidentes graves em ângulo e em conversão à esquerda, consequências das violações de ASV. 


\section{- Melhorar distância de visibilidade do semáforo}

Restrições de distância de visibilidade são muitas vezes causadas por curvatura acentuada, horizontal ou vertical, ou pela folhagem das árvores ou outros objetos adjacentes à via. Veículos estacionados ao lado das faixas de tráfego também podem obstruir a visão do condutor quando grupos focais são instalados em colunas simples.

Hallmark, Oneyear e McDonald (2012) revelam que uma distância de visibilidade deficiente pode contribuir para a maior frequência de ASV, quando os condutores não têm tempo suficiente para reagir para sinalizar mudanças. Melhorias podem ser realizadas com a remoção de objetos, adequação dos grupos focais dentro do cone de visão dos condutores e, em casos que exigem a alocação de mais recursos, adequação da geometria das curvas horizontal e/ou vertical.

Conforme Bonneson, Zimmerman e Brewer (2002), transitar em segurança no trecho curvo pode envolver a atenção prioritária do condutor ao monitoramento da indicação do semáforo, podendo acarretar frequentes ocorrências de ASV.

De acordo com o manual Sinalização semafórica (CONTRAN, 2014), os semáforos (grupos focais) de uma aproximação devem ser visíveis ao condutor de veículos motorizados sob duas condições:

- Quando o veículo está em movimento de aproximação de local semaforizado "visibilidade a distância" -, que considera o campo visual do condutor e a sua velocidade de aproximação, devendo garantir o tempo necessário para o condutor perceber a mudança de sinal, reagir a ela e parar o veículo antes da linha de retenção de forma segura, denominada distância de visibilidade de parada.

- Quando o veículo está parado na linha de retenção - "visibilidade a partir da linha de retenção" -, que depende do atendimento de duas condições: distância do grupo focal à linha de retenção e ângulo entre o eixo de cada aproximação e a linha de visada ao grupo focal, que deve ser menor ou igual a vinte graus.

A metodologia para o cálculo da distância de visibilidade está disponível no manual Sinalização semafórica (CONTRAN, 2014). 


\title{
D FORMULÁRIO DE INSPEÇÃO DE CAMPO
}

\author{
INFORMAÇÃO DA LOCALIZAÇÃO
}

Identificação da Interseção: com

Nome da Aproximação Sentido Principal

\section{PARTE 1. VERIFICAR A VISIBILIDADE DO SEMÁFORO}

Elemento de sustentação: ( ) Cordoalha ( ) Braço Projetado （）Coluna （）Pórtico

Distância de Visibilidade para o Semáforo: metros

Requer sinal de alerta antecipado? ( ) S ( ) N Sinal de alerta presente: ( ) S ( ) N Há objeto bloqueando a visibilidade do semáforo? ( ) S ～～～～N Se sim, descrever A face do sinal pode ser vista por outras aproximações? ( ) S ( ) N S sim, esses sinais tem visores, protetores ou lentes programáveis? ( ) S ( ) $\mathrm{N}$

\section{PARTE 2. VERIFICAR A CONSPICUIDADE DO SEMÁFORO}

Poderia a poluição visual diminuir a visibilidade do semáforo? ( ) S ( ) N

As indicações do semáforo são confusas? ( ) S ( ) N

Se sim, explique:

Anteparos estão presentes? ( ) S ( ) N

Outras medidas para reduzir o brilho são necessárias? ( ) $\mathrm{S}$ （ ) N

Tipo de lâmpadas do semáforo: ( ) Incandescente （ ) LEDs （ ) Halógena

Tamanho da lente do semáforo está adequado?

Tamanho da lente de sinal vermelho: ( ) $20 \mathrm{~cm} \quad$ ( ) $30 \mathrm{~cm}$

Distância da linha de retenção para o semáforo: $\mathrm{m}$

O tamanho está adequado? ( ) S （） N

Número de focos semafóricos está adequado?

Número total de focos do semáforo para o maior movimento:

Número total de faixas para o maior movimento:

O número existente está adequado? ( ) S （） N

Posição dos focos do semáforo está adequada? ( ) S （）N

\section{PARTE 3. VERIFICAR OS PARÂMETROS DE CONTROLE DO SEMÁFORO}

Greide (como decimal) $i=$ (subida é positivo)

Velocidade regulamentada da via $v=$ $\mathrm{m} / \mathrm{s}$

Largura da rua transversal $\mathrm{W}=$ $\mathrm{m}$

Comprimento do veículo conforme fluxo observado $c=$ m 
Extensão da trajetória do veículo entre a linha de retenção e o término da área de conflito, em metros $d_{2}=$ $m$

Calcular o entreverdes necessário para esta aproximação usando prática da agência ou a seguinte equação:

$$
t_{e n t}=t_{p r}+\frac{v}{2\left(a_{a d}+i g\right)}+\frac{d_{2}+c}{v}
$$

\begin{tabular}{c|c|c|c|c}
\hline & Valor Real & Valor Calculado & \multicolumn{2}{|c}{ O existente está adequado? } \\
\hline $\begin{array}{c}\text { Intervalo de } \\
\text { Amarelo }\end{array}$ & & $\mathrm{S}$ & $\mathrm{N}$ \\
\hline $\begin{array}{c}\text { Intervalo de } \\
\text { Vermelho Geral }\end{array}$ & & $\mathrm{S}$ & $\mathrm{N}$ \\
\hline
\end{tabular}

\section{PARTE 4. VERIFICAR OUTROS FATORES}

Localização horizontal está adequada? ( ) S （ ） N

Condições do pavimento na aproximação: ( ) Adequado ( ) Liso ( ) Severamente esburacado

Deve ser conduzido estudo para sinal de alerta? ( ) S ( ) N Outras preocupações:

\section{PARTE 5. IDENTIFICAR CONTRAMEDIDAS PROMISSORAS}

Deficiência de visibilidade

( ) Instalar focos semafóricos adicionais

( ) Mudar o elemento de sustentação do semáforo

( ) Instalar placa de sinalização de semáforo à frente

( ) Instalar luzes de alerta antecipadas

( ) Remover/realocar obstrução de sinal

( ) Instalar anteparos e pestanas

( ) Outros:

Deficiência de conspicuidade

( ) Adicionar foco semafórico para obter um por faixa

( ) Substituir com lentes tipo LED

( ) Substituir com tamanho de $30 \mathrm{~cm}$

( ) Instalar sinal vermelho com dois focos

( ) Instalar/melhorar anteparo

( ) Instalar bandas sonoras sobre a aproximação

( ) Outros:

Deficiência na operação do tempo do semáforo

( ) Alterar o intervalo de amarelo 

( ) Adicionar/alterar intervalo de vermelho geral
( ) Melhorar programação semafórica
( ) Melhorar coordenação semafórica
( ) Outros:

Melhorias físicas
( ) Avaliar necessidade do semáforo
( ) Considerar rotatória ou projeto inovador
( ) Melhorar condição do pavimento
( ) Outros:

Inspecionado por:

Data: 